http://kitaibelia.unideb.hu/

ISSN 2064-4507 (Online) • ISSN 1219-9672 (Print)

(C) Department of Botany, University of Debrecen, Hungary

26(1): 77-84.; 2021

DOI: $10.17542 /$ kit.26.77

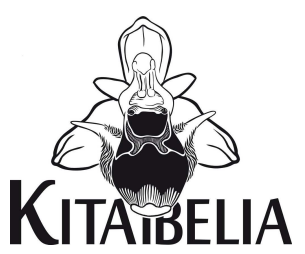

\title{
Pótlások Magyarország edényes növényfajainak elterjedési atlaszához XII.
}

\author{
KeVEy Balázs ${ }^{1 *}$, Demeter László2 ${ }^{2}$ LendVAi Gábor ${ }^{3}$, MolnÁr Attila $^{4}$, \\ PAPP László ${ }^{5}$ \& URBÁN Sándor 6
}

(1) Pécsi Tudományegyetem TTK Ökológiai Tanszék, H-7624 Pécs, Ifjúság útja 6.; *keveyb@gamma.ttk.pte.hu

(2) Hortobágyi Nemzeti Park Igazgatóság, H-4024 Debrecen, Sumen u. 2.

(3) H-7000 Sárbogárd, Tompa Mihály u. 38/C.

(4) H-4027 Debrecen, Domokos u. 8.

(5) Debreceni Egyetem Botanikus kert, H-4032 Debrecen, Egyetem tér 1.

(6) H-5000 Szolnok, Barátság út 11.

\section{Contributions to the Atlas Florae Hungariae XII.}

\begin{abstract}
In this work, we report data supplementing the Distribution atlas of vascular plants of Hungary. Altogether 1325 data of 460 vascular plant taxa are reported as contributions to 149 quadrants in the Central European Flora Mapping grid system. The new stands of Phegopteris connectilis (NW foothills of the Vértes Hills), Sternbergia colchiciflora and Corydalis solida (DanubeTisza Interfluve), Euphorbia angulata and Potentilla alba (Nyírség) are particularly noteworthy. In addition, new stands of numerous rare or scattered species are also listed: Allium paniculatum, $A$. sphaerocephalon, Asplenium adiantum-nigrum, Botrychium lunaria, Bulbocodium vernum, Clematis recta, Colchicum arenarium, Cyclamen purpurascens, Dianthus barbatus, Dictamnus albus, Doronicum hungaricum, Epipactis atrorubens, E. microphylla, E. tallosii, Equisetum hyemale, Hepatica nobilis, Hesperis sylvestris, Hordelymus europaeus, Iris aphylla subsp. hungarica, I. arenaria, I. sibirica, I. spuria, I. variegata, Jurinea mollis, Lilium martagon, Linaria biebersteinii, Linum flavum, Listera ovata, Lunaria rediviva, Lychnis coronaria, Melica altissima, Menyanthes trifoliata, Monotropa hypopithis, Muscari botryoides, Ophioglossum vulgatum, Orchis militaris, O. morio, O. purpurea, Ornithogalum brevistylum, Ornithogalum sphaerocarpum, Phlomis tuberosa, Primula veris, P. vulgaris, Pseudolysimachion incanum, Pulsatilla flavescens, Pyrola rotundifolia, Scilla vindobonensis, Scrophularia vernalis, Sedum urvillei subsp. hillebrandtii, Spiranthes spiralis, Stipa borysthenica, Stratiotes aloides, Thalictrum aquilegiifolium, Trollius europaeus, Veratrum album, Vinca herbacea, Vitis sylvestris, Wolffia arrhiza etc.
\end{abstract}

Keywords: coenology, flora mapping, Hungary, native flora

Összefoglalás - Jelen dolgozatunk a Magyarország edényes növényfajainak elterjedési atlasza térképeihez tartalmaz kiegészítő adatokat, elsősorban az Alföld és a Dunántúl területéről. A részletes adatokat elektronikus mellékletben közöljük. E florisztikai adatok a közép-európai flóratérképezés raszterhálózatának 149 kvadrátját érintik. 460 fajról közlünk összesen 1325 elterjedési adatot. Közülük kiemelkedő jelentőségű a Phegopteris connectilis megjelenése a Vértesalján, a Sternbergia colchiciflora és a Corydalis solida Duna-Tisza közi előfordulása, valamint az Euphorbia angulata és a Potentilla alba előkerülése a Nyírségben. Mindezeken kívül közleményünkben számos ritkább taxon új előfordulása található.

Kulcsszavak: cönológia, flóratérképezés, Magyarország, őshonos flóra 


\section{Bevezetés}

Dolgozatunkkal a néhány éve megjelent magyarországi flóraatlasz (BARTHA et al. 2015) térképeit szeretnénk helyesbíteni. A részletes adatokat a Kitaibelia elektonikus függelékében közöljük, amelyek elsősorban Kevey Balázs cönológiai adatbázisából származnak. Az utóbbi években számos cönológiai felvételt készítettünk az Alföld sziki és homoki tölgyeseiből: Jászság (Kevey és Urbán), Duna-Tisza köze (Kevey, Lendvai és Urbán), Hortobágy (Kevey és Molnár A.), Nyírség (Kevey, Demeter és Papp), Körös-vidék (Kevey és Papp). E felvételi anyagból választottuk ki azokat az előfordulási adatokat, amelyek a flóraatlasz megjelenésekor nem voltak regisztrálva az adott CEU kvadrában. Közlünk olyan adatokat is, amelyek előfordulását hosszú idő után sikerült megerősíteni. Elég nagy számmal vannak az adatsorban olyan korábban közölt adatok is, amelyek szintén hiányoznak a magyarországi flóraatlaszból. Ez arra utal, hogy az elterjedési térképek pontosításánál még sok florisztikai és cönológiai dolgozatot kell alaposan átnézni.

A fajok felsorolása három nagy rendszertani kategória (Pteridophyta, Dicotyledonopsida, Monocotyledonopsida) szerint, ezeken belül pedig ABC-sorrendben történik. A florisztikai adatokat a közép-európai flóratérképezés (NIKLFELD 1971) raszterkódjai alapján tüntetjük fel, megjelölve a településhatárt, a földrajzi nevet, a növénytársulás ÁNÉR kódját (BöLÖNI et al. 2011), a megtalálás évszámát. Korábban már publikált lelőhely esetében hivatkozunk a szóbanforgó cikkre. A fajok esetében KIRÁLY (2009) nómenklatúráját követjük.

\section{Eredmények}

A közölt florisztikai adatok elsősorban az Alföld és a Dunántúl területéről származnak, s a közép-európai flóratérképezés (NIKLFELD 1971) raszterhálózatának 149 kvadrátját érintik. 460 fajról közlünk összesen 1325 pontszerű előfordulási adatot. E növényfajok nagyobb része országosan gyakori, itt közölt adataikat flóratérképezési szempontból mégis fontosnak ítéljük, mert ezáltal is pontosabbá válik az ismert elterjedési területük.

A cönológiai felvételek ilyen jellegű átnézése arra hívta fel figyelmünket, hogy az Alföld florisztikai kutatottsága jelenleg még elég alacsony szinten áll. A Debrecen közelében levő halápi Álló-hegyen (8497.3) 9 cönológiai felvételt készítettünk, amelyben összesen 174 faj szerepel, s közülük 88 faj jelent a flóraatlaszhoz új előfordulást. Vagyis a felvételeinkben szereplő fajok csupán 50\%-a került elő innen a flóratérképezés során. Van azonban olyan kvadrát is, ahol még alacsonyabb számadatot kaptunk. A Vámospércs melletti Jónás-résznél (8497.4) egy felvételt készítettünk. A 103 fajból 66 faj jelent a kvadráthoz új előfordulást, azaz itt a felvételünkben szereplő fajok mindössze 44\%-át regisztrálták a flóratérképezés során. A flórakutatóknak így lesz még bőven dolguk ahhoz, hogy a flórakvadrátok fajkészletének dokumentáltsága egy elfogadható szintre emelkedjen.

Adataink között kiemelkedő jelentőségű a Phegopteris connectilis megjelenése a Vértesalján, a Sternbergia colchiciflora és a Corydalis solida Duna-Tisza közi előfordulása, valamint az Euphorbia angulata és a Potentilla alba előkerülése a Nyírségben. Mindezeken kívül közleményünkben számos ritkább taxon új előfordulása található: Allium paniculatum, A. sphaerocephalon, Asplenium adiantum-nigrum, Botrychium lunaria, Bulbocodium vernum, Clematis recta, Colchicum arenarium, Cyclamen purpurascens, Dianthus barbatus, Dictamnus albus, Doronicum hungaricum, Epipactis atrorubens, E. microphylla, E. tallosii, Equisetum hyemale, Hepatica nobilis, Hesperis sylvestris, Hordelymus europaeus, Iris aphylla subsp. hungarica, I. arenaria, I. sibirica, I. spuria, I. variegata, Jurinea mollis, Lilium martagon, Linaria biebersteinii, Linum flavum, Listera ovata, Lunaria rediviva, Lychnis coronaria, Melica 
altissima, Menyanthes trifoliata, Monotropa hypopithis, Muscari botryoides, Ophioglossum vulgatum, Orchis militaris, O. morio, O. purpurea, Ornithogalum brevistylum, Ornithogalum sphaerocarpum, Phlomis tuberosa, Primula veris, P. vulgaris, Pseudolysimachion incanum, Pulsatilla flavescens, Pyrola rotundifolia, Scilla vindobonensis, Scrophularia vernalis, Sedum urvillei subsp. hillebrandtii, Spiranthes spiralis, Stipa borysthenica, Stratiotes aloides, Thalictrum aquilegiifolium, Trollius europaeus, Veratrum album, Vinca herbacea, Vitis sylvestris, Wolffia arrhiza stb.

\section{Adatsor I.}

Alább csak a fontosabbnak ítélt, elsősorban védett fajok adatait soroljuk fel. Az adatok teljes listája az elektronikus mellékletben található.

\section{Pteridophyta}

\author{
Asplenium adiantum-nigrum $\mathrm{L}$. \\ Nyírség: \\ 8497.3: Debrecen-Haláp „Álló-hegy” M4 (Kevey \\ \& Papp ined.: 2019). \\ Equisetum hyemale $\mathrm{L}$. \\ Zselic: \\ 9673.3: Sántos „Herceg-forrás” J5 (Kevey ined.: \\ 2000).
}

\author{
Ophioglossum vulgatum L. \\ Dráva-sík: \\ 9973.2: Szentlőrinc „Aszai-árok: a horgásztó \\ közelében" D2 (Kevey ined.: 2001). \\ Phegopteris connectilis (Michx.) Watt \\ Vértes: \\ 8575.4: Oroszlány „Kis-Bükk” K1a (Kevey \& \\ Simon Gy. ined.: 2020). Egyetlen példány!
}

Dicotyledonopsida

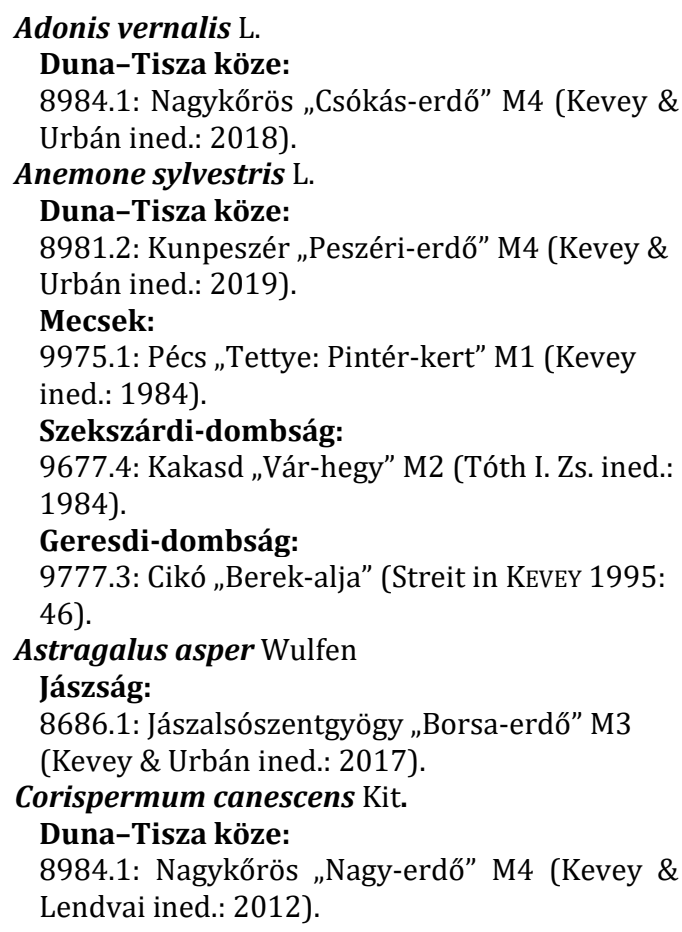

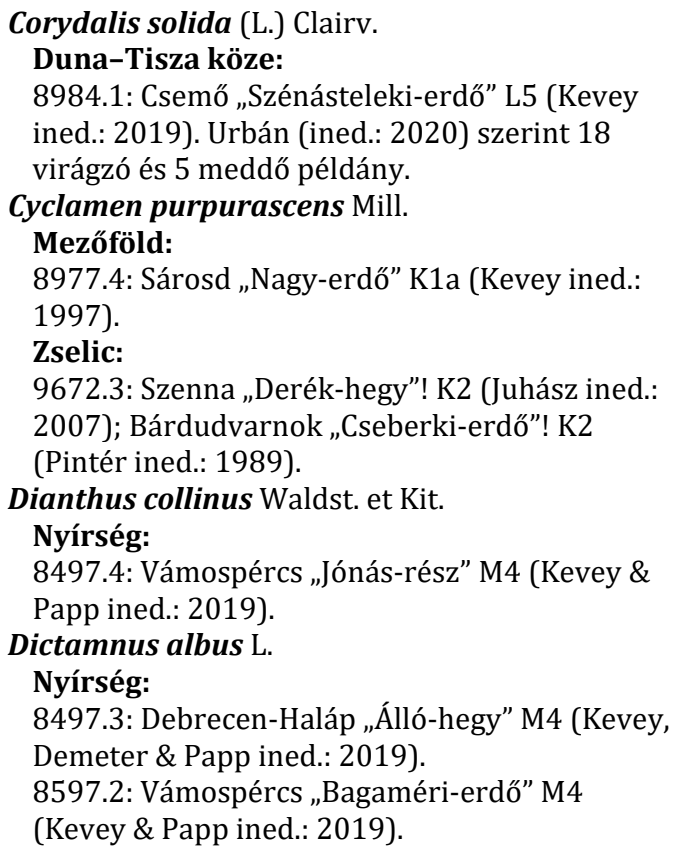




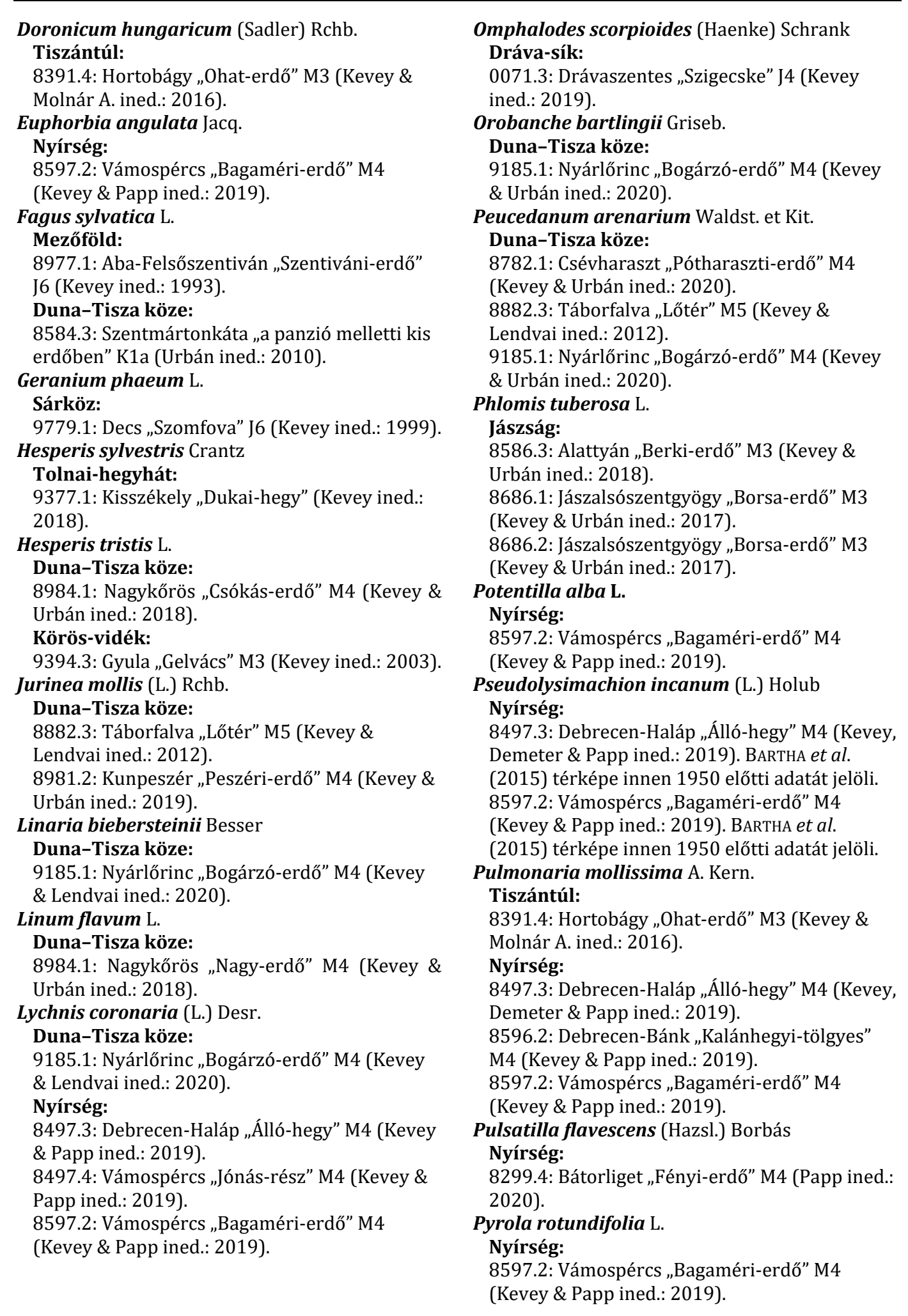



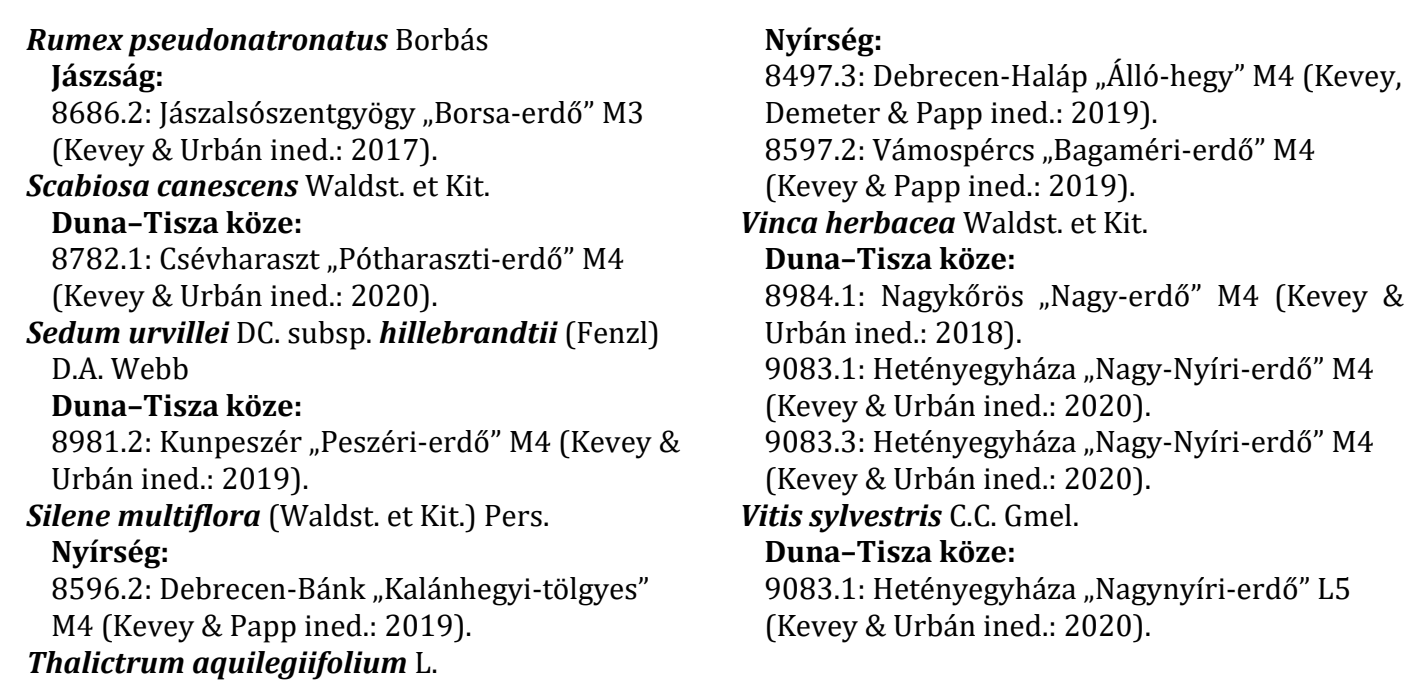

\section{Monocotyledonopsida}

\author{
Allium paniculatum $\mathrm{L}$. \\ Duna-Tisza köze: \\ 8984.1: Nagykőrös „Csókás-erdő” M4 (Kevey \& \\ Urbán ined.: 2019). \\ 9185.1: Nyárlőrinc „Bogárzó-erdő” M4 (Kevey \\ \& Urbán ined.: 2020). \\ Allium sphaerocephalon L. \\ Duna-Tisza köze: \\ 9083.3: Hetényegyháza „Nagy-Nyíri-erdő” M4 \\ (Kevey \& Urbán ined.: 2020). \\ Tiszántúl: \\ 8292.4: Újszentmargita „Tilos-erdő” M3 (Kevey \\ \& Molnár A. ined.: 2017). \\ 8391.4: Hortobágy „Ohat-erdő” M3 (Kevey \& \\ Molnár A. ined.: 2016). \\ Bulbocodium vernum $\mathrm{L}$. \\ Duna-Tisza köze: \\ 9884.1: Kelebia „Nagy-Kéri-erdő” M4 (Krnács \\ ined.: 2019). \\ Nyírség: \\ 8596.2: Debrecen-Bánk „Kalánhegyi-tölgyes” \\ olim M4 (Kevey \& Papp ined.: 2019). \\ Colchicum arenarium Waldst. et Kit. \\ Duna-Tisza köze: \\ 9083.1: Hetényegyháza „Nagy-Nyíri-erdő” M4 \\ (Kevey \& Urbán ined.: 2020). \\ 9083.3: Hetényegyháza „Nagy-Nyíri-erdő” M4 \\ (Kevey \& Urbán ined.: 2020). \\ Epipactis atrorubens Hoffm. ex Besser \\ Duna-Tisza köze: \\ 8882.3: Táborfalva „Lőtér” M5 (Kevey \& \\ Lendvai ined.: 2012). \\ Iris aphylla L. subsp. hungarica (Waldst. et Kit.) \\ Hegi
}

\author{
Nyírség: \\ 8299.4: Bátorliget „Fényi-erdő” M4 (Papp ined.: \\ 2020). BARTHA et al. (2015) térképe innen 1950 \\ előtti adatát jelöli. \\ 8497.4: Vámospércs „Jónás-rész” M4 (Papp \\ ined.: 2019). \\ 8597.2: Vámospércs „Bagaméri-erdő” M4 (Papp \\ ined.: 2019). \\ Iris arenaria Waldst. et Kit. \\ Duna-Tisza köze: \\ 8981.2: Kunpeszér „Peszéri-erdő” M4 (Kevey \& \\ Urbán ined.: 2019). \\ 9083.3: Hetényegyháza „Nagy-Nyíri-erdő” M4 \\ (Kevey \& Urbán ined.: 2020). \\ Nyírség: \\ 8497.3: Debrecen-Haláp „Álló-hegy” M4 (Kevey \\ \& Papp ined.: 2019). \\ 8596.2: Debrecen-Bánk „Kalánhegyi-tölgyes” \\ M4 (Kevey \& Papp ined.: 2019). \\ Iris spuria $\mathrm{L}$. \\ Körös-vidék: \\ 8796.3: Hencida „Csere-erdő” M3 (Kevey \& \\ Papp ined.: 2017). \\ Iris variegata $\mathrm{L}$. \\ Duna-Tisza köze: \\ 9082.1: Kunbaracs „Búhegyi-erdő” M4 (Kevey \\ \& Urbán ined.: 2020). \\ Muscari botryoides (L.) Mill. \\ Nyírség: \\ 8597.2: Vámospércs „Bagaméri-erdő” M4 \\ (Kevey \& Papp ined.: 2019). \\ Külső-Somogy: \\ 9372.4: Gamás „Vadéi-erdő” (Ötvös in KEVEY \\ 1995: 49).
}




\begin{tabular}{|c|c|}
\hline Zselic: & Dél-Zala: \\
\hline $\begin{array}{l}\text { 9672.4: Kaposvár „Som-hegy” (Horváth J. in } \\
\text { KEVEY 1995: 49). }\end{array}$ & $\begin{array}{l}\text { 9668.2: Iharosberény „Szentpáli-erdo” K2 } \\
\text { (Kevey ined.: 1987). }\end{array}$ \\
\hline Neottia nidus-avis (L.) Rich. & 9467.3: Eszteregnye-Obornak „Márki-erdő” K2 \\
\hline Nyírség: & (Kevey ined.: 1986). \\
\hline 8497.3: Debrecen-Haláp „Álló-hegy” M4 (Kevey, & Mecsek: \\
\hline Demeter \& Papp ined.: 2019). & 9876.1: Pécsvárad „Csiger-tető” LY4 (Kevey \\
\hline Orchis militaris L. & ined.: 2017). \\
\hline Dráva-sík: & Belső-Somogy: \\
\hline $\begin{array}{l}\text { 9973.2: Szentlőrinc „Aszai-árok: a horgásztó } \\
\text { mellett” D2 (Kevey ined.: 2000). }\end{array}$ & $\begin{array}{l}\text { 9570.2: Mesztegnyő „Dávodi-tó és Soponyai-tó } \\
\text { között” K1a (Kevey ined.: 2001). }\end{array}$ \\
\hline Orchis morio L. & 9769.3: Szenta „Döbrögi-erdő” K1a (Kevey \\
\hline Körös-vidék: & ined.: 2001). \\
\hline 8796.3: Hencida „Csere-erdő” M3 (Kevey \& & 9771.3: Mike „Patkány-domb” K1a (Kevey ined.: \\
\hline Papp ined.: 2017). BARTHA et al. (2015) térképe & 1989). \\
\hline innen 1950 előtti adatát jelöli. & Baranyai-dombság: \\
\hline Ornithogalum brevistylum Wolfner & 0075.2: Egerág „Halastói-erdő” K1a (Kevey \\
\hline Duna-Tisza köze: & ined.: 2012). \\
\hline 8984.1: Nagykőrös „Nagy-erdő” M4 (Kevey \& & 0075.3: Bosta „Nagy-erdő” K2 (Kevey ined.: \\
\hline Urbán ined.: 2018); Csemő „Szénásteleki-erdő” & 1994). \\
\hline M4 (Kevey \& L & Geresdi-dombság: \\
\hline Ornithogalum sphaerocarpum A. Kern. & 9777.3: Mecseknádasd „Borvicska-hegy” K2 \\
\hline Keszthelyi-hegység: & (Kevey ined. 2017). \\
\hline 9069.3: Zalaszántó „Kovácsi-hegy” LY4 (Kevey & Szekszárdi-dombság: \\
\hline ined.: 1985). & 9777.2: Szálka „Rác-erdő” K2 (Kevey ined.: \\
\hline 9069.4: Zalaszántó „Tátika” LY2, LY4 (Kevey & 1989). \\
\hline ined.: 1985). & Scilla vindobonensis Speta \\
\hline Bakony: & Sárköz: \\
\hline $\begin{array}{l}\text { 8872.2: Hárskút „Esztergály-völgy” LY2 (Kevey } \\
\text { ined.: 1999). }\end{array}$ & $\begin{array}{l}\text { 9879.1: Baja „Pandúr-sziget” J4, J6 (Kevey ined.: } \\
\text { 2019). }\end{array}$ \\
\hline 8373.4: Olaszfalu „Csengő-hegy” LY4 (Kevey & Jászság: \\
\hline ined.: 2017). & 8586.3: Alattyán „Berki-erdő” M3 (Kevey \& \\
\hline Bakonyalja: & Urbán ined.: 2018). \\
\hline $\begin{array}{l}\text { 8770.4: Kúp „Kúpi-erdő” K1a (Kevey ined.: } \\
\text { 1984). }\end{array}$ & $\begin{array}{l}\text { Sternbergia colchiciflora Waldst. et Kit. } \\
\text { Duna-Tisza köze: }\end{array}$ \\
\hline $\begin{array}{l}\text { 8871.1: Pápakovácsi „Attyai-erdő" K1a (Kevey } \\
\text { ined.: 2003). }\end{array}$ & $\begin{array}{l}\text { 9185.1: Nyárlőrinc „Bogárzó-erdő” M4 (Kevey } \\
\text { ined.: 2020). }\end{array}$ \\
\hline $\begin{array}{l}\text { 8871.3: Devecser „Beréndi-erdő” K1a (Kevey } \\
\text { ined. 1992).Devecser.Széki-erdő” K1a Kevev }\end{array}$ & Stipa borysthenica (Czern. ex Lindem.) Trautv. \\
\hline vecser „Szekı-erdo Kla (Kevey & 9083.3: Hetényegyháza „Nagy-Nyíri-erdő” M4 \\
\hline Észak-Zala: & (Kevey \& Urbán ined.: 2020). \\
\hline 9167.2: Gyűrűs „Kígyós” K2 (Kevey ined.: & 9185.1: Nyárlőrinc „Bogárzó-erdő” M4 (Kevey \\
\hline 1993). & \& Urbán ined.: 2020). \\
\hline 9168.2: Vindornyaszőlős „Alsó-erdő” K1a & Veratrum album $\mathrm{L}$. \\
\hline (Kevey ined.: 1993). & Dráva-sík: \\
\hline $\begin{array}{l}\text { 9267.4: Pölöske „Sohollár” K1a (Kevey ined.: } \\
\text { 2014). }\end{array}$ & $\begin{array}{l}\text { 9972.1: Merenye „Meggyes-erdő” J5 (Kevey } \\
\text { ined.: 1999). }\end{array}$ \\
\hline
\end{tabular}

\section{Köszönetnyilvánítás}

Köszönetünk illeti azon kollégákat, akik közöletlen adataikat rendelkezésünkre bocsátották, vagy segítségünkre voltak egyes nehezen határozható fajok azonosításával: Csiky János, Horvát Adolf Olivér†, Juhász Magdolna, Krnács György, Molnár Zsolt, Pál Róbert, Simon György, Tóth Imre†, Tóth István Zsolt. 


\section{Rövidítések}

!: az adatközlő által jelzett lelőhelyen a szóban forgó növényt megtaláltuk ex verb.: ex verbis (szóbeli közlés) ined.: ineditum (kiadatlan közlés)

Élőhelytípusok:

D2: kiszáradó láprét (Succiso-Molinietum hungaricae)

H5a: löszlegelő (Cynodonti-Poëtum angustifoliae)

J2: kiszáradó kőrisláp (Veratro albi-Fraxinetum angustifoliae)

J3: mandulalevelű bokorfüzes (Polygono hydropiperiSalicetum triandrae)

J4: fekete- és fehérnyár ligeterdő (Carduo crispi populetum nigrae, Senecioni sarraceniciPopuletum albae)

J5: $\quad$ égerliget (Aegopodio-Alnetum glutinosae, Carici pendulae-Alnetum glutinosae, Paridi quadrifoliaeAlnetum glutinosae)

J6: tölgy-kőris-szil liget (Fraxino pannonicaeUlmetum, Pimpinello majoris-Ulmetum, Scillo vindobonensi-Ulmetum)

K1a: gyertyános-kocsányos tölgyes (Carpesio abrotanoidis-Carpinetum, Circaeo-Carpinetum, Convallario-Carpinetum, Corydali cavaeCarpinetum, Fraxino pannonicae-Carpinetum, Scillo vindobonensi-Carpinetum, Veronico montanae-Carpinetum)

K2: gyertyános-kocsánytalan tölgyes (Asperulo taurinae-Carpinetum, Corydali pumilaeCarpinetum, Helleboro dumetorum-Carpinetum )
K5: bükkös (Daphno laureolae-Fagetum, Doronico austriaci-Fagetum, Helleboro odori-Fagetum, Leucojo verno-Fagetum, Vicio oroboidi-Fagetum)

L2a: cseres-kocsánytalan tölgyes (Potentillo micranthae-Quercetum dalechampii)

L5: gyöngyvirágos-tölgyes (Convallari-Quercetum roboris, Polygonato latifolio-Quercetum roboris)

LY1: szurdokerdő (Scutellerio altissimae-Aceretum pseudoplatani)

LY2: törmeléklejtő-erdő (Mercuriali-Tilietum)

LY4: tetőerdő (Aconito anthorae-Fraxinetum orni, Veratro nigri-Fraxinetum orni)

M1: karsztbokorerdő (Inulo spiraeifoliae-Quercetum pubescentis)

M2: nyílt lösztölgyes (Aceri tatarici-Quercetum pubescentis-roboris)

M3: nyílt sziki tölgyes (Galatello-Quercetum roboris)

M4: nyílt homoki tölgyes (Iridi variegatae-Quercetum roboris, Melampyro debreceniensi-Quercetum roboris)

M5: nyáras-borókás (Junipero-Populetum albae)

\section{Irodalom}

Bartha D., Király G., Schmidt D., Tiborcz V., Barina Z., Csiky J., Jakab G., Lesku B., Schmotzer A., Vidéki R., Vojткó A. \& Zólyomi Sz. (szerk.) (2015): Magyarország edényes növényfajainak elterjedési atlasza. Nyugat-magyarországi Egyetem Kiadó, Sopron, 330 pp.

Boros Á. (1870): Florisztikai közlemények V. - Botanikai Közlemények 57(1): 69-72.

BöLÖNI J., MolnÁr Zs. \& KUn A. 2011: Magyarország élőhelyei. Vegetációtípusok leírása és határozója. ÁNÉR 2011. - MTA Ökológiai és Botanikai Kutatóintézete, Vácrátót, 441 pp.

HANGAY O. (1889): Erőszakolt flóravidék. - Orvos-Természettudományi Értesítő II. Természettudományi szak 14: 153-162.

HoRvÁt A. O. (1977): Pótlások és kiegészítések „A Mecsek-hegység és déli síkjának növényzete” ismeretéhez 1942-1971 II. - Janus Pannonius Múzeum Évkönyve 19 (1974): 37-55.

KEveY B. (1981): Adatok Magyarország flórájának és vegetációjának ismeretéhez I. - Botanikai Közlemények 67(3): 179-182.

KEVEY B. (1983): Adatok Magyarország flórájának és vegetációjának ismeretéhez II. - Botanikai Közlemények 70(1-2): 19-23.

Kevey B. (1984): Dég parkerdeinek tölgy-kőris-szil ligetei. - Botanikai Közlemények 71(1-2): 51-61.

KEVEY B. (1985): Adatok Magyarország flórájának és vegetációjának ismeretéhez III. - Botanikai Közlemények 72(1-2): 155-158.

KEVEY B. (1987): A martonvásári Kastélypark tölgy-kőris-szil ligeterdői. - Botanikai Közlemények 73(12) (1986): 33-42.

KEvEY B. (1988): Adatok Magyarország flórájának és vegetációjának ismeretéhez IV. - Botanikai Közlemények 74-75(1-2) (1987-1988): 93-100. 
KEVEY B. (1990): Adatok Magyarország flórájának és vegetációjának ismeretéhez V. - Botanikai Közlemények 76(1-2, 1989): 83-96.

KEVEY B. (1993): Adatok Magyarország flórájának és vegetációjának ismeretéhez VI. - Botanikai Közlemények 80(1): 53-60.

KEVEY B. (1995): Adatok Magyarország flórájának és vegetációjának ismeretéhez VII. - Botanikai Közlemények 82(1-2): 45-53.

KEVEY B. (2008a): A Zákányi-dombok bükkösei (Doronico austriaci-Fagetum BoRHIDI et KEVEY 1996). Somogyi Múzeumok Közleményei 18: 17-30.

KEVEY B. (2008b): Szurdokerdő-fragmentumok a Zákányi-dombokon (Polysticho setiferi-Aceretum pseudoplatani KeVEY in BoRHIDI et KEVEY 1996). - Natura Somogyiensis 12: 31-46.

KEVEY B. (2013): Belső-Somogy homoki gyertyános-tölgyesei. - (Fraxino pannonicae-Carpinetum Soó et BoRHIDI in Soó 1962). - Kaposvári Rippl-Rónai Múzeum Közleményei 1: 17-40.

KEVEY B. (2015a): Adatok Magyarország flórájának és vegetációjának ismeretéhez X. - Botanikai Közlemények 102(1-2): 39-60.

Kevey B. (2015b): A Tengelici-homokvidék zárt homoki tölgyesei (Polygonato latifolii-Querectum roboris) Borhidi in Borhidi et Kevey 1996). - Natura Somogyiensis 27: 5-36.

KEVEY B. (2016): A Villányi-hegység gyertyános-tölgyesei [Asperulo taurinae-Carpinetum (A. O. HoRváT 1946) Soó et BoRHIDI in Soó 1962]. - e-Acta Naturalia Pannonica 10: 21-46.

KeVEY B. (2018): Korrekció „KeVEY B.: A Zákányi-dombok bükkösei (Doronico austriaci-Fagetum Borhidi et Kevey 1996)" című tanulmányhoz [Somogyi Múzeumok Közleményei 18 (2008): 17-30]. Kaposvári Rippl-Rónai Múzeum Közleményei 05: 57-58.

Kevey B. (2020): A Csepel-sziget fehérnyár-ligetei (Senecioni sarracenici-Populetum albae Kevey in Borhidi \& Kevey 1996). - Kitaibelia 25(1): 57-78.

KEVEY B., BoRHidi A. \& KLUJBER K. (1998): Belső-Somogy homoki bükkösei (Leucojo verno-Fagetum KeVEY et BoRHIDi 1992). - Somogyi Múzeumok Közleményei 13: 241-256.

Kevey B., Orosz-Kovács Zs., Tóth I. \& Borhidi A. (1992): Adatok a Béda-Karapancsa Tájvédelmi Körzet flórájához. - Dunántúli Dolgozatok (A) Természettudományi Sorozat 6: 13-25.

Kevey B. \& Lendvai G. (2015): A Tengelici-homokvidék gyertyános-tölgyesei (Convallario-Carpinetum KeVEY 2008). - Natura Somogyiensis 26: 5-37.

Kevey B., Lendvai G. \& Simon Gy. (2014): A Velencei-hegység gyertyános-tölgyesei (Corydali cavaeCarpinetum Kevey 2008). - Kanitzia 21: 219-244.

Kevey B., MAJLÁth I. \& MolnÁR M. (2016): Changes in the hardwood groves of the Martonvásár manor park (Hungary) in the last 30 years. - Acta Botanica Hungarica 58(3-4): 265-286. + Table S1-S3.

KEvEY B. \& TóTH I. (1992): A béda-karapancsai Duna-ártér gyertyános-tölgyesei (Querco roboriCarpinetum). - Dunántúli Dolgozatok (A) Természettudományi Sorozat 6: 27-40.

Kevey B. \& Tóth I. (2018): A Mohácsi-sziget tölgy-kőris-szil ligetei (Scillo vindobonensis-Ulmetum Kevey in Borhidi et Kevey 1996). - Botanikai Közlemények 105(1): 109-128.

KEvEY B. \& TóTH I. (2000): Adatok a hazai Alsó-Duna-ártér flórájához. - Kitaibelia 5(1): 131-143.

KIRÁLY G. (szerk.) (2009): Új magyar füvészkönyv. Magyarország hajtásos növényei. Határozókulcsok. Aggteleki Nemzeti Park Igazgatóság, Jósvafő, 616 pp.

LENDVAI G., HoRvÁth A. \& Kevey B. (2014): Tatárjuharos tölgyesek (Aceri tatarici-Quercetum pubescentisroboris Zólyomi 1957) a Mezőföldön. - Botanikai Közlemények 101(1-2): 145-187.

MAJER A. (1979): Búcsú egy különleges erdőtől. - Erdőgazdaság és Faipar 1979(3): 10-12.

MAjER A. (1984): Dég és környékének természetes növénytakarója. - In: FÁKLYA Cs. \& VereBiCs G. (szerk.), Dég. Honismereti és természetrajzi tanulmányok. Községi Tanács, Dég, pp. 63-77.

STETÁK D. (2000): Adatok a Duna-Dráva Nemzeti Park Gemenci Tájegysége flórájához. - Kitaibelia 5(1): $145-176$.

TóTH I. (1958): Az Alsó-Dunaártér erdőgazdálkodása a termőhely- és az erdőtípusok összefüggése. Erdészeti Kutatások 1958(1-2): 77-160.

Elektronikus melléklet / Electronic appendix:

Adatsor II. (teljes adatsor) / Dataset II. (the full dataset)

Beérkezett / received: 2020. 11. 24. • Elfogadva / accepted: 2021. 02. 16. 
Kevey B., Demeter L., Lendvai G., Molnár A., PAPP L. \& URbán S. (2021):

Pótlások Magyarország edényes növényfajainak elterjedési atlaszához XII. /

Contributions to the Atlas Florae Hungariae XII.

Kitaibelia 26(1): 77-84.

DOI: 10.17542/kit.26.77

\section{Elektronikus melléklet / Electronic appendix}

Adatsor II.

(teljes adatsor)

Pteridophyta

Asplenium adiantum-nigrum L.

Nyírség:

8497.3: Debrecen-Haláp „Álló-hegy” M4 (Kevey \& Papp ined.: 2019).

\section{Asplenium trichomanes L.}

Dél-Zala:

9667.4: Surd „Bükkfakúti-erdő” K2 (Kevey ined.: 1987).

Belső-Somogy:

9869.3: Bélavár „Kerék-hegy” K1a, K5 (KeVEY in KEVEY et al. 1998: 247, „a Palinai-erdő felé vezető út mellett" K1a KEVEY in KeVEY et al. 1998: 247).

Athyrium filix-femina (L.) Roth

Mezőföld:

9378.1: Bikács-Kistápé „Akalacsi-erdő” K1a (KEVEY 1985: 155).

Botrychium Iunaria (L.) Sw.

Duna-Tisza köze:

8882.3: Táborfalva „Lőtér” M5 (Kevey \& Lendvai ined.: 2012).

Dryopteris carthusiana (Vill.) H.P. Fuchs

Nyírség:

8497.3: Debrecen-Haláp „Álló-hegy” L5 (Kevey \& Papp ined.: 2019).

Mezőföld:

9176.2: Dég „Kastély-park: a Kislángi-árok mentén egy kis folt” J6 (KEVEY 1983: 20).

Tolnai-hegyhát:

9377.1: Kisszékely „Kisszékelyi-erdő K1a (Tóth I. Zs. in Kevey 1995: 46).

Equisetum fluviatile L. em. Ehrh.

Nyírség:

8299.4: Bátorliget „Fényi-erdő" M4 (Kevey \& Papp ined.: 2020).

\section{Equisetum hyemale L.}

Zselic:

9673.3: Sántos „Herceg-forrás” J5 (Kevey ined.: 2000).

Equisetum palustre L.

Duna-Tisza köze:

8981.2: Kunpeszér „Peszéri-erdő” M4 (Kevey \& Urbán ined.: 2019).

Equisetum telmateia Ehrh.

Mezőföld:

9177.3: Pusztaegres „Örspuszta” (Kevey 1988: 93), „a halastó melletti erdőben” J6 (Kevey ined.: 1985). 
Ophioglossum vulgatum $\mathrm{L}$.

Mezőföld:

9278.3: Németkér „Hardi-ér” (Kevey \& Lendvai in Kevey 1990: 85).

\section{Csepel-sziget:}

8779.4: Szigetújfalu „Újfalusi-erdo” J6 (Boros 1970: 71).

Sárköz:

9678.2: Bogyiszló „a Sió-töltés külső oldalán levő erdőben” (Zörényi in KEVEY 1993: 54).

9779.1: Decs „Szomfova” K1a (Kevey \& Tóth I. ined.: 1989), „Gyöngyös-oldal” K1a (TóTH I. 1958: 129).

9878.2: Báta „Gyűrűsalj” J6 (Kevey \& Tóth I. ined.: 1997).

9879.1: Baja „Cserta” (TóTH I. 1958: 129), „Közép-Pörböly” (TóTH I. 1958: 129).

Dráva-sík:

9973.2: Szentlőrinc „Aszai-árok: a horgásztó közelében” D2 (Kevey ined.: 2001).

\section{Phegopteris connectilis (Michx.) Watt}

Vértes:

8575.4: Oroszlány „Kis-Bükk” K1a (Kevey \& Simon Gy. ined. 2020). Egyetlen példány!

\section{Dicotyledonopsida}

Achillea ochroleuca Ehrh.

Duna-Tisza köze:

9083.3: Hetényegyháza „Nagy-Nyíri-erdő” M4 (Kevey \& Urbán ined.: 2020).

\section{Achillea pannonica Scheele}

Jászság:

8586.3: Alattyán „Berki-erdo”” M3 (Kevey \& Urbán ined.: 2018).

Duna-Tisza köze:

9082.1: Kunbaracs „Búhegyi-erdő” M4 (Kevey \& Urbán ined.: 2020).

\section{Körös-vidék:}

8796.3: Hencida „Csere-erdő” M3 (Kevey \& Papp ined.: 2017).

9293.4: Doboz „Papholt-erdő” M3 (Kevey ined.: 2002).

9394.3: Gyula „Kutyahelyi-erdő” M3 (Kevey ined.: 2003).

Nyírség:

8299.4: Bátorliget „Fényi-erdő” M4 (Kevey \& Papp ined.: 2020).

8497.3: Debrecen-Haláp „Álló-hegy” M4 (Kevey, Demeter \& Papp ined.: 2019).

8497.4: Vámospércs „Jónás-rész” M4 (Kevey \& Papp ined.: 2019).

8596.2: Debrecen-Bánk „Kalánhegyi-tölgyes” M4 (Kevey \& Papp ined.: 2019).

8597.2: Vámospércs „Bagaméri-erdő” M4 (Kevey \& Papp ined.: 2019).

Acinos arvensis (Lam.) Dandy

Duna-Tisza köze:

9884.1: Kelebia „Nagy-Kéri-erdo”” M4 (Kevey \& Lendvai ined.: 2019).

\section{Actaea spicata L.}

Belső-Somogy:

9570.2: Mesztegnyő „Mélyéger” K1a (Kevey 2013: 31).

9869.3: Bélavár „Kerék-hegy” K5 (Kevey 2013: 31).

Villányi-hegység:

0175.2: Bisse „Pécsi-lapis” K5 (Kevey 1988: 96), „Remete” LY1 (KeVEY 1988: 96); Kistótfalu „Átai-hegy” LY1 (KEVEY 1988: 96).

\section{Adonis vernalis $\mathrm{L}$.}

Duna-Tisza köze:

8984.1: Nagykőrös „Csókás-erdő” M4 (Kevey \& Urbán ined.: 2018).

Sárköz:

9778.3: Alsónyék (Karácsony in Kevey 1995: 46). 
Adoxa moschatellina L.

Mezőföld:

8678.4: Martonvásár „Kastély-park” J6 (Boros in KEVEY 1987: 36; Kevey ined.: 2011).

9176.2: Dég „Kastély-park” J6 (KeVEY 1981: 180).

\section{Aegopodium podagraria L.}

\section{Sárköz:}

9678.2: Szekszárd „Borrév” J6 (Kevey ined.: 2019).

9779.1: Érsekcsanád „Veránka” J6 (TóTH I. 1958: 125).

9779.3: Baja „Koppány” J6 (Kárpáti in KevEy \& TóTH 2000: 135).

Mezőföld:

8976.4: Soponya-Nagyláng „Fácános-erdő” J6 (Horvát \& Kevey in KEVEY 1981: 180), „Kastély-park” J6, K1a (Kevey ined.: 1981).

Csepel-sziget:

8779.3: Ráckeve „Silling-erdő” J6 (Kevey ined.: 1978).

8879.1: Ráckeve „Besnyő” J6 (Kevey ined.: 1988).

8979.1: Makád „Rókás” J6 (Kevey ined.: 1989).

\section{Ajuga genevensis L.}

Jászság:

8686.2: Jászalsószentgyögy „Borsa-erdő” M3 (Kevey \& Urbán ined.: 2017).

Duna-Tisza köze:

8981.2: Kunpeszér „Peszéri-erdő” M4 (Kevey \& Urbán ined.: 2019).

9082.1: Kunbaracs „Búhegyi-erdő” M4 (Kevey \& Urbán ined.: 2020).

9083.3: Hetényegyháza „Nagy-Nyíri-erdő” M4 (Kevey \& Urbán ined.: 2020).

Tiszántúl:

8292.4: Újszentmargita „Tilos-erdő” M3 (Kevey \& Molnár A. ined.: 2017).

Körös-vidék:

8796.3: Hencida „Csere-erdő” M3 (Kevey \& Papp ined.: 2017).

9293.4: Doboz „Papholt-erdő” M3 (Kevey ined.: 2002).

Nyírség:

8497.3: Debrecen-Haláp „Álló-hegy” M4 (Kevey, Demeter \& Papp ined.: 2019).

8497.4: Vámospércs „Jónás-rész” M4 (Kevey \& Papp ined.: 2019).

8597.2: Vámospércs „Bagaméri-erdő” M4 (Kevey \& Papp ined.: 2019).

\section{Ajuga reptans L.}

Körös-vidék:

9394.3: Gyula „Gelvács” M3 (Kevey ined.: 2003).

Alkanna tinctoria (L.) Tausch

Duna-Tisza köze:

9083.3: Hetényegyháza „Nagy-Nyíri-erdő” M4 (Kevey ined.: 2020).

Alliaria petiolata (M. Bieb.) Cavara et Grande

Nyírség:

8597.2: Vámospércs „Bagaméri-erdő” M4 (Kevey \& Papp ined.: 2019).

Körös-vidék:

9293.4: Doboz „Papholt-erdő” M3 (Kevey ined.: 2002).

Alnus incana (L.) Moench

Mecsek:

9874.3: Hetvehely „Sás-völgy” J5 (Kevey ined.: 2000).

\section{Alyssum desertorum Stapf}

Duna-Tisza köze:

8882.3: Táborfalva „Lőtér” M5 (Kevey \& Lendvai ined.: 2012).

8981.2: Kunpeszér „Peszéri-erdő” M4 (Kevey \& Urbán ined.: 2019). 
Alyssum montanum L.

Duna-Tisza köze:

9083.3: Hetényegyháza „Nagy-Nyíri-erdő" M4 (Kevey \& Urbán ined.: 2020).

Nyírség:

8497.3: Debrecen-Haláp „Álló-hegy” M4 (Kevey \& Papp ined.: 2019).

Alyssum tortuosum Willd.

Duna-Tisza köze:

8984.1: Nagykőrös „Csókás-erdő” M4 (Kevey \& Urbán ined.: 2018).

\section{Anemone sylvestris L.}

Velencei-hegység:

8777.2: Lovasberény „Hársas-teto” M2 (Kevey \& Lendvai ined.: 2005; Kevey \& Lendvai in LENDVAI et al. 2014: 208).

Duna-Tisza köze:

8981.2: Kunpeszér „Peszéri-erdő” M4 (Kevey \& Urbán ined.: 2019).

Mecsek:

9975.1: Pécs „Tettye: Pintér-kert” M1 (Kevey ined.: 1984).

Szekszárdi-dombság:

9677.4: Kakasd „Vár-hegy” M2 (Tóth I. Zs. ined.: 1984).

Geresdi-dombság:

9777.3: Cikó „Berek-alja” (Streit in KEvEY 1995: 46).

Anthemis ruthenica L.

Duna-Tisza köze:

9083.1: Hetényegyháza „Nagy-Nyíri-erdő” M4 (Kevey \& Urbán ined.: 2020).

Anthriscus sylvestris (L.) Hoffm.

Jászság:

8586.3: Alattyán „Berki-erdő” M3 (Kevey \& Urbán ined.: 2018).

Arabidopsis thailana (L.) Heynh.

Duna-Tisza köze:

9884.1: Kelebia „Nagy-Kéri-erdő” M4 (Kevey \& Lendvai ined.: 2019).

Tiszántúl:

8292.4: Újszentmargita „Tilos-erdő” M3 (Kevey \& Molnár A. ined.: 2017).

Nyírség:

8497.3: Debrecen-Haláp „Álló-hegy” M4 (Kevey \& Papp ined.: 2019).

8497.4: Vámospércs „Jónás-rész” M4 (Kevey \& Papp ined.: 2019).

Körös-vidék:

9394.3: Gyula „Kutyahelyi-erdő” M3 (Kevey ined.: 2003).

Arabis glabra (L.) Bernh.

Duna-Tisza köze:

9082.1: Kunbaracs „Búhegyi-erdő” M4 (Kevey \& Urbán ined.: 2020).

Nyírség:

8497.3: Debrecen-Haláp „Álló-hegy” M4 (Kevey, Demeter \& Papp ined.: 2019).

8497.4: Vámospércs „Jónás-rész” M4 (Kevey \& Papp ined.: 2019).

Arabis hirsuta (L.) Scop.

Duna-Tisza köze:

8981.2: Kunpeszér „Peszéri-erdő” M4 (Kevey \& Urbán ined.: 2019).

9185.1: Nyárlőrinc „Bogárzó-erdő” M4 (Kevey \& Urbán ined.: 2020).

Nyírség:

8497.4: Vámospércs „Jónás-rész” M4 (Kevey \& Papp ined.: 2019). 
Arctium minus (Hill) Bernh.

Nyírség:

8299.4: Bátorliget „Fényi-erdő” L5 (Kevey \& Papp ined.: 2020).

8596.2: Debrecen-Bánk „Kalánhegyi-tölgyes” L5 (Kevey \& Papp ined.: 2019).

Körös-vidék:

9394.3: Gyula „Kutyahelyi-erdő” M3 (Kevey ined.: 2003).

Arenaria serpyllifolia L.

Duna-Tisza köze:

8984.1: Nagykőrös „Csókás-erdő” M4 (Kevey \& Lendvai ined.: 2012).

Artemisia absinthium L.

Nyírség:

8497.3: Debrecen-Haláp „Álló-hegy” M4 (Kevey \& Papp ined.: 2019).

\section{Artemisia pontica L.}

Jászság:

8586.3: Alattyán „Berki-erdő” M3 (Kevey \& Urbán ined.: 2018).

Duna-Tisza köze:

9082.1: Kunbaracs „Búhegyi-erdő” M4 (Kevey \& Urbán ined.: 2020).

9185.1: Nyárlőrinc „Bogárzó-erdő” M4 (Kevey \& Urbán ined.: 2020).

Tiszántúl:

8391.4: Hortobágy „Ohat-erdo”" M3 (Kevey \& Molnár A. ined.: 2016).

Körös-vidék:

8796.3: Hencida „Csere-erdő” M3 (Kevey \& Papp ined.: 2017).

9394.3: Gyula „Kutyahelyi-erdő” M3 (Kevey ined.: 2003).

\section{Asperugo procumbens $\mathrm{L}$.}

Körös-vidék:

9193.1: Bélmegyer „Szolga-erdő” M3 (Kevey ined.: 2002).

\section{Asperula cynanchica L.}

Duna-Tisza köze:

8984.1: Nagykőrös „Csókás-erdő” M4 (Kevey \& Urbán ined.: 2018).

9083.3: Hetényegyháza „Nagy-Nyíri-erdő” M4 (Kevey \& Urbán ined.: 2020).

Nyírség:

8497.3: Debrecen-Haláp „Álló-hegy” M4 (Kevey \& Papp ined.: 2019).

8497.4: Vámospércs „Jónás-rész” M4 (Kevey \& Papp ined.: 2019).

\section{Aster sedifolius $\mathrm{L}$.}

Körös-vidék:

8796.3: Hencida „Csere-erdő” M3 (Kevey \& Papp ined.: 2017).

Aster linosyris (L.) Bernh.

Duna-Tisza köze:

9083.3: Hetényegyháza „Nagy-Nyíri-erdő” M4 (Kevey \& Urbán ined.: 2020).

Tiszántúl:

8391.4: Hortobágy „Ohat-erdo” M3 (Kevey \& Molnár A. ined.: 2016).

Körös-vidék:

8796.3: Hencida „Csere-erdő” M3 (Kevey \& Papp ined.: 2017).

9193.1: Bélmegyer „Szolga-erdo”” M3 (Kevey ined.: 2002).

\section{Astragalus asper Wulfen}

Jászság:

8686.1: Jászalsószentgyögy „Borsa-erdő” M3 (Kevey \& Urbán ined.: 2017). 
Astragalus cicer $\mathrm{L}$.

Duna-Tisza köze:

8882.3: Táborfalva „Lőtér” M5 (Kevey \& Lendvai ined.: 2012).

9082.1: Kunbaracs „Búhegyi-erdő” M4 (Kevey \& Urbán ined.: 2020).

\section{Astragalus glycyphyllos L.}

Jászság:

8586.3: Alattyán „Berki-erdô” M3 (Kevey \& Urbán ined.: 2018).

Duna-Tisza köze:

9082.1: Kunbaracs „Búhegyi-erdő” M4 (Kevey \& Urbán ined.: 2020).

9083.3: Hetényegyháza „Nagy-Nyíri-erdő” M4 (Kevey \& Urbán ined.: 2020).

Körös-vidék:

8796.3: Hencida „Csere-erdő” M3 (Kevey \& Papp ined.: 2017).

9293.4: Doboz „Papholt-erdő” M3 (Kevey ined.: 2002).

Nyírség:

8597.2: Vámospércs „Bagaméri-erdő” M4 (Kevey \& Papp ined.: 2019).

\section{Astragalus onobrychis L.}

Duna-Tisza köze:

8981.2: Kunpeszér „Peszéri-erdő” M4 (Kevey \& Urbán ined.: 2019).

9185.1: Nyárlőrinc „Bogárzó-erdő” M4 (Kevey \& Urbán ined.: 2020).

\section{Atropa belladonna L.}

Mezőföld:

8678.4: Martonvásár „Kastély-park” J6 (KevEY 1983: 21).

Berteroa incana (L.) DC.

Duna-Tisza köze:

8984.1: Nagykőrös „Nagy-erdő” M4 (Kevey \& Urbán ined.: 2018).

\section{Betonica officinalis $\mathrm{L}$.}

Duna-Tisza köze:

8981.2: Kunpeszér „Peszéri-erdő” M4 (Kevey \& Urbán ined.: 2019).

9082.1: Kunbaracs „Búhegyi-erdő” M4 (Kevey \& Urbán ined.: 2020).

Körös-vidék:

8796.3: Hencida „Csere-erdő” M3 (Kevey \& Papp ined.: 2017).

Nyírség:

8497.3: Debrecen-Haláp „Álló-hegy” M4 (Kevey, Demeter \& Papp ined.: 2019).

8497.4: Vámospércs „Jónás-rész” M4 (Kevey \& Papp ined.: 2019).

8596.2: Debrecen-Bánk „Kalánhegyi-tölgyes” M4 (Kevey \& Papp ined.: 2019).

Buglossoides arvensis (L.) I.M. Johnston

Duna-Tisza köze:

9083.1: Hetényegyháza „Nagy-Nyíri-erdő” M4 (Kevey \& Urbán ined.: 2020).

Nyírség:

8597.2: Vámospércs „Bagaméri-erdő” M4 (Kevey \& Papp ined.: 2019).

Buglossoides purpurocaerulea (L.) I.M. Johnston

Duna-Tisza köze:

9082.1: Kunbaracs „Búhegyi-erdő” M4 (Kevey \& Urbán ined.: 2020).

\section{Bunias orientalis L.}

Duna-Tisza köze:

8981.2: Kunpeszér „Peszéri-erdő” M4 (Kevey \& Urbán ined.: 2019).

Camelina microcarpa Andrz. ex DC.

Duna-Tisza köze:

8984.1: Nagykőrös „Nagy-erdő” M4 (Kevey \& Lendvai ined.: 2012).

9884.1: Kelebia „Nagy-Kéri-erdő” M4 (Kevey \& Lendvai ined.: 2019). 
Campanula glomerata L. Duna-Tisza köze:

8981.2: Kunpeszér „Peszéri-erdő” M4 (Kevey \& Urbán ined.: 2019). 9082.1: Kunbaracs „Búhegyi-erdő” M4 (Kevey \& Urbán ined.: 2020). 9185.1: Nyárlőrinc „Bogárzó-erdő” M4 (Kevey \& Urbán ined.: 2020).

\section{Campanula latifolia L.} Mezőföld:

8678.4: Martonvásár „Kastély-park” J6 (KEVEY 1987: 36). Ültetve és elvadulva!

\section{Campanula persicifolia $\mathrm{L}$.} Nyírség:

8597.2: Vámospércs „Bagaméri-erdő” M4 (Kevey \& Papp ined.: 2019).

\section{Campanula rapunculus L.}

Duna-Tisza köze:

8984.1: Nagykőrös „Csókás-erdő” M4 (Kevey \& Lendvai ined.: 2012).

Nyírség:

8597.2: Vámospércs „Bagaméri-erdő” M4 (Kevey \& Papp ined.: 2019).

\section{Campanula rotundifolia $\mathrm{L}$.}

Nyírség:

8497.4: Vámospércs „Jónás-rész” M4 (Kevey \& Papp ined.: 2019).

8596.2: Debrecen-Bánk „Kalánhegyi-tölgyes” M4 (Kevey \& Papp ined.: 2019).

8597.2: Vámospércs „Bagaméri-erdő” M4 (Kevey \& Papp ined.: 2019).

Cardamine bulbifera (L.) Crantz

Nyírség:

8597.2: Vámospércs „Bagaméri-erdo”” L5 (Kevey \& Papp ined.: 2019).

\section{Mezőföld:}

9378.1: Vajta „Nagy-erdő” K1a (Horvát \& Kevey in KEVEY 1981: 180).

9278.4: Németkér „Barát-erdő” K1a (KEVEY 1981: 180).

\section{Cardamine impatiens L.}

Komáromi-síkság:

8373.1: Bőny „Szőlő-hegy” K1a (Kevey ined.: 2005).

Csepel-sziget:

8779.3: Szigetújfalu „Újfalusi-erdő” J6 (Kevey ined.: 1978).

8879.3: Lórév „Makádi-erdő” J6 (Kevey ined.: 1977).

8979.1: Makád „Rókás” J6 (Kevey ined.: 1989).

Sárköz:

9779.1: Decs „Szomfova” K1a, J6 (Kevey ined.: 1999).

9779.3: Decs „Keskeny-erdo” K1a, J6 (Kevey ined.: 1999).

\section{Carduus crispus L.}

Körös-vidék:

9394.3: Gyula „Kutyahelyi-erdő” M3 (Kevey ined.: 2003).

\section{Carduus nutans $\mathrm{L}$.}

Duna-Tisza köze:

9884.1: Kelebia „Nagy-Kéri-erdő” M4 (Kevey \& Lendvai ined.: 2019).

\section{Carpinus betulus L.}

Mezőföld:

8678.4: Martonvásár „Kastély-park” K1a (KevEY 1987: 36). 
Centaurea arenaria M. Bieb. ex Willd.

Nyírség:

8497.4: Vámospércs „Jónás-rész” M4 (Kevey \& Papp ined.: 2019).

Centaurea indurata Janka

Körös-vidék:

8796.3: Hencida „Csere-erdő” M3 (Kevey \& Papp ined.: 2017).

\section{Centaurea jacea $\mathrm{L}$.}

Duna-Tisza köze:

9082.1: Kunbaracs „Búhegyi-erdő” M4 (Kevey \& Urbán ined.: 2020).

Tiszántúl:

8292.4: Újszentmargita „Tilos-erdő” M3 (Kevey \& Molnár A. ined.: 2017).

8391.4: Hortobágy „Ohat-erdő” M3 (Kevey \& Molnár A. ined.: 2016).

Nyírség:

8497.4: Vámospércs „Jónás-rész” M4 (Kevey \& Papp ined.: 2019).

Körös-vidék:

9394.3: Gyula „Kutyahelyi-erdő” M3 (Kevey ined.: 2003).

\section{Centaurea scabiosa L.}

Duna-Tisza köze:

9082.1: Kunbaracs „Búhegyi-erdő” M4 (Kevey \& Urbán ined.: 2020).

Nyírség:

8497.3: Debrecen-Haláp „Álló-hegy” M4 (Kevey \& Papp ined.: 2019).

\section{Centaurea stoebe L.}

Duna-Tisza köze:

9185.1: Nyárlőrinc „Bogárzó-erdő” M4 (Kevey \& Urbán ined.: 2020).

Nyírség:

8597.2: Vámospércs „Bagaméri-erdő” M4 (Kevey \& Papp ined.: 2019).

\section{Centaurium erythraea Raf.}

Duna-Tisza köze:

8782.1: Csévharaszt „Pótharaszti-erdo”” M4 (Kevey \& Urbán ined.: 2020).

Tiszántúl:

8292.4: Újszentmargita „Tilos-erdő” M3 (Kevey \& Molnár A. ined.: 2017).

Centaurium pulchellum (Sw.) Druce

Körös-vidék:

9193.1: Bélmegyer „Szolga-erdő” M3 (Kevey ined.: 2002).

Cephalanthera damasonium (Mill.) Druce

Mezőföld:

9176.2: Dég „a Festetics síremlék és a tó közötti erdőrészben” J6 (KEVEY 1984: 53).

Sárköz:

9679.2: Dusnok „Lenesi-erdo”” J6 (Kevey \& Tóth I. in KEVEY 1990: 92).

Mohácsi-sziget:

9979.3: Dunafalva „Tiser-erdő” K1a, J6 (KeveY 1990: 92).

Cephalanthera longifolia (L.) Fritsch

Mohácsi-sziget:

9979.3: Dunafalva „Tiser-erdo”” K1a (Kevey 1990: 92). 
Cerastium brachypetalum Desp.

Duna-Tisza köze:

8984.1: Nagykőrös „Nagy-erdo”” M4 (Kevey \& Lendvai ined.: 2012).

Tiszántúl:

8292.4: Újszentmargita „Tilos-erdő” M3 (Kevey \& Molnár A. ined.: 2017).

Nyírség:

8299.4: Bátorliget „Fényi-erdő” M4 (Kevey \& Papp ined.: 2020).

8497.3: Debrecen-Haláp „Álló-hegy” M4 (Kevey, Demeter \& Papp ined.: 2019).

8497.4: Vámospércs „Jónás-rész” M4 (Kevey \& Papp ined.: 2019).

8597.2: Vámospércs „Bagaméri-erdő” M4 (Kevey \& Papp ined.: 2019).

\section{Cerastium fontanum agg.}

Jászság:

8686.2: Jászalsószentgyögy „Borsa-erdő” M3 (Kevey \& Urbán ined.: 2017).

Nyírség:

8497.4: Vámospércs „Jónás-rész” M4 (Kevey \& Papp ined.: 2019).

\section{Cerastium semidecandrum L.}

Körös-vidék:

8796.3: Hencida „Csere-erdő” M3 (Kevey \& Papp ined.: 2017).

Cerastium sylvaticum W. et K.

Mezőföld:

9176.2: Dég „Kastély-park” J5 (KeveY 1983: 21).

Villányi-hegység:

0175.2: Bisse „Poszhagymás” K1a (Kevey 1981: 180).

\section{Chaerophyllum bulbosum L.}

Jászság:

8686.1: Jászalsószentgyögy „Borsa-erdő” M3 (Kevey \& Urbán ined.: 2017).

\section{Chaerophyllum temulum $\mathrm{L}$.}

\section{Tiszántúl:}

8292.4: Újszentmargita „Tilos-erdő” M3 (Kevey \& Molnár A. ined.: 2017).

8391.4: Hortobágy „Ohat-erdo” M3 (Kevey \& Molnár A. ined.: 2016).

Körös-vidék:

9394.3: Gyula „Kutyahelyi-erdő” M3 (Kevey ined.: 2003).

\section{Chamaecytisus austriacus (L.) Link}

Duna-Tisza köze:

8782.1: Csévharaszt „Pótharaszti-erdő” M4 (Kevey \& Urbán ined.: 2020).

8882.3: Táborfalva „Lőtér” M5 (Kevey \& Lendvai ined.: 2012).

9185.1: Nyárlőrinc „Bogárzó-erdő” M4 (Kevey \& Urbán ined.: 2020).

Chamaecytisus ratisbonensis (Schaeff.) Rothm.

Duna-Tisza köze:

8981.2: Kunpeszér „Peszéri-erdő” M4 (Kevey \& Urbán ined.: 2019).

Nyírség:

8497.3: Debrecen-Haláp „Álló-hegy” M4 (Kevey, Demeter \& Papp ined.: 2019).

8497.4: Vámospércs „Jónás-rész” M4 (Kevey \& Papp ined.: 2019).

8596.2: Debrecen-Bánk „Kalánhegyi-tölgyes” M4 (Kevey \& Papp ined.: 2019).

8597.2: Vámospércs „Bagaméri-erdő” M4 (Kevey \& Papp ined.: 2019).

\section{Chondrilla juncea L.}

Duna-Tisza köze:

8984.1: Nagykőrös „Nagy-erdo” M4 (Kevey \& Lendvai ined.: 2012); Csemő „Szénásteleki-erdo” M4 (Kevey \& Urbán ined.: 2018).

Nyírség:

8597.2: Vámospércs „Bagaméri-erdő” M4 (Kevey \& Papp ined.: 2019). 


\section{Clematis recta $\mathrm{L}$.}

\section{Csepel-sziget:}

8779.3: Ráckeve „Silling-erdő” J6 (Kevey ined. 1987).

8779.4: Szigetújfalu „Újfalusi-erdő” J6 (Kevey ined. 1987).

8780.1: Szigethalom „Tököli-erdő” J6 (Kevey ined. 1993).

8879.1: Ráckeve „Silling-erdő” J6 (Kevey ined. 1987).

\section{Clematis vitalba L.}

Körös-vidék:

9293.4: Doboz „Papholt-erdő” J6 (Kevey ined.: 2002).

\section{Clinopodium vulgare $\mathrm{L}$.}

Jászság:

8686.2: Jászalsószentgyögy „Borsa-erdő” M3 (Kevey \& Urbán ined.: 2017).

Nyírség:

8497.3: Debrecen-Haláp „Álló-hegy” M4 (Kevey, Demeter \& Papp ined.: 2019).

8596.2: Debrecen-Bánk „Kalánhegyi-tölgyes” M4 (Kevey \& Papp ined.: 2019).

8597.2: Vámospércs „Bagaméri-erdő” M4 (Kevey \& Papp ined.: 2019).

\section{Corispermum canescens Kit.}

Duna-Tisza köze:

8984.1: Nagykőrös „Nagy-erdő” M4 (Kevey \& Lendvai ined.: 2012).

\section{Cornus mas L.}

\section{Mohácsi-sziget:}

0078.4: Kölked „Alsó-Béda” J6 (O.-Kovács in KeveY et al. 1992: 17), „Felső-Béda” J6 (Borhidi in KeveY et al. 1992: 17), „Külső-Béda” J6 (Kevey ined.: 1992), „Bok” J6 (O-Kovács in KEVEY et al. 1992: 17), „Erdőfü” J6 (Deme in KevEY \& TóTH 2000: 135).

0079.3: Hercegszántó „Szarvas-tanya” J6 (Tóth in KeveY et al. 1992: 17), „Sziget-erdő” J6 (Kevey in KEVEY \& TóTH 2000: 135), „Keskeny-erdő” J6 (Kevey ined.: 1993).

\section{Mezőföld:}

8678.4: Martonvásár „Kastély-park” J6 (KEVEY 1987: 39).

8976.4: Soponya-Nagyláng „Kastély-park” J6 (Kevey ined.: 1981), „Fácános-erdő” J6 (Kevey ined.: 1978).

9076.2: Káloz „Belmajor” J6 (Kevey ined.: 1984).

9278.4: Németkér „Barát-erdő” K1a (KevEy 2015b: 23).

9378.1: Bikács-Kistápé „Ökör-hegy” L5 (KEvEY 2015b: 23).

Csepel-sziget:

8779.3: Szigetújfalu „Újfalusi-erdő” J6 (KEVEY 1990: 87).

8879.1: Ráckeve „Silling-erdő” J6 (KEVEY 1990: 87).

\section{Cornus sanguinea $\mathrm{L}$.}

Duna-Tisza köze:

9082.1: Kunbaracs „Búhegyi-erdő” M4 (Kevey \& Urbán ined.: 2020).

\section{Corydalis cava L.}

Csepel-sziget:

8779.3: Ráckeve „Silling-erdő” J6 (KEVEY 1983: 21).

\section{Mezőföld:}

8678.4: Martonvásár „Kastély-park” J6 (KEVEY 1983: 21).

8879.3: Adony „Park-erdő” J6 (Kevey ined.: 1997).

8976.4: Soponya-Nagyláng „Fácános-erdo”” J6 (KeVEy 1983: 21), „Kastély-park” J6 (KevEy 1983: 21).

9377.2: Vajta „Nagy-erdő” K1a (Kevey \& Horvát ined.: 1978). 
Corydalis pumila Rchb.

Mezőföld:

8678.4: Martonvásár „Kastély-park” J6 (KEVEY 1983: 21).

8879.3: Adony „Park-erdő” J6 (Kevey ined.: 1997).

Mecsek:

9876.1: Hosszúhetény „Zengő” K2, K5 (KEVEY 1988: 97).

Corydalis solida (L.) Clairv.

Duna-Tisza köze:

8984.1: Csemő „Szénásteleki-erdő” L5 (Kevey ined.: 2019). Urbán (ined.: 2020) szerint 18 virágzó és 5 meddő példány.

Mezőföld:

8976.4: Soponya-Nagyláng „Kastély-park” K1a, J6 (KeVEY 1983: 21).

Corylus avellana L.

Duna-Tisza köze:

9082.1: Kunbaracs „Búhegyi-erdő” K1a, L5 (Kevey \& Urbán ined.: 2020).

Crataegus laevigata (Poir.) DC.

Keszthelyi-hegység:

9269.2: Gyenesdiás „Büdöskúti-völgy” K2 (Kevey ined.: 1986).

Mohácsi-sziget:

0078.4: Kölked „Alsó-Béda” J6 (Kevey in Kevey \& Tóth I. 2000: 134).

0079.3: Hercegszántó „Szarvastanya” K1a (Kevey in KeveY \& Tóth I. 2000: 134).

Jászság:

8383.1: Verseg-Fenyőharaszt „Kastély-park” J6 (KevEY 1983: 20).

Crepis rhoeadifolia M. Bieb.

Duna-Tisza köze:

9884.1: Kelebia „Nagy-Kéri-erdő” M4 (Kevey \& Lendvai ined.: 2019).

Cruciata glabra (L.) Ehrend.

Nyírség:

8596.2: Debrecen-Bánk „Kalánhegyi-tölgyes” M4 (Kevey \& Papp ined.: 2019).

8597.2: Vámospércs „Bagaméri-erdő” M4 (Kevey \& Papp ined.: 2019).

Cruciata pedemontana (Bellardi) Ehrend.

Duna-Tisza köze:

9083.3: Hetényegyháza „Nagy-Nyíri-erdő” M4 (Kevey \& Urbán ined.: 2020).

Tiszántúl:

8391.4: Hortobágy „Ohat-erdo” M3 (Kevey \& Molnár A. ined.: 2016).

Körös-vidék:

8796.3: Hencida „Csere-erdő” M3 (Kevey \& Papp ined.: 2017).

9394.3: Gyula „Gelvács” M3 (Kevey ined.: 2003).

Nyírség:

8497.4: Vámospércs „Jónás-rész” M4 (Kevey \& Papp ined.: 2019).

\section{Cucubalus baccifer $\mathrm{L}$.}

Jászság:

8686.1: Jászalsószentgyögy „Borsa-erdő” M3 (Kevey \& Urbán ined.: 2017).

Körös-vidék:

8796.3: Hencida „Csere-erdő” M3 (Kevey \& Papp ined.: 2017).

Nyírség:

8596.2: Debrecen-Bánk „Kalánhegyi-tölgyes” M4 (Kevey \& Papp ined.: 2019). 
Cuscuta epithymum (L.) Nath.

Jászság:

8586.3: Alattyán „Berki-erdő” M3 (Kevey \& Urbán ined.: 2018).

Tiszántúl:

8391.4: Hortobágy „Ohat-erdő” M3 (Kevey \& Molnár A. ined.: 2016).

\section{Cyclamen purpurascens Mill.}

Mezőföld:

8678.4: Martonvásár „Kastély-park” J6 (KEVEY et al. 2016: 282).

8976.4: Soponya-Nagyláng „Kastély-park” K1a, J6 (HANGAY 1889; KeVEY 1988: 98).

8977.4: Sárosd „Nagy-erdo” K1a (Kevey ined.: 1997).

9176.2: Dég „Kastély-park: Ördög-domb” K1a, J6 (KeveY 1984: 53).

Mecsek:

9874.3: Bakonya „Sás-völgy” K2 (KEVEY 1990: 89).

Zselic:

9672.3: Szenna „Derék-hegy”! K2 (Juhász ined.: 2007); Bárdudvarnok „Cseberki-erdő”! K2 (Pintér ined.: 1989).

Cynoglossum hungaricum Simonk.

Duna-Tisza köze:

8882.3: Táborfalva „Lőtér” M5 (Kevey \& Lendvai ined.: 2012).

8881.4: Kunpeszér „Rácz-ház” M4 (Kevey \& Urbán ined.: 2020).

8981.2: Kunpeszér „Peszéri-erdő” M4 (Kevey \& Urbán ined.: 2019).

9083.3: Hetényegyháza „Nagy-Nyíri-erdő” M4 (Kevey \& Urbán ined.: 2020).

9185.1: Nyárlőrinc „Bogárzó-erdő” M4 (Kevey \& Urbán ined.: 2020).

9884.1: Kelebia „Nagy-Kéri-erdo”” M4 (Kevey \& Lendvai ined.: 2019).

Nyírség:

8497.3: Debrecen-Haláp „Álló-hegy” M4 (Kevey \& Papp ined.: 2019).

8597.2: Vámospércs „Bagaméri-erdő” M4 (Kevey \& Papp ined.: 2019).

\section{Dianthus armeria L.}

Körös-vidék:

8796.3: Hencida „Csere-erdő” M3 (Kevey \& Papp ined.: 2017).

9193.1: Bélmegyer „Szolga-erdo” M3 (Kevey ined.: 2002).

9293.4: Doboz „Papholt-erdő” M3 (Kevey ined.: 2002).

\section{Dianthus barbatus L.}

Mecsek:

9876.1: Hosszúhetény „Róka-hegy” L2a (KEVEY 1993: 56).

Dianthus collinus Waldst. et Kit.

Nyírség:

8497.4: Vámospércs „Jónás-rész” M4 (Kevey \& Papp ined.: 2019).

\section{Dianthus pontederae A. Kern.}

Körös-vidék:

8796.3: Hencida „Csere-erdő” M3 (Kevey \& Papp ined.: 2017).

Nyírség:

8497.4: Vámospércs „Jónás-rész” M4 (Kevey \& Papp ined.: 2019).

\section{Dictamnus albus L.}

Nyírség:

8497.3: Debrecen-Haláp „Álló-hegy” M4 (Kevey, Demeter \& Papp ined.: 2019).

8597.2: Vámospércs „Bagaméri-erdő” M4 (Kevey \& Papp ined.: 2019).

\section{Digitalis grandiflora Mill.}

Nyírség:

8596.2: Debrecen-Bánk „Kalánhegyi-tölgyes” M4 (Kevey \& Papp ined.: 2019).

8597.2: Vámospércs „Bagaméri-erdő” M4 (Kevey \& Papp ined.: 2019). 
Doronicum hungaricum (Sadler) Rchb. Tiszántúl:

8391.4: Hortobágy „Ohat-erdo” M3 (Kevey \& Molnár A. ined.: 2016).

Dorycnium germanicum (Gremli) Rikli Duna-Tisza köze:

8981.2: Kunpeszér „Peszéri-erdő” M4 (Kevey \& Urbán ined.: 2019).

Diplotaxis tenuifolia (L.) DC. Duna-Tisza köze:

9884.1: Kelebia „Nagy-Kéri-erdő” M4 (Kevey \& Lendvai ined.: 2019).

\section{Erigeron acris L.}

Duna-Tisza köze:

8882.3: Táborfalva „Lőtér” M5 (Kevey \& Lendvai ined.: 2012).

\section{Eryngium campestre L.}

Duna-Tisza köze:

9884.1: Kelebia „Nagy-Kéri-erdő” M4 (Kevey \& Lendvai ined.: 2019).

\section{Erysimum diffusum Ehrh.}

Duna-Tisza köze:

8881.4: Kunpeszér „Rácz-ház” M4 (Kevey \& Urbán ined.: 2020).

8882.3: Táborfalva „Lőtér” M5 (Kevey \& Lendvai ined.: 2012).

Nyírség:

8497.4: Vámospércs „Jónás-rész” M4 (Kevey \& Papp ined.: 2019).

\section{Euonymus verrucosus Scop.}

Mezőföld:

8678.4: Martonvásár „Kastély-park” K1a, J6 (KEvey 1987: 39). 8976.4: Soponya-Nagyláng „Kastély-park” K1a, J6 (KeVEY 1993: 55). 8977.4: Sárosd „Nagy-erdo” K1a (Kevey ined.: 1997).

9176.2: Dég „Kastély-park: Ördög-domb” K1a, J6 (Kevey 1984: 52).

9278.3: Németkér „Barát-erdő” K1a (KevEY 1993: 55); Bikács-Kistápé „Győrimajor melletti erdő” K1a, L5 (Kevey ined.: 1982).

9377.2: Vajta „Nagy-erdő” K1a, L5 (KeVEY 1981: 181).

9378.1: Bikács-Kistápé „Akalacsi-erdő” K1a, L5 (KEVEY 1993: 55); Vajta „Nagy-erdő” K1a, L5 (KEVEY 1981: 181).

9378.3: Nagydorog „Fürdő-erdő” K1a (KeveY 1993: 55), „Banai-erdő” K1a, L5 (KEvEY 1993: 55).

\section{Euphorbia amygdaloides L.}

Bereg-Szatmári-sík:

8002.2: Túrricse „Ricsei-erdő” K1a (Kevey ined.: 2009).

Vasi-hegyhát:

8968.3: Mikosszéplap „Mikosdi-erdő” K1a (Kevey ined.: 1990).

Keszthelyi-hegység:

9269.2: Gyenesdiás „Büdöskúti-völgy” K5 (Kevey ined.: 1986).

Bakonyalja:

8770.4: Bakonypölöske „Kúpi-erdő” J5, K1a (Kevey ined.: 1989).

Baranyai Dráva-sík:

0073.1: Okorág „Okorági-erdő” K1a (KEVEY 1995: 47); Sumony „Sumonyi-erdő” K1a (KeVEY 1995: 47). 0073.3: Kákics „Gesnye” K1a (KeVEY 1995: 47).

Mohácsi-sziget:

0078.4: Homorud „Árok-erdő” J6 (Kevey \& Tóth in KeVEY 1995: 47).

0079.3: Hercegszántó „Szarvastanya” K1a (KEveY 1995: 47).

\section{Mezőföld:}

8976.4: Soponya-Nagyláng „Kastély-park” J6 (KEVEY 1983: 21).

Zákányi-dombok:

9667.3: Őrtilos „Szentmihály-hegy: Horhós” K2, K5 (KeVEY 2008a: 25; KeVEY 2018: 58).

9767.1: Őrtilos „Szentmihály-hegy: Templom-völgy” K2 (KevEY 2008a: 25; KEVEY 2018: 58).

9767.2: Őrtilos „Vasút-oldal: Földvári-hegy” K2 (KEVEY 2008b: 40, 41). 
Euphorbia angulata Jacq. Nyírség:

8597.2: Vámospércs „Bagaméri-erdő” M4 (Kevey \& Papp ined.: 2019).

Euphorbia lucida Waldst. et Kit.

Nyírség:

8597.2: Vámospércs „Bagaméri-erdő” M4 (Kevey \& Papp ined.: 2019).

\section{Euphorbia palustris L.}

Körös-vidék:

9394.3: Gyula „Kutyahelyi-erdő” M3 (Kevey ined.: 2003).

\section{Euphorbia sequieriana Neck.}

Duna-Tisza köze:

9083.3: Hetényegyháza „Nagy-Nyíri-erdő” M4 (Kevey \& Urbán ined.: 2020).

\section{Fagus sylvatica L.}

Mezőföld:

8977.1: Aba-Felsőszentiván „Szentiváni-erdő” J6 (Kevey ined. 1993).

8678.4: Martonvásár „Kastély-park” K1a (Póka in Kevey 1987: 36; Kevey 1987: 36).

9176.2: Dég „Kastély-park: az Ördög-domb közelében” K1a (KEVEY 1984: 53).

Duna-Tisza köze:

8584.3: Szentmártonkáta „a panzió melletti kis erdőben” K1a (Urbán ined. 2010).

\section{Falcaria vulgaris Bernh.}

Duna-Tisza köze:

9884.1: Kelebia „Nagy-Kéri-erdő” M4 (Kevey \& Lendvai ined.: 2019).

\section{Fallopia dumetorum (L.) Holub}

Jászság:

8586.3: Alattyán „Berki-erdő” M3 (Kevey \& Urbán ined.: 2018).

8686.1: Jászalsószentgyögy „Borsa-erdő” M3 (Kevey \& Urbán ined.: 2017).

8686.2: Jászalsószentgyögy „Borsa-erdő” M3 (Kevey \& Urbán ined.: 2017).

Duna-Tisza köze:

8882.3: Táborfalva „Lőtér” M5 (Kevey \& Lendvai ined.: 2012).

9884.1: Kelebia „Nagy-Kéri-erdő” M4 (Kevey \& Lendvai ined.: 2019).

Tiszántúl:

8292.4: Újszentmargita „Tilos-erdő” M3 (Kevey \& Molnár A. ined.: 2017).

8391.4: Hortobágy „Ohat-erdő” M3 (Kevey \& Molnár A. ined.: 2016).

\section{Körös-vidék:}

8796.3: Hencida „Csere-erdő” M3 (Kevey \& Papp ined.: 2017).

9293.4: Doboz „Papholt-erdő” M3 (Kevey ined.: 2002).

9394.3: Gyula „Gelvács” M3 (Kevey ined.: 2003).

Nyírség:

8299.4: Bátorliget „Fényi-erdő” M4 (Kevey \& Papp ined.: 2020).

8497.3: Debrecen-Haláp „Álló-hegy” M4 (Kevey, Demeter \& Papp ined.: 2019).

8596.2: Debrecen-Bánk „Kalánhegyi-tölgyes” M4 (Kevey \& Papp ined.: 2019).

8597.2: Vámospércs „Bagaméri-erdő” M4 (Kevey \& Papp ined.: 2019).

\section{Filipendula vulgaris Moench}

Duna-Tisza köze:

8981.2: Kunpeszér „Peszéri-erdő” M4 (Kevey \& Urbán ined.: 2019).

9082.1: Kunbaracs „Búhegyi-erdő” M4 (Kevey \& Urbán ined.: 2020).

Nyírség:

8497.4: Vámospércs „Jónás-rész” M4 (Kevey \& Papp ined.: 2019).

8596.2: Debrecen-Bánk „Kalánhegyi-tölgyes” M4 (Kevey \& Papp ined.: 2019).

8597.2: Vámospércs „Bagaméri-erdő” M4 (Kevey \& Papp ined.: 2019). 
Fragaria viridis Duchesne

Nyírség:

8299.4: Bátorliget „Fényi-erdő” M4 (Kevey \& Papp ined.: 2020).

Körös-vidék:

9293.4: Doboz „Papholt-erdő” M3 (Kevey ined.: 2002).

\section{Fraxinus ornus L.}

Mezőföld:

8976.4: Soponya-Nagyláng „Kastély-park” K1a (Kevey ined.: 1981).

8977.1: Aba-Felsőszentiván „Szentiváni-erdő” J6 (Kevey ined.: 1993).

Galeopsis bifida Boenn.

Duna-Tisza köze:

8984.1: Nagykőrös „Csókás-erdő” L5 (Kevey \& Lendvai ined.: 2012); Csemő „Szénásteleki-erdő” L5 (Kevey \& Urbán ined.: 2018).

Tiszántúl:

8292.4: Újszentmargita „Tilos-erdő” M3 (Kevey \& Molnár A. ined.: 2017).

Körös-vidék:

9394.3: Gyula „Kutyahelyi-erdő” M3 (Kevey ined.: 2003).

Sárköz:

9779.3: Érsekcsanád „Veránka” J6 (Tóth I. 1958: 110).

9679.3: Őcsény „Keselyűs” J6 (TóTH I. 1958: 110), „Gemenc” J6 (TóTH I. 1958: 110).

9779.1: Decs „Gyöngyös-oldal” K1a, J6 (Kevey \& Tóth I. in Kevey 1993: 56), „Szomfova” K1a, J6 (Kevey

\& Tóth I. in KeVEY 1993: 56).

Belső-Somogy:

9470.4: Marcali „Gyótai-erdő” K1a (KEVEY 1993: 56).

\section{Galeopsis pubescens Besser}

Nyírség:

8497.3: Debrecen-Haláp „Álló-hegy” L5 (Kevey \& Papp ined.: 2019).

8596.2: Debrecen-Bánk „Kalánhegyi-tölgyes” L5 (Kevey \& Papp ined.: 2019).

\section{Galeopsis speciosa Mill.}

Nyírség:

8497.3: Debrecen-Haláp „Álló-hegy” L5 (Kevey, Demeter \& Papp ined.: 2019).

8497.4: Vámospércs „Jónás-rész” M4 (Kevey \& Papp ined.: 2019).

8596.2: Debrecen-Bánk „Kalánhegyi-tölgyes” L5 (Kevey \& Papp ined.: 2019).

8597.2: Vámospércs „Bagaméri-erdő” L5 (Kevey \& Papp ined.: 2019).

\section{Galium boreale L.}

Duna-Tisza köze:

8981.2: Kunpeszér „Peszéri-erdő” M4 (Kevey \& Urbán ined.: 2019).

Nyírség:

8497.4: Vámospércs „Jónás-rész” M4 (Kevey \& Papp ined.: 2019).

8597.2: Vámospércs „Bagaméri-erdő” M4 (Kevey \& Papp ined.: 2019).

\section{Galium glaucum L.}

Körös-vidék:

8796.3: Hencida „Csere-erdő” M3 (Kevey \& Papp ined.: 2017).

\section{Galium mollugo L.}

Nyírség:

8497.4: Vámospércs „Jónás-rész” M4 (Kevey \& Papp ined.: 2019).

8596.2: Debrecen-Bánk „Kalánhegyi-tölgyes” M4 (Kevey \& Papp ined.: 2019). 
Galium odoratum (L.) Scop.

Mezőföld:

8976.4: Soponya-Nagyláng „Kastély-park” K1a, J6 (KeveY 1985: 156).

9278.3: Bikács-Kistápé „Győri-major” K1a (KeveY 1993: 55).

9378.2: Paks „Gyapai-erdő” J6 (LENDVAI in KeveY 1993: 55).

9378.3: Nagydorog „Fürdő-erdő” K1a (KEVEY 1993: 55).

9478.1: Tengelic „Felsőtengelici-erdő” K1a (KEVEY 1993: 55).

Csepel-sziget:

8979.1: Makád „Rókás” J6 (Kevey 1993: 55).

Sárköz:

9678.4: Őcsény „Borrév” J6 (TóTH 1958: 125).

9679.3: Őcsény „Sárosalja” J6 (Tóth in KevEY \& TóTH 2000: 135).

9779.1: Decs „Szomfova” K1a, J6 (Kevey \& TóTH 2000: 135).

9879.1: Báta „Pusztaréti-erdő” (Kevey ined.: 2000).

\section{Galium rubioides $\mathrm{L}$.}

Nyírség:

8597.2: Vámospércs „Bagaméri-erdő” M4 (Kevey \& Papp ined.: 2019).

Körös-vidék:

9394.3: Gyula „Kutyahelyi-erdő” M3 (Kevey ined.: 2003).

\section{Galium verum $\mathrm{L}$.}

Duna-Tisza köze:

9884.1: Kelebia „Nagy-Kéri-erdő” M4 (Kevey \& Lendvai ined.: 2019).

Genista tinctoria L. subsp. elata (Moench) Domin

Duna-Tisza köze:

8981.2: Kunpeszér „Peszéri-erdő” M4 (Kevey \& Urbán ined.: 2019).

9185.1: Nyárlőrinc „Bogárzó-erdő” M4 (Kevey \& Urbán ined.: 2020).

Körös-vidék:

8796.3: Hencida „Csere-erdő” M3 (Kevey \& Papp ined.: 2017).

Nyírség:

8596.2: Debrecen-Bánk „Kalánhegyi-tölgyes” M4 (Kevey \& Papp ined.: 2019).

\section{Geranium columbinum $\mathrm{L}$.}

Duna-Tisza köze:

8984.1: Nagykőrös „Csókás-erdő” M4 (Kevey \& Urbán ined.: 2018).

\section{Geranium phaeum L.}

Mezőföld:

8678.4: Martonvásár „Kastély-park” J6 (Horvát \& Kevey in KevEY 1981: 180).

Sárköz:

9779.1: Decs „Szomfova” J6 (Kevey ined.: 1999).

\section{Geranium robertianum L.}

Duna-Tisza köze:

8984.1: Nagykőrös „Csókás-erdő” L5 (Kevey \& Lendvai ined.: 2012); Csemő „Szénásteleki-erdő” (Kevey \& Urbán ined.: 2018).

Nyírség:

8497.3: Debrecen-Haláp „Álló-hegy” L5 (Kevey, Demeter \& Papp ined.: 2019).

\section{Geranium rotundifolium $\mathrm{L}$.}

Duna-Tisza köze:

9083.3: Hetényegyháza „Nagy-Nyíri-erdő” M4 (Kevey \& Urbán ined.: 2020).

\section{Geranium sanguineum L.}

Nyírség:

8497.3: Debrecen-Haláp „Álló-hegy” M4 (Kevey, Demeter \& Papp ined.: 2019).

8596.2: Debrecen-Bánk „Kalánhegyi-tölgyes” M4 (Kevey \& Papp ined.: 2019).

8597.2: Vámospércs „Bagaméri-erdő” M4 (Kevey \& Papp ined.: 2019). 
Geum urbanum L.

Duna-Tisza köze:

9082.1: Kunbaracs „Búhegyi-erdő” K1a, L5 (Kevey \& Urbán ined.: 2020).

9083.1: Hetényegyháza „Nagy-Nyíri-erdő” L5 (Kevey \& Urbán ined.: 2020).

Nyírség:

8597.2: Vámospércs „Bagaméri-erdo” L5 (Kevey \& Papp ined.: 2019).

Glechoma hirsuta Waldst. et Kit.

Nyírség:

8497.3: Debrecen-Haláp „Álló-hegy” L5 (Kevey \& Papp ined.: 2019).

Globularia punctata Lapeyr.

Duna-Tisza köze:

8981.2: Kunpeszér „Peszéri-erdő” M4 (Kevey \& Urbán ined.: 2019).

Gypsophila arenaria Waldst. et Kit.

Duna-Tisza köze:

8984.1: Nagykőrös „Csókás-erdő” M4 (Kevey \& Urbán ined.: 2018).

Gypsophila muralis L.

Jászság:

8686.1: Jászalsószentgyögy „Borsa-erdő” M3 (Kevey \& Urbán ined.: 2017).

Körös-vidék:

9293.4: Doboz „Papholt-erdő” M3 (Kevey ined.: 2002).

Helianthemum nummularium (L.) Mill.

Duna-Tisza köze:

9082.1: Kunbaracs „Búhegyi-erdő” M4 (Kevey \& Urbán ined.: 2020).

9185.1: Nyárlőrinc „Bogárzó-erdő” M4 (Kevey \& Urbán ined.: 2020).

Nyírség:

8497.3: Debrecen-Haláp „Álló-hegy” M4 (Kevey \& Papp ined.: 2019).

Hepatica nobilis Schreb.

Mezőföld:

8976.4: Soponya-Nagyláng „Kastély-park” K1a (KEvEY 1985: 155).

Hesperis sylvestris Crantz

Tolnai-hegyhát:

9377.1: Kisszékely „Dukai-hegy” (Kevey ined.: 2018).

Hesperis tristis L.

Duna-Tisza köze:

8984.1: Nagykőrös „Csókás-erdő” M4 (Kevey \& Urbán ined.: 2018).

Körös-vidék:

9394.3: Gyula „Gelvács” M3 (Kevey ined.: 2003).

Hieracium bauhini Schult ex Besser

Duna-Tisza köze:

8882.3: Táborfalva „Lőtér” M5 (Kevey \& Lendvai ined.: 2012).

Tiszántúl:

8292.4: Újszentmargita „Tilos-erdő” M3 (Kevey \& Molnár A. ined.: 2017).

Körös-vidék:

9193.1: Bélmegyer „Szolga-erdő” M3 (Kevey ined.: 2002).

Hieracium caespitosum Dumort.

Körös-vidék:

8796.3: Hencida „Csere-erdő” M3 (Kevey \& Papp ined.: 2017). 
Hieracium cymosum L.

Duna-Tisza köze:

8882.3: Táborfalva „Lőtér” M5 (Kevey \& Lendvai ined.: 2012).

\section{Hieracium pilosella L.}

Duna-Tisza köze:

8981.2: Kunpeszér „Peszéri-erdő” M4 (Kevey \& Urbán ined.: 2019).

9083.1: Hetényegyháza „Nagy-Nyíri-erdő” M4 (Kevey \& Urbán ined.: 2020).

\section{Hieracium sabaudum L.}

Duna-Tisza köze:

8782.1: Csévharaszt „Pótharaszti-erdő” M4 (Kevey \& Urbán ined.: 2020).

Tiszántúl:

8391.4: Hortobágy „Ohat-erdo” M3 (Kevey ined.: 2016). Csak pár m²-en egyetlen populáció.

Körös-vidék:

8796.3: Hencida „Csere-erdő” M3 (Kevey \& Papp ined.: 2017).

Mezőföld:

9278.3: Németkér „Barát-erdő” K1a, L5 (KevEy 1988: 98).

9378.1: Bikács-Kistápé „Akalacsi-erdő” K1a, L5 (KEVEY 1988: 98).

\section{Holosteum umbellatum L.}

Duna-Tisza köze:

9083.3: Hetényegyháza „Nagy-Nyíri-erdő” M4 (Kevey \& Urbán ined.: 2020).

Tiszántúl:

8391.4: Hortobágy „Ohat-erdo”” M3 (Kevey \& Molnár A. ined.: 2016).

Körös-vidék:

8796.3: Hencida „Csere-erdő” M3 (Kevey \& Papp ined.: 2017).

Nyírség:

8497.3: Debrecen-Haláp „Álló-hegy” M4 (Kevey \& Papp ined.: 2019).

8497.4: Vámospércs „Jónás-rész” M4 (Kevey \& Papp ined.: 2019).

8597.2: Vámospércs „Bagaméri-erdő” M4 (Kevey \& Papp ined.: 2019).

Hylotelephium telephium (L.) H. Ohba subsp. maximum (L.) H. Ohba

Duna-Tisza köze:

8882.3: Táborfalva „Lőtér” M5 (Kevey \& Lendvai ined.: 2012).

Tiszántúl:

8391.4: Hortobágy „Ohat-erdo” M3 (Kevey \& Molnár A. ined.: 2016).

Körös-vidék:

8796.3: Hencida „Csere-erdő” M3 (Kevey \& Papp ined.: 2017).

9193.1: Bélmegyer „Szolga-erdő” M3 (Kevey ined.: 2002).

Nyírség:

8497.4: Vámospércs „Jónás-rész” M4 (Kevey \& Papp ined.: 2019).

8597.2: Vámospércs „Bagaméri-erdő” M4 (Kevey \& Papp ined.: 2019).

\section{Hypericum hirsutum L.}

Duna-Tisza köze:

8782.1: Csévharaszt „Pótharaszti-erdo” M4 (Kevey \& Urbán ined.: 2020).

Mezőföld:

8976.4: Soponya-Nagyláng „Kastély-park” J6 (KevEy 1988: 97).

9176.2: Dég „Kastély-park: Festetics síremlék közelében” J6 (KEVEY 1984: 52).

\section{Hypericum tetrapterum Fr.}

Jászság:

8686.2: Jászalsószentgyögy „Borsa-erdő” M3 (Kevey \& Urbán ined.: 2017).

Körös-vidék:

9394.3: Gyula „Kutyahelyi-erdő” M3 (Kevey ined.: 2003). 
Impatiens noli-tangere $\mathrm{L}$.

Mezőföld:

8678.4: Martonvásár „Kastély-park” J6 (KEVEY 1985: 155).

Csepel-sziget:

8779.2: Szigetújfalu „Újfalusi-erdő” J4, J6 (KEVEY 2020: 69).

8879.1: Ráckeve „Silling-erdő” J4, J6 (Kevey ined.: 1988).

8879.3: Lórév „Makádi-erdő” J6 (Kevey ined.: 1978); Ráckeve „Besnyő” J4, J6 (KeVEy 2020: 69).

8979.1: Makád „Rókás” J6 (Kevey ined.: 1989).

Sárköz:

9679.3: Öcsény „Keselyűs” J6 (Kevey ined:: 1999).

9779.1: Decs „Szomfova” J6 (Kevey \& Tóth I. ined.: 1999); Érsekcsanád „Veránka” J4, J6 (Kevey \& Tóth I. ined.: 1995).

9779.3: Decs „Keskeny-erdo” J6 (Kevey \& Tóth I. ined.: 1999).

9878.2: Báta „Gyűrűsalj” J4, J6 (Kevey \& Tóth I. ined.: 1997).

9878.4: Báta „Gyürűsalj” J4, J6 (Kevey \& Tóth I. ined.: 1997).

9879.1: Báta „Pusztaréti-erdő” J6 (Kevey ined.: 2000).

Mohácsi-sziget:

0079.3: Hercegszántó-Karapancsa „Szarvastanya” J6 (Kevey in KevEY \& TóTH I. 2018: E1 táblázat), „Sziget-erdő” J6 (Kevey in KevEY \& TóTH I. 2018: E1 táblázat), „Keskeny-erdo”” J6 (Kevey in KevEY \& TóTH I. 2018: E1 táblázat), „Kastély-erdő” J6 (Kevey in KEVEY \& TóTH I. 2018: E1 táblázat).

\section{Inula salicina $\mathrm{L}$.}

Jászság:

8686.1: Jászalsószentgyögy „Borsa-erdő” M3 (Kevey \& Urbán ined.: 2017).

Duna-Tisza köze:

9185.1: Nyárlőrinc „Bogárzó-erdő” M4 (Kevey \& Urbán ined.: 2020).

Tiszántúl:

8292.4: Újszentmargita „Tilos-erdő” M3 (Kevey \& Molnár A. ined.: 2017).

8391.4: Hortobágy „Ohat-erdő” M3 (Kevey \& Molnár A. ined.: 2016).

Nyírség:

8597.2: Vámospércs „Bagaméri-erdő” M4 (Kevey \& Papp ined.: 2019).

\section{Jasione montana L.}

Duna-Tisza köze:

8984.1: Csemő „Szénásteleki-erdô” M4 (Kevey \& Urbán ined.: 2018).

Nyírség:

8497.3: Debrecen-Haláp „Álló-hegy” M4 (Kevey \& Papp ined.: 2019).

Jurinea mollis (L.) Rchb.

Duna-Tisza köze:

8882.3: Táborfalva „Lőtér” M5 (Kevey \& Lendvai ined.: 2012).

8981.2: Kunpeszér „Peszéri-erdő” M4 (Kevey \& Urbán ined.: 2019).

Knautia arvensis (L.) Coult.

Duna-Tisza köze:

9884.1: Kelebia „Nagy-Kéri-erdő” M4 (Kevey \& Lendvai ined.: 2019).

Nyírség:

8497.4: Vámospércs „Jónás-rész” M4 (Kevey \& Papp ined.: 2019).

Koeleria cristata (L.) Pers. em. Borbás ex Domin

Duna-Tisza köze:

9185.1: Nyárlőrinc „Bogárzó-erdő” M4 (Kevey \& Urbán ined.: 2020).

Nyírség:

8497.3: Debrecen-Haláp „Álló-hegy” M4 (Kevey, Demeter \& Papp ined.: 2019).

Koeleria glauca (Spreng.) DC.

Duna-Tisza köze:

8981.2: Kunpeszér „Peszéri-erdő” M4 (Kevey \& Urbán ined.: 2019). 
Lactuca quercina L.

Duna-Tisza köze:

9185.1: Nyárlőrinc „Bogárzó-erdő” M4 (Kevey \& Urbán ined.: 2020).

Tiszántúl:

8391.4: Hortobágy „Ohat-erdo” M3 (Kevey \& Molnár A. ined.: 2016).

Nyírség:

8596.2: Debrecen-Bánk „Kalánhegyi-tölgyes” M4 (Kevey \& Papp ined.: 2019).

8597.2: Vámospércs „Bagaméri-erdő” M4 (Kevey \& Papp ined.: 2019).

\section{Lamium maculatum L.}

Mezőföld:

8678.4: Martonvásár „Kastély-park” J6 (KeveY 1985: 156).

9378.3: Nagydorog „Banai-erdő” K1a (KEVEY 1990: 88).

Csepel-sziget:

8679.2: Érd „Sziget” J6 (Kevey ined.: 1998).

8879.1: Ráckeve „Besnyő = Silling-erdő” J4, J6 (Kevey 1993: 56).

8879.3: Lórév „Makádi-erdo”” J6 (KeVEY 1993: 56).

8979.1: Makád „Rókás” J6 (Kevey 1993: 56).

Sárköz:

9678.2: Szekszárd „Bárányfok” J6 (Kevey ined.: 2018).

9679.3: Őcsény „Felső-Gemenc” J6 (Kevey ined.: 2018), „Keselyűs” J6 (Kevey ined.: 1999).

9779.1: Decs „Szomfova” J6 (Kevey ined.: 1999).

\section{Lathraea squamaria L.}

Csepel-sziget:

8779.2: Szigetújfalu „Újfalusi-erdő” J6 (KEVEY 1990: 88).

8779.3: Ráckeve „Silling-erdő” J6 (KEVEY 1990: 88).

Rábaköz:

8668.2: Kenyeri „Nasici-erdő”6 (Kevey ined.: 2014).

\section{Lathyrus hirsutus L.}

Jászság:

8586.3: Alattyán „Berki-erdő” M3 (Kevey \& Urbán ined.: 2018).

Körös-vidék:

9293.4: Doboz „Papholt-erdő” M3 (Kevey ined.: 2002).

Lathyrus niger (L.) Bernh.

Duna-Tisza köze:

9082.1: Kunbaracs „Búhegyi-erdő” M4 (Kevey ined.: 2015).

\section{Mezőföld:}

9377.2: Vajta „Nagy-erdő” L5 (KEVEY 1981: 181).

9378.1: Vajta „Nagy-erdő” L5 (KEVEY 1981: 181).

Körös-vidék:

8796.3: Hencida „Csere-erdő” M3 (Kevey \& Papp ined.: 2017).

\section{Lathyrus pratensis L.}

Tiszántúl:

8292.4: Újszentmargita „Tilos-erdő” M3 (Kevey \& Molnár A. ined.: 2017).

Nyírség:

8497.4: Vámospércs „Jónás-rész” M4 (Kevey \& Papp ined.: 2019).

\section{Lathyrus sylvestris L.}

Tiszántúl:

8292.4: Újszentmargita „Tilos-erdő” M3 (Kevey \& Molnár A. ined.: 2017).

8391.4: Hortobágy „Ohat-erdő” M3 (Kevey \& Molnár A. ined.: 2016). 
Lathyrus vernus (L.) Bernh. Villányi-hegység:

0176.1: Vokány „Szőlő-hegy=Trinitás-erdő” K2 (Kevey ined.: 1979); Nagytótfalu „Kecskeháti-erdő” K2 (Kevey ined.: 1991); Palkonya „Lucakaréj” K2 (Kevey ined.: 1991).

0176.2: Nagyharsány „Szársomlyó” K2 (Kevey ined.: 1980).

Bereg-Szatmári-sík:

7800.1: Vámosatya „Bockereki-erdő” K1a (Kevey ined.: 2010).

Nyírség:

8199.4: Terem „Nagyfenék” J6 (Kevey ined.: 1994).

Leontodon autumnalis L.

Duna-Tisza köze:

8984.1: Nagykőrös „Nagy-erdő” M4 (Kevey \& Lendvai ined.: 2012).

Leontodon hispidus L.

Duna-Tisza köze:

9083.1: Hetényegyháza „Nagy-Nyíri-erdő” M4 (Kevey \& Urbán ined.: 2020).

Nyírség:

8497.3: Debrecen-Haláp „Álló-hegy” M4 (Kevey, Demeter \& Papp ined.: 2019).

8497.4: Vámospércs „Jónás-rész” M4 (Kevey \& Papp ined.: 2019).

8596.2: Debrecen-Bánk „Kalánhegyi-tölgyes” M4 (Kevey \& Papp ined.: 2019).

\section{Leonurus marrubiastrum L.}

Tiszántúl:

8292.4: Újszentmargita „Tilos-erdő” M3 (Kevey \& Molnár A. ined.: 2017).

8391.4: Hortobágy „Ohat-erdo” M3 (Kevey \& Molnár A. ined.: 2016).

\section{Ligustrum vulgare L.}

Nyírség:

8497.4: Vámospércs „Jónás-rész” M4 (Kevey \& Papp ined.: 2019).

Limonium gmelini (Willd.) Kuntze

Körös-vidék:

8796.3: Hencida „Csere-erdő” M3 (Kevey \& Papp ined.: 2017).

\section{Linaria biebersteinii Besser}

Duna-Tisza köze:

9185.1: Nyárlőrinc „Bogárzó-erdő” M4 (Kevey \& Lendvai ined.: 2020).

Linaria genistifolia (L.) Mill.

Duna-Tisza köze:

8984.1: Nagykőrös „Csókás-erdő” M4 (Kevey \& Urbán ined.: 2018).

9083.3: Hetényegyháza „Nagy-Nyíri-erdő” M4 (Kevey \& Urbán ined.: 2020).

\section{Linum flavum $\mathrm{L}$.}

Duna-Tisza köze:

8984.1: Nagykőrös „Nagy-erdő” M4 (Kevey \& Urbán ined.: 2018).

Listera ovata (L.) R. Br.

Mezőföld:

9176.1: Dég „a Kastély-park Őztelek felőli sarkán” J6 (MAJER 1979: 10; KEVEY 1984: 53).

9378.3: Nagydorog „Banai-erdo” K1a (KEvEY 1990: 92).

\section{Lithospermum officinale L.}

Duna-Tisza köze:

8981.2: Kunpeszér „Peszéri-erdő” M4, M5 (Kevey \& Urbán ined.: 2019).

9082.1: Kunbaracs „Búhegyi-erdő” M4, M5 (Kevey \& Urbán ined.: 2020). 
Lonicera xylosteum L.

Mezőföld:

8678.4: Martonvásár „Kastély-park” J6 (KeVEY 1987: 36).

8976.4: Soponya-Nagyláng „Kastély-park” J6 (KeVEY 1988: 96).

8977.4: Sárosd „Nagy-erdo” K1a (Kevey ined.: 1997).

9076.2: Káloz-Belmajor „Kastély-park” J6 (Kevey ined.: 1984).

\section{Lunaria rediviva $\mathrm{L}$.}

Mezőföld:

8678.4: Martonvásár „Kastély-park” J6 (KEVEY 1983: 21).

Lychnis coronaria (L.) Desr.

Duna-Tisza köze:

9185.1: Nyárlőrinc „Bogárzó-erdő” M4 (Kevey \& Lendvai ined.: 2020).

Nyírség:

8497.3: Debrecen-Haláp „Álló-hegy” M4 (Kevey \& Papp ined.: 2019).

8497.4: Vámospércs „Jónás-rész” M4 (Kevey \& Papp ined.: 2019).

8597.2: Vámospércs „Bagaméri-erdő” M4 (Kevey \& Papp ined.: 2019).

\section{Lychnis flos-cuculi L.}

Tiszántúl:

8391.4: Hortobágy „Ohat-erdo” M3 (Kevey \& Molnár A. ined.: 2016).

Körös-vidék:

8796.3: Hencida „Csere-erdő” M3 (Kevey \& Papp ined.: 2017).

9193.1: Bélmegyer „Szolga-erdo”” M3 (Kevey ined.: 2002).

9293.4: Doboz „Papholt-erdő” M3 (Kevey ined.: 2002).

\section{Lychnis viscaria L.}

Tiszántúl:

8391.4: Hortobágy „Ohat-erdo” M3 (Kevey \& Molnár A. ined.: 2016).

\section{Körös-vidék:}

8796.3: Hencida „Csere-erdő” M3 (Kevey \& Papp ined.: 2017).

Nyírség:

8497.3: Debrecen-Haláp „Álló-hegy” M4 (Kevey, Demeter \& Papp ined.: 2019).

8497.4: Vámospércs „Jónás-rész” M4 (Kevey \& Papp ined.: 2019).

8596.2: Debrecen-Bánk „Kalánhegyi-tölgyes” M4 (Kevey \& Papp ined.: 2019).

8597.2: Vámospércs „Bagaméri-erdő” M4 (Kevey \& Papp ined.: 2019).

\section{Lycopus exaltatus L.}

Tiszántúl:

8391.4: Hortobágy „Ohat-erdo” M3 (Kevey \& Molnár A. ined.: 2016).

\section{Lythrum hyssopifolia L.}

Jászság:

8686.1: Jászalsószentgyögy „Borsa-erdő” M3 (Kevey \& Urbán ined.: 2017).

\section{Lythrum salicaria L.}

Tiszántúl:

8391.4: Hortobágy „Ohat-erdő” M3 (Kevey \& Molnár A. ined.: 2016).

\section{Malus sylvestris (L.) Mill.}

Körös-vidék:

9394.3: Gyula „Kutyahelyi-erdő” M3 (Kevey ined.: 2003).

\section{Marrubium peregrinum L.}

Duna-Tisza köze:

8881.4: Kunpeszér „Rácz-ház” M4 (Kevey \& Urbán ined.: 2020).

Nyírség:

8497.4: Vámospércs „Jónás-rész” M4 (Kevey \& Papp ined.: 2019). 
Medicago falcata L.

Duna-Tisza köze:

8881.4: Kunpeszér „Rácz-ház” M4 (Kevey \& Urbán ined.: 2020).

8882.3: Táborfalva „Lőtér” M5 (Kevey \& Lendvai ined.: 2012).

8984.1: Nagykőrös „Nagy-erdo”" M4 (Kevey \& Lendvai ined.: 2012).

Nyírség:

8597.2: Vámospércs „Bagaméri-erdő” M4 (Kevey \& Papp ined.: 2019).

Körös-vidék:

9193.1: Bélmegyer „Szolga-erdo”” M3 (Kevey ined.: 2002).

\section{Medicago lupulina $\mathrm{L}$.}

Duna-Tisza köze:

8882.3: Táborfalva „Lőtér” M5 (Kevey \& Lendvai ined.: 2012).

\section{Melampyrum cristatum L.}

Duna-Tisza köze:

8981.2: Kunpeszér „Peszéri-erdő” M4 (Kevey \& Urbán ined.: 2019).

9082.1: Kunbaracs „Búhegyi-erdő” M4 (Kevey \& Urbán ined.: 2020).

8983.2: Csemő „Szénásteleki-erdő” M4 (Kevey \& Lendvai ined.: 2012).

8984.1: Nagykőrös „Csókás-erdo”” M4 (Kevey \& Lendvai ined.: 2012).

9185.1: Nyárlőrinc „Bogárzó-erdő” M4 (Kevey \& Urbán ined.: 2020).

Tiszántúl:

8391.4: Hortobágy „Ohat-erdo” M3 (Kevey \& Molnár A. ined.: 2016).

\section{Melampyrum nemorosum $\mathrm{L}$.}

Körös-vidék:

8796.3: Hencida „Csere-erdő” M3 (Kevey \& Papp ined.: 2017).

Nyírség:

8497.3: Debrecen-Haláp „Álló-hegy” L5, M4 (Kevey, Demeter \& Papp ined.: 2019).

8596.2: Debrecen-Bánk „Kalánhegyi-tölgyes” L5, M4 (Kevey \& Papp ined.: 2019).

8597.2: Vámospércs „Bagaméri-erdő” L5, M4 (Kevey \& Papp ined.: 2019).

Melilotus altissimus Thuill.

Körös-vidék:

9293.4: Doboz „Papholt-erdő” M3 (Kevey ined.: 2002).

\section{Melissa officinalis L.}

Zselic:

9773.4: Szágy „Besenczi-erdő” K2 (Kevey ined.: 2020).

Mezőföld:

8976.4: Soponya-Nagyláng „Kastély-park” J6 (KevEY 1985: 156).

Melittis melissophyllum L. subsp. carpatica (Klokov) P.W. BAll. Mezőföld:

8678.4: Martonvásár „Kastély-park” J6 (Kevey 1981: 180).

8976.4: Soponya-Nagyláng „Kastély-park” J6 (KEVEY 1988: 97).

\section{Mercurialis perennis L.}

Mezőföld:

8678.4: Martonvásár „Kastély-park” K1a, J6 (KEVEY 1987: 36).

\section{Mentha aquatica L.}

Körös-vidék:

9394.3: Gyula „Kutyahelyi-erdő” M3 (Kevey ined.: 2003).

\section{Menyanthes trifoliata L.}

Mezőföld:

9278.3: Németkér „a Hardi-ér mentén” (Lendvai in KEVEY 1990: 87). 
Minuartia glomerata (M. Bieb.) Degen

Duna-Tisza köze:

8882.3: Táborfalva „Lőtér” M5 (Kevey \& Lendvai ined.: 2012).

Minuartia setacea (Thuill.) Hayek

Duna-Tisza köze:

8882.3: Táborfalva „Lőtér” M5 (Kevey \& Lendvai ined.: 2012).

Moenchia mantica (L.) Barl.

Duna-Tisza köze:

9082.1: Kunbaracs „Búhegyi-erdő” M4 (Kevey \& Urbán ined.: 2020).

Moehringia trinervia (L.) Clairv.

Tiszántúl:

8292.4: Újszentmargita „Tilos-erdő” M3 (Kevey \& Molnár A. ined.: 2017).

8391.4: Hortobágy „Ohat-erdő” M3 (Kevey \& Molnár A. ined.: 2016).

Nyírség:

8497.3: Debrecen-Haláp „Álló-hegy” L5 (Kevey, Demeter \& Papp ined.: 2019).

8596.2: Debrecen-Bánk „Kalánhegyi-tölgyes” L5 (Kevey \& Papp ined.: 2019).

Körös-vidék:

9394.3: Gyula „Kutyahelyi-erdő” M3 (Kevey ined.: 2003).

\section{Monotropa hypopithis L.}

Keszthelyi-hegység:

9169.1: Rezi „Hosszú-völgy” K2 (Kevey ined.: 1984).

Észak-Zala:

9167.2: Gyűrűs „Kígyós” K2 (Kevey ined.: 1993).

Külső-Somogy:

9475.4: Gyulaj „Garasházi erdészlak” K2 (KEvEY 1985: 156).

Villányi-hegység:

0175.2: Bisse „Remete” K2 (KeVEY 1988: 97; KEVEY 2016: 38).

Dráva-sík:

0073.3: Sumony „Sumonyi-erdo” K1a (KevEY 1990: 89).

Mohácsi-sziget:

0078.3: Kölked „Béda” K1a (HoRvÁT 1977: 44), „Felső-Béda” K1a (Kevey \& Tóth I. in KEvEY et al. 1992: 19; KEVEY \& TóTH 1992: 34).

Mycelis muralis (L.) Dumort.

Nyírség:

8497.4: Vámospércs „Jónás-rész” L5 (Kevey \& Papp ined.: 2019).

Myosotis arvensis (L.) Hill

Jászság:

8686.1: Jászalsószentgyögy „Borsa-erdő” M3 (Kevey \& Urbán ined.: 2017).

Nyírség:

8597.2: Vámospércs „Bagaméri-erdő” M4 (Kevey \& Papp ined.: 2019).

\section{Myosotis ramosissima Rochel}

Jászság:

8586.3: Alattyán „Berki-erdő” M3 (Kevey \& Urbán ined.: 2018).

8686.2: Jászalsószentgyögy „Borsa-erdő” M3 (Kevey \& Urbán ined.: 2017).

Tiszántúl:

8292.4: Újszentmargita „Tilos-erdő” M3 (Kevey \& Molnár A. ined.: 2017).

8391.4: Hortobágy „Ohat-erdő” M3 (Kevey \& Molnár A. ined.: 2016).

Körös-vidék:

9293.4: Doboz „Papholt-erdő” M3 (Kevey ined.: 2002).

9394.3: Gyula „Gelvács” M3 (Kevey ined.: 2003). 
Myosotis sparsiflora J.G. Mikan

Jászság:

8586.3: Alattyán „Berki-erdő” M3 (Kevey \& Urbán ined.: 2018).

8686.2: Jászalsószentgyögy „Borsa-erdő” M3 (Kevey \& Urbán ined.: 2017).

Csepel-sziget:

8879.3: Lórév „Makádi-erdő” J6 (KeVEY 1981: 180).

Myosotis stricta Link

Duna-Tisza köze:

8882.3: Táborfalva „Lőtér” M5 (Kevey \& Lendvai ined.: 2012).

Myosotis sylvatica (Ehrh.) Hoffm.

Mezőföld:

8678.4: Martonvásár „Kastély-park” J6 (KeveY 1983: 21).

Nasturtium officinale R. Br.

Mezőföld:

9176.2: Dég „Kastély-park: a tó mellett” (Boros in KeVEY 1995: 48; MAJER 1984: 65; KevEY 1995: 48).

Nonea pulla (L.) DC.

Duna-Tisza köze:

8981.2: Kunpeszér „Peszéri-erdő” M4 (Kevey \& Urbán ined.: 2019).

Omphalodes scorpioides (Haenke) Schrank

Dráva-sík:

0071.3: Drávaszentes „Szigecske” J4 (Kevey ined.: 2019).

\section{Origanum vulgare L.}

Duna-Tisza köze:

8981.2: Kunpeszér „Peszéri-erdő” M4 (Kevey \& Urbán ined.: 2019).

9082.1: Kunbaracs „Búhegyi-erdő” M4 (Kevey \& Urbán ined.: 2020).

9185.1: Nyárlőrinc „Bogárzó-erdő” M4 (Kevey \& Urbán ined.: 2020).

Nyírség:

8497.3: Debrecen-Haláp „Álló-hegy” M4 (Kevey, Demeter \& Papp ined.: 2019).

8596.2: Debrecen-Bánk „Kalánhegyi-tölgyes” M4 (Kevey \& Papp ined.: 2019).

\section{Orobanche bartlingii Griseb.}

Duna-Tisza köze:

9185.1: Nyárlőrinc „Bogárzó-erdő” M4 (Kevey \& Urbán ined.: 2020).

\section{Orobanche elatior Sutton}

Duna-Tisza köze:

9185.1: Nyárlőrinc „Bogárzó-erdő” M4 (Kevey \& Urbán ined.: 2020).

\section{Padus avium Mill.}

Mezőföld:

8678.4: Martonvásár „Kastély-park” J6 (Kevey 1987: 35).

8976.4: Soponya-Nagyláng „Fácános-erdő” J6 (KEVEY 1983: 20).

\section{Parietaria officinalis L.}

Duna-Tisza köze:

8782.1: Csévharaszt „Pótharaszti-erdo”" L5 (Kevey ined.: 2020).

Mezőföld:

9176.2: Dég „Kastély-park: a Kislángi-árok mentén egy kis folt” J6 (KEVEY 1984: 53).

9377.2: Vajta „Nagy-erdo”” K1a, L5 (KevEY 1985: 157).

Csepel-sziget:

8879.1: Ráckeve „Silling-erdő” J6 (KEVEY 1993: 57).

8879.3: Lórév „Makádi-erdő” J6 (KEVEY 1993: 57).

8979.1: Makád „Rókás” J6 (KEVEY 1993: 57). 
Petrorhagia prolifera (L.) P.W. Ball et Heywood

Duna-Tisza köze:

8984.1: Nagykőrös „Csókás-erdő” M4 (Kevey \& Urbán ined.: 2018).

Nyírség:

8497.4: Vámospércs „Jónás-rész” M4 (Kevey \& Papp ined.: 2019).

Körös-vidék:

9193.1: Bélmegyer „Szolga-erdo”” M3 (Kevey ined.: 2002).

\section{Peucedanum alsaticum L.}

Jászság:

8686.1: Jászalsószentgyögy „Borsa-erdő” M3 (Kevey \& Urbán ined.: 2017).

Duna-Tisza köze:

8981.2: Kunpeszér „Peszéri-erdő” M4 (Kevey \& Urbán ined.: 2019).

8984.1: Nagykőrös „Csókás-erdő” M4 (Kevey \& Urbán ined.: 2018), „Nagy-erdő” M4 (Kevey \& Urbán ined.: 2018); Csemő „Szénásteleki-erdo”” M4 (Kevey \& Urbán ined.: 2018).

Tiszántúl:

8292.4: Újszentmargita „Tilos-erdő” M3 (Kevey \& Molnár A. ined.: 2017).

Peucedanum arenarium Waldst. et Kit.

Duna-Tisza köze:

8782.1: Csévharaszt „Pótharaszti-erdő” M4 (Kevey \& Urbán ined.: 2020).

8882.3: Táborfalva „Lőtér” M5 (Kevey \& Lendvai ined.: 2012).

9185.1: Nyárlőrinc „Bogárzó-erdő” M4 (Kevey \& Urbán ined.: 2020).

\section{Peucedanum cervaria (L.) Lapeyr.}

Duna-Tisza köze:

9082.1: Kunbaracs „Búhegyi-erdő” M4 (Kevey \& Urbán ined.: 2020).

9185.1: Nyárlőrinc „Bogárzó-erdő” M4 (Kevey \& Lendvai ined.: 2020).

\section{Peucedanum officinale $\mathrm{L}$.}

Körös-vidék:

8796.3: Hencida „Csere-erdő” M3 (Kevey \& Papp ined.: 2017).

\section{Peucedanum oreoselinum (L.) Moench}

Nyírség:

8596.2: Debrecen-Bánk „Kalánhegyi-tölgyes” M4 (Kevey \& Papp ined.: 2019).

\section{Phlomis tuberosa L.}

Jászság:

8586.3: Alattyán „Berki-erdő” M3 (Kevey \& Urbán ined.: 2018).

8686.1: Jászalsószentgyögy „Borsa-erdő” M3 (Kevey \& Urbán ined.: 2017).

8686.2: Jászalsószentgyögy „Borsa-erdő” M3 (Kevey \& Urbán ined.: 2017).

\section{Pimpinella saxifraga $\mathrm{L}$.}

Nyírség:

8497.3: Debrecen-Haláp „Álló-hegy” M4 (Kevey \& Papp ined.: 2019).

8497.4: Vámospércs „Jónás-rész” M4 (Kevey \& Papp ined.: 2019).

Körös-vidék:

9193.1: Bélmegyer „Szolga-erdő” M3 (Kevey ined.: 2002).

Podospermum Iaciniatum (L.) DC.

Körös-vidék:

8796.3: Hencida „Csere-erdő” M3 (Kevey \& Papp ined.: 2017).

\section{Polygala comosa Schkuhr}

Nyírség:

8596.2: Debrecen-Bánk „Kalánhegyi-tölgyes” M4 (Kevey \& Papp ined.: 2019). 
Polygonum arenarium Waldst. et Kit.

Nyírség:

8497.3: Debrecen-Haláp „Álló-hegy” M4 (Kevey \& Papp ined.: 2019).

\section{Potentilla alba L.}

Nyírség:

8597.2: Vámospércs „Bagaméri-erdő” M4 (Kevey \& Papp ined.: 2019).

\section{Potentilla arenaria Borkh.}

Duna-Tisza köze:

8881.4: Kunpeszér „Rácz-ház” M4 (Kevey \& Urbán ined.: 2020).

Nyírség:

8497.3: Debrecen-Haláp „Álló-hegy” M4 (Kevey, Demeter \& Papp ined.: 2019). 8497.4: Vámospércs „Jónás-rész” M4 (Kevey \& Papp ined.: 2019).

\section{Potentilla heptaphylla L.}

Duna-Tisza köze:

8981.2: Kunpeszér „Peszéri-erdő” M4 (Kevey \& Urbán ined.: 2019).

9082.1: Kunbaracs „Búhegyi-erdő” M4 (Kevey \& Urbán ined.: 2020).

9185.1: Nyárlőrinc „Bogárzó-erdő” M4 (Kevey \& Urbán ined.: 2020).

Tiszántúl:

8391.4: Hortobágy „Ohat-erdo” M3 (Kevey \& Molnár A. ined.: 2016).

Nyírség:

8596.2: Debrecen-Bánk „Kalánhegyi-tölgyes” M4 (Kevey \& Papp ined.: 2019).

8597.2: Vámospércs „Bagaméri-erdő” M4 (Kevey \& Papp ined.: 2019).

\section{Potentilla recta L.}

Duna-Tisza köze:

9185.1: Nyárlőrinc „Bogárzó-erdő” M4 (Kevey \& Urbán ined.: 2020).

\section{Primula veris $\mathrm{L}$.}

Nyírség:

8497.3: Debrecen-Haláp „Álló-hegy” M4 (Kevey, Demeter \& Papp ined.: 2019).

8596.2: Debrecen-Bánk „Kalánhegyi-tölgyes” M4 (Kevey \& Papp ined.: 2019).

\section{Mezőföld:}

8976.4: Soponya-Nagyláng „Kastély-park” J6 (KeVEY 1983: 21).

Csepel-sziget:

8780.1: Szigethalom „Tököli-erdő” J6 (KEvEY 1995: 49).

Primula vulgaris Huds.

Dráva-sík:

9972.1: Merenye „Meggyes-erdő” J5, K1a (Kevey ined.: 1999).

Mezőföld:

8976.4: Soponya-Nagyláng „Kastély-park” J6, K1a (KEVEY 1985: 157).

\section{Pseudolysimachion incanum (L.) Holub}

Nyírség:

8497.3: Debrecen-Haláp „Álló-hegy” M4 (Kevey, Demeter \& Papp ined.: 2019). 8597.2: Vámospércs „Bagaméri-erdő” M4 (Kevey \& Papp ined.: 2019).

\section{Pseudolysimachion longifolium (L.) Opiz}

Nyírség:

8597.2: Vámospércs „Bagaméri-erdő” M4 (Kevey \& Papp ined.: 2019). 
Pseudolysimachion spicatum (L.) Opiz

Duna-Tisza köze:

8981.2: Kunpeszér „Peszéri-erdő” M4 (Kevey \& Urbán ined.: 2019).

9083.1: Hetényegyháza „Nagy-Nyíri-erdő” M4 (Kevey \& Urbán ined.: 2020).

9083.3: Hetényegyháza „Nagy-Nyíri-erdő” M4 (Kevey \& Urbán ined.: 2020).

9185.1: Nyárlőrinc „Bogárzó-erdő” M4 (Kevey \& Urbán ined.: 2020).

9884.1: Kelebia „Nagy-Kéri-erdő” M4 (Kevey \& Lendvai ined.: 2019).

Tiszántúl:

8391.4: Hortobágy „Ohat-erdő” M3 (Kevey \& Molnár A. ined.: 2016).

Nyírség:

8497.3: Debrecen-Haláp „Álló-hegy” M4 (Kevey \& Papp ined.: 2019).

8596.2: Debrecen-Bánk „Kalánhegyi-tölgyes” M4 (Kevey \& Papp ined.: 2019).

8597.2: Vámospércs „Bagaméri-erdő” M4 (Kevey \& Papp ined.: 2019).

Pulmonaria mollissima A. Kern.

Tiszántúl:

8391.4: Hortobágy „Ohat-erdő” M3 (Kevey \& Molnár A. ined.: 2016).

Nyírség:

8497.3: Debrecen-Haláp „Álló-hegy” M4 (Kevey, Demeter \& Papp ined.: 2019).

8596.2: Debrecen-Bánk „Kalánhegyi-tölgyes” M4 (Kevey \& Papp ined.: 2019).

8597.2: Vámospércs „Bagaméri-erdő” M4 (Kevey \& Papp ined.: 2019).

\section{Pulmonaria officinalis $\mathrm{L}$.}

Mezőföld:

8678.4: Martonvásár „Kastély-park” J6, K1a (KevEY 1981: 180).

8976.4: Soponya-Nagyláng „Kastély-park” J6, K1a (KeveY 1985: 156).

9278.3: Németkér „Körtvélyesi-erdő” L5 (Kevey in KEvEY \& LENDVAI 2015: 23), Barát-erdő” L5 (Kevey

in KeVEY \& LeNDVAI 2015: 23).

Pulsatilla flavescens (Hazsl.) Borbás

Nyírség:

8299.4: Bátorliget „Fényi-erdő” M4 (Papp ined.: 2020).

\section{Pyrola rotundifolia $\mathrm{L}$.}

Nyírség:

8597.2: Vámospércs „Bagaméri-erdő” M4 (Kevey \& Papp ined.: 2019).

Pyrus pyraster (L.) Burgsd.

Nyírség:

8597.2: Vámospércs „Bagaméri-erdő” M4 (Kevey \& Papp ined.: 2019).

Körös-vidék:

9394.3: Gyula „Kutyahelyi-erdő” M3 (Kevey ined.: 2003).

\section{Ranunculus acris L.}

Körös-vidék:

8796.3: Hencida „Csere-erdo”" M3 (Kevey \& Papp ined.: 2017).

\section{Ranunculus auricomus agg.}

Duna-Tisza köze:

8984.1: Nagykőrös „Nagy-erdő” L5 (Kevey \& Urbán ined.: 2018).

\section{Ranunculus ficaria L.}

Jászság:

8586.3: Alattyán „Berki-erdő” M3 (Kevey \& Urbán ined.: 2018).

8686.1: Jászalsószentgyögy „Borsa-erdő” M3 (Kevey \& Urbán ined.: 2017).

8686.2: Jászalsószentgyögy „Borsa-erdő” M3 (Kevey \& Urbán ined.: 2017).

Tiszántúl:

8391.4: Hortobágy „Ohat-erdő” M3 (Kevey \& Molnár A. ined.: 2016).

\section{Körös-vidék:}

8796.3: Hencida „Csere-erdo”” M3 (Kevey \& Papp ined.: 2017).

9293.4: Doboz „Papholt-erdő” M3 (Kevey ined.: 2002). 
Ranunculus polyanthemos $\mathrm{L}$.

Duna-Tisza köze:

8981.2: Kunpeszér „Peszéri-erdő” M4 (Kevey \& Urbán ined.: 2019).

9082.1: Kunbaracs „Búhegyi-erdő” M4 (Kevey \& Urbán ined.: 2020).

Tiszántúl:

8292.4: Újszentmargita „Tilos-erdő” M3 (Kevey \& Molnár A. ined.: 2017).

Nyírség:

8497.3: Debrecen-Haláp „Álló-hegy” M4 (Kevey, Demeter \& Papp ined.: 2019).

8497.4: Vámospércs „Jónás-rész” M4 (Kevey \& Papp ined.: 2019).

8596.2: Debrecen-Bánk „Kalánhegyi-tölgyes” M4 (Kevey \& Papp ined.: 2019).

8597.2: Vámospércs „Bagaméri-erdő” M4 (Kevey \& Papp ined.: 2019).

Ranunculus polyphyllus Waldst. et Kit.

Tiszántúl:

8391.4: Hortobágy „Ohat-erdő” M3 (Kevey \& Molnár A. ined.: 2016).

\section{Rhamnus catharticus L.}

Nyírség:

8597.2: Vámospércs „Bagaméri-erdő” M4 (Kevey \& Papp ined.: 2019).

Körös-vidék:

9394.3: Gyula „Kutyahelyi-erdő” M3 (Kevey ined.: 2002).

\section{Ribes rubrum L.}

Tornai-karszt:

7490.3: Bódvarákó „Az Esztrámos és a Kis-hegy között” J5 (Kevey ined.: 1994).

Nyírség:

8596.2: Debrecen-Bánk „Kalánhegyi-tölgyes” L5 (Kevey \& Papp ined.: 2019).

Mezőföld:

9176.2: Dég „Kastély-park” J6 (KEVEY 1984: 52).

\section{Ribes uva-crispa L.}

Körös-vidék:

8796.3: Hencida „Csere-erdő” M3 (Kevey \& Papp ined.: 2017).

Mezőföld:

8678.4: Martonvásár „Kastély-park” J6 (KEVEY 1983: 20).

8778.2: Ráckeresztúr „Baracskai-erdő” J6 (Kevey ined.: 1997).

8976.4: Soponya-Nagyláng „Kastély-park” J6 (KEVEY 1985: 155).

8978.1: Szabadegyháza „Középpusztai-erdő” J6 (Kevey ined.: 1997).

9176.2: Dég „Kastély-park” J6 (KevEY 1984: 52).

\section{Rorippa amphibia (L.) Besser}

Tiszántúl:

8292.4: Újszentmargita „Tilos-erdő” M3 (Kevey \& Molnár A. ined.: 2017).

Rosa dumalis Bechst.

Körös-vidék:

8796.3: Hencida „Csere-erdő” M3 (Kevey \& Papp ined.: 2017).

\section{Rosa gallica L.}

Jászság:

8686.2: Jászalsószentgyögy „Borsa-erdő” M3 (Kevey \& Urbán ined.: 2017).

Körös-vidék:

8796.3: Hencida „Csere-erdő” M3 (Kevey \& Papp ined.: 2017).

\section{Rumex acetosa L.}

Körös-vidék:

8796.3: Hencida „Csere-erdő” M3 (Kevey \& Papp ined.: 2017).

9394.3: Gyula „Kutyahelyi-erdő” M3 (Kevey ined.: 2003).

Nyírség:

8597.2: Vámospércs „Bagaméri-erdő” M4 (Kevey \& Papp ined.: 2019).

8497.4: Vámospércs „Jónás-rész” M4 (Kevey \& Papp ined.: 2019). 
Rumex acetosella L.

Duna-Tisza köze:

9083.1: Hetényegyháza „Nagy-Nyíri-erdő” M4 (Kevey \& Urbán ined.: 2020).

9083.3: Hetényegyháza „Nagy-Nyíri-erdő” M4 (Kevey \& Urbán ined.: 2020).

Rumex crispus L.

Jászság:

8586.3: Alattyán „Berki-erdő” M3 (Kevey \& Urbán ined.: 2018).

\section{Rumex patientia L.}

Jászság:

8686.2: Jászalsószentgyögy „Borsa-erdő” M3 (Kevey \& Urbán ined.: 2017).

\section{Rumex pseudonatronatus Borbás}

Jászság:

8686.2: Jászalsószentgyögy „Borsa-erdő” M3 (Kevey \& Urbán ined.: 2017).

\section{Rumex sanguineus L}

Tiszántúl:

8292.4: Újszentmargita „Tilos-erdő” M3 (Kevey \& Molnár A. ined.: 2017).

8391.4: Hortobágy „Ohat-erdo” M3 (Kevey \& Molnár A. ined.: 2016).

Körös-vidék:

8796.3: Hencida „Csere-erdő” M3 (Kevey \& Papp ined.: 2017).

Salsola kali L.

Duna-Tisza köze:

9083.3: Hetényegyháza „Nagy-Nyíri-erdő” M4 (Kevey \& Urbán ined.: 2020).

\section{Salvia pratensis L.}

Nyírség:

8497.3: Debrecen-Haláp „Álló-hegy” M4 (Kevey, Demeter \& Papp ined.: 2019).

\section{Sanguisorba officinalis L.}

Nyírség:

8497.4: Vámospércs „Jónás-rész” M4 (Kevey \& Papp ined.: 2019).

\section{Sanicula europaea L.}

Mezőföld:

9176.2: Dég „Kastély-park: a Festetics síremlék közelében” J6 (KEVEY 1983: 20; KEVEY 1984: 52).

\section{Saxifraga bulbifera L.}

Tiszántúl:

8391.4: Hortobágy „Ohat-erdo” M3 (Kevey \& Molnár A. ined.: 2016).

Körös-vidék:

8796.3: Hencida „Csere-erdő” M3 (Kevey \& Papp ined.: 2017).

Nyírség:

8497.4: Vámospércs „Jónás-rész” M4 (Kevey \& Papp ined.: 2019).

Scabiosa canescens Waldst. et Kit.

Duna-Tisza köze:

8782.1: Csévharaszt „Pótharaszti-erdő” M4 (Kevey \& Urbán ined.: 2020).

\section{Scabiosa ochroleuca L.}

Duna-Tisza köze:

8881.4: Kunpeszér „Rácz-ház” M4 (Kevey \& Urbán ined.: 2020).

8981.2: Kunpeszér „Peszéri-erdő” M4 (Kevey \& Urbán ined.: 2019).

Nyírség:

8497.4: Vámospércs „Jónás-rész” M4 (Kevey \& Papp ined.: 2019). 
Scorzonera purpurea L.

Duna-Tisza köze:

9083.3: Hetényegyháza „Nagy-Nyíri-erdő” M4 (Kevey \& Urbán ined.: 2020).

\section{Scrophularia nodosa L.}

Duna-Tisza köze:

8782.1: Csévharaszt „Pótharaszti-erdo” L5 (Kevey \& Urbán ined.: 2020).

Tiszántúl:

8391.4: Hortobágy „Ohat-erdo” M3 (Kevey \& Molnár A. ined.: 2016).

Körös-vidék:

8796.3: Hencida „Csere-erdő” M3 (Kevey \& Papp ined.: 2017).

\section{Scrophularia vernalis L.}

Szekszárdi-dombság:

9677.4: Szekszárd „Fazekas-völgy” K5 (KeveY 1993: 56).

Geresdi-dombság:

9777.4: Bátaapáti „Apáti-erdő” (Tóth I. Zs. in KEVEY 1995: 47).

\section{Scutellaria hastifolia L.}

Duna-Tisza köze:

8981.2: Kunpeszér „Peszéri-erdő” M4 (Kevey \& Urbán ined.: 2019).

9082.1: Kunbaracs „Búhegyi-erdő” M4 (Kevey \& Urbán ined.: 2020).

Tiszántúl:

8391.4: Hortobágy „Ohat-erdo”" M3 (Kevey \& Molnár A. ined.: 2016).

Körös-vidék:

8796.3: Hencida „Csere-erdő” M3 (Kevey \& Papp ined.: 2017).

Nyírség:

8497.4: Vámospércs „Jónás-rész” M4 (Kevey \& Papp ined.: 2019).

8596.2: Debrecen-Bánk „Kalánhegyi-tölgyes” M4 (Kevey \& Papp ined.: 2019).

Sedum urvillei DC. subsp. hillebrandtii (Fenzl) D.A. Webb

Duna-Tisza köze:

8981.2: Kunpeszér „Peszéri-erdő” M4 (Kevey \& Urbán ined.: 2019).

\section{Senecio doria Nath.}

Jászság:

8586.3: Alattyán „Berki-erdő” M3 (Kevey \& Urbán ined.: 2018).

Senecio erraticus Bertol.

Körös-vidék:

8796.3: Hencida „Csere-erdő” M3 (Kevey \& Papp ined.: 2017).

\section{Senecio erucifolius L.}

Körös-vidék:

9394.3: Gyula „Gelvács” M3 (Kevey ined.: 2003).

\section{Senecio jacobaea L.}

Duna-Tisza köze:

8882.3: Táborfalva „Lőtér” M5 (Kevey \& Lendvai ined.: 2012).

8981.2: Kunpeszér „Peszéri-erdő” M4 (Kevey \& Urbán ined.: 2019).

9082.1: Kunbaracs „Búhegyi-erdő” M4 (Kevey \& Urbán ined.: 2020).

Nyírség:

8497.3: Debrecen-Haláp „Álló-hegy” M4 (Kevey, Demeter \& Papp ined.: 2019). 
Senecio nemorensis L. S. l.

Mohácsi-sziget:

0078.4: Homorúd „Kormos-erdő” J6 (Kevey ined.: 2004).

Észak-Zala:

9168.3: Nagykapornak „Remete-völgy” J5 (Kevey ined.: 1993).

Zákányi-dombok:

9767.2: Zákány „Vasút-oldal: Hagymás” K2 (Kevey ined.: 1981).

Zselic:

9774.1: Baranyajenő „Kósa-gödör” K1a (Kevey ined.: 1990).

9774.3: Palé „Nagy-hegy” K2 (Kevey ined.: 1989).

\section{Serratula tinctoria L.}

Tiszántúl:

8391.4: Hortobágy „Ohat-erdo”" M3 (Kevey \& Molnár A. ined.: 2016).

Körös-vidék:

8796.3: Hencida „Csere-erdő” M3 (Kevey \& Papp ined.: 2017).

9293.4: Doboz „Papholt-erdő” M3 (Kevey ined.: 2002).

Nyírség:

8497.4: Vámospércs „Jónás-rész” M4 (Kevey \& Papp ined.: 2019).

8596.2: Debrecen-Bánk „Kalánhegyi-tölgyes” M4 (Kevey \& Papp ined.: 2019).

\section{Seseli annuum L.}

Duna-Tisza köze:

8981.2: Kunpeszér „Peszéri-erdő” M4 (Kevey \& Urbán ined.: 2019).

9082.1: Kunbaracs „Búhegyi-erdő” M4 (Kevey \& Urbán ined.: 2020).

9083.1: Hetényegyháza „Nagy-Nyíri-erdő” M4 (Kevey \& Urbán ined.: 2020).

9185.1: Nyárlőrinc „Bogárzó-erdő” M4 (Kevey \& Urbán ined.: 2020).

Seseli varium Trevir.

Nyírség:

8497.3: Debrecen-Haláp „Álló-hegy” M4 (Kevey, Demeter \& Papp ined.: 2019).

Silene multiflora (Waldst. et Kit.) Pers.

Nyírség:

8596.2: Debrecen-Bánk „Kalánhegyi-tölgyes” M4 (Kevey \& Papp ined.: 2019).

\section{Silene noctiflora L.}

Körös-vidék:

9394.3: Gyula „Kutyahelyi-erdő” M3 (Kevey ined.: 2003).

\section{Silene nutans $\mathrm{L}$.}

Duna-Tisza köze:

8981.2: Kunpeszér „Peszéri-erdő” M4 (Kevey \& Urbán ined.: 2019).

9082.1: Kunbaracs „Búhegyi-erdő” M4 (Kevey \& Urbán ined.: 2020).

9884.1: Kelebia „Nagy-Kéri-erdő” M4 (Kevey \& Lendvai ined.: 2019).

Nyírség:

8497.3: Debrecen-Haláp „Álló-hegy” M4 (Kevey, Demeter \& Papp ined.: 2019).

8596.2: Debrecen-Bánk „Kalánhegyi-tölgyes” M4 (Kevey \& Papp ined.: 2019).

Silene otites (L.) Wibel

Duna-Tisza köze:

9083.3: Hetényegyháza „Nagy-Nyíri-erdő” M4 (Kevey \& Urbán ined.: 2020).

Silene viscosa (L.) Pers.

Duna-Tisza köze:

8882.3: Táborfalva „Lőtér” M5 (Kevey \& Lendvai ined.: 2012). 
Smyrnium perfoliatum L.

Mezőföld:

9075.3: Enying „Kustyán-erdő” J6 (Kevey ined.: 2011).

\section{Solidago virgaurea $\mathrm{L}$.}

Nyírség:

8497.3: Debrecen-Haláp „Álló-hegy” M4 (Kevey, Demeter \& Papp ined.: 2019).

8596.2: Debrecen-Bánk „Kalánhegyi-tölgyes” M4 (Kevey \& Papp ined.: 2019).

Sorbus torminalis (L.) Crantz

Mezőföld:

9176.2: Dég „Ördög-domb” J6 (KeVEY 1984: 52).

\section{Spergula arvensis L.}

Nyírség:

8596.2: Debrecen-Bánk „Kalánhegyi-tölgyes” M4 (Kevey \& Papp ined.: 2019).

Spiranthes spiralis (L.) ChevAll.

Tolnai-hegyhát:

9476.4: Szakadát „Rőzse-hegy” H5a (Lukácsi in KevEY 1990: 92).

\section{Stachys recta L.}

Duna-Tisza köze:

8981.2: Kunpeszér „Peszéri-erdo”” M4 (Kevey \& Urbán ined.: 2019).

9083.3: Hetényegyháza „Nagy-Nyíri-erdő” M4 (Kevey \& Urbán ined.: 2020).

9185.1: Nyárlőrinc „Bogárzó-erdő” M4 (Kevey \& Urbán ined.: 2020).

Nyírség:

8497.3: Debrecen-Haláp „Álló-hegy” M4 (Kevey, Demeter \& Papp ined.: 2019).

\section{Stachys sylvatica L.}

\section{Mezőföld:}

8678.4: Martonvásár „Kastély-park” J6 (Kevey 1986: 38).

8976.4: Soponya-Nagyláng „Kastély-park” J6 (Kevey ined.: 1981).

9176.2: Dég „Kastély-park: Ördög-domb” J6, K1a (KEVEY 1984: 52).

9478.1: Tengelic „Felsőtengelici-erdő” L5 (KEVEY 1990: 88).

8977.4: Sárosd „Nagy-erdo”” K1a (Kevey ined.: 1997).

Csepel-sziget:

8779.3: Szigetújfalu „Újfalusi-erdő” J4, J6 (Kevey ined.: 1987); Ráckeve „Silling-erdő” J4, J6 (KEVEY 1990: 86).

8779.4: Szigetújfalu „Újfalusi-erdő” J4, J6 (Kevey ined.: 1987).

8879.1: Ráckeve „Besnyő” J4, J6 (Kevey ined.: 1987).

8979.1: Makád „Rókás” J6 (Kevey ined.: 1989).

Sárköz:

9678.2: Szekszárd „Bárányfok” J6 (Kevey ined.: 2018).

9679.3: Őcsény „Felső-Gemenc” J6 (Kevey ined.: 2018).

9679.4: Sükösd „Karaszi-erdő” J6 (Kevey \& Tóth I. ined.: 1998).

9779.1: Decs „Szomfova” K1a, J6 (Kevey \& Tóth I. ined.: 1988), „Gyöngyös-oldal” K1a, J6 (Kevey \& Tóth I. ined.: 1988).

9779.3: Decs „Keskeny-erdő” J6 (Kevey ined.: 1999).

9879.1: Báta „Pusztaréti-erdő” J6 (Kevey ined.: 2000).

\section{Staphylea pinnata L.}

Tiszántúl:

8391.4: Hortobágy „Ohati-erdő” (Kevey \& Papp ined.: 2017).

Mezőföld:

8678.4: Martonvásár „Kastély-park” J6 (KeveY 1983: 20).

8976.4: Soponya-Nagyláng „Kastély-park” K1a, J6 (Kevey ined.: 1981).

Csepel-sziget:

8779.3: Ráckeve „Silling-erdő” J6 (KEVEY 1990: 86). 
Stellaria graminea L.

Jászság:

8586.3: Alattyán „Berki-erdő” M3 (Kevey \& Urbán ined.: 2018).

Duna-Tisza köze:

9083.1: Hetényegyháza „Nagy-Nyíri-erdő” M4 (Kevey \& Urbán ined.: 2020).

Nyírség:

8597.2: Vámospércs „Bagaméri-erdő” M4 (Kevey \& Papp ined.: 2019).

\section{Stellaria holostea L.}

Bereg-Szatmári-sík:

7701.3: Beregdaróc „Közös-erdő=Dédai-erdő” K1a (Kevey ined.: 2003).

Komáromi-síkság:

8373.1: Bőnyrétalap „Bőnyi-erdő K1a (Kevey ined.: 2005).

Rábaköz:

8668.1: Uraiújfalu „Kőréti-erdő” K1a (Kevey ined.: 2014).

8668.2: Kenyeri „Nasici-erdo”” K1a (Kevey ined.: 2004).

Mezőföld:

9278.4: Németkér „Barát-erdő” K1a (KEVEY 1988: 98).

9377.2: Vajta „Nagy-erdő” K1a (Lendvai in KEVEY \& LENDVAI 2015: 23).

9378.1: Németkér „Ruzsik-erdő” K1a (KEVEY \& LENDVAI 2015: 23).

Sárköz:

9879.1: Báta „Pusztaréti-erdő” J6 (STETÁK 2000: 170).

Symphytum tuberosum L.

Mezőföld:

9176.2: Dég „Kastély-park” J6 (Kevey 1981: 180).

Duna-Tisza köze:

9082.1: Kunbaracs „Búhegyi-erdő” K1a (Kevey 2015a: 46).

Velencei-hegység:

8777.2: Nadap „Bükk-hang” K2 (Kevey et al. 2014: 231); Lovasberény „Templom-hegy és Antónia-hegy között” K2 (KEvEY et al. 2014: 231), „Hársas-tető és Mária-völgy között” K2 (KeVEY et al. 2014: 231).

\section{Taraxacum laevigatum agg.}

Duna-Tisza köze:

8882.3: Táborfalva „Lőtér” M5 (Kevey \& Lendvai ined.: 2012).

8984.1: Nagykőrös „Csókás-erdő” M4 (Kevey \& Urbán ined.: 2018), „Nagy-erdő” M4 (Kevey \& Lendvai ined.: 2012); Csemő „Szénásteleki-erdő” M4 (Kevey \& Lendvai ined.: 2012).

\section{Tephroseris integrifolia (L.) Holub}

Duna-Tisza köze:

8981.2: Kunpeszér „Peszéri-erdő” M4 (Kevey \& Urbán ined.: 2019).

9083.1: Hetényegyháza „Nagy-Nyíri-erdő” M4 (Kevey \& Urbán ined.: 2020).

9083.3: Hetényegyháza „Nagy-Nyíri-erdő” M4 (Kevey \& Urbán ined.: 2020).

Nyírség:

8497.3: Debrecen-Haláp „Álló-hegy” M4 (Kevey, Demeter \& Papp ined.: 2019).

\section{Teucrium chamaedrys L.}

Duna-Tisza köze:

8981.2: Kunpeszér „Peszéri-erdő” M4 (Kevey \& Urbán ined.: 2019).

9884.1: Kelebia „Nagy-Kéri-erdő” M4 (Kevey \& Lendvai ined.: 2019).

Nyírség:

8596.2: Debrecen-Bánk „Kalánhegyi-tölgyes” L5 (Kevey \& Papp ined.: 2019).

\section{Thalictrum aquilegiifolium $\mathrm{L}$.}

Nyírség:

8497.3: Debrecen-Haláp „Álló-hegy” M4 (Kevey, Demeter \& Papp ined.: 2019).

8597.2: Vámospércs „Bagaméri-erdő” M4 (Kevey \& Papp ined.: 2019). 


\section{Thalictrum lucidum L.}

Jászság:

8686.2: Jászalsószentgyögy „Borsa-erdő” M3 (Kevey \& Urbán ined.: 2017).

Duna-Tisza köze:

9082.1: Kunbaracs „Búhegyi-erdő” M4 (Kevey \& Urbán ined.: 2020).

\section{Thalictrum minus $\mathrm{L}$.}

Duna-Tisza köze:

8782.1: Csévharaszt „Pótharaszti-erdő” M4 (Kevey \& Urbán ined.: 2020).

8981.2: Kunpeszér „Peszéri-erdő” M4 (Kevey \& Urbán ined.: 2019).

9083.3: Hetényegyháza „Nagy-Nyíri-erdő” M4 (Kevey \& Urbán ined.: 2020).

Nyírség:

8497.3: Debrecen-Haláp „Álló-hegy” M4 (Kevey, Demeter \& Papp ined.: 2019).

\section{Thalictrum simplex $\mathrm{L}$.}

Jászság:

8686.1: Jászalsószentgyögy „Borsa-erdő” M3 (Kevey \& Urbán ined.: 2017).

\section{Thesium linophyllon L.}

\section{Duna-Tisza köze:}

8981.2: Kunpeszér „Peszéri-erdő” M4 (Kevey \& Urbán ined.: 2019).

8984.1: Nagykőrös „Csókás-erdő” M4 (Kevey \& Lendvai ined.: 2012), „Nagy-erdő” M4 (Kevey \& Urbán ined.: 2018); Csemő „Szénásteleki-erdo”” M4 (Kevey \& Urbán ined.: 2018).

9185.1: Nyárlőrinc „Bogárzó-erdő” M4 (Kevey \& Urbán ined.: 2020).

Nyírség:

8497.3: Debrecen-Haláp „Álló-hegy” M4 (Kevey, Demeter \& Papp ined.: 2019).

\section{Thesium ramosum Hayne}

Duna-Tisza köze:

8882.3: Táborfalva „Lőtér” M5 (Kevey \& Lendvai ined.: 2012).

8981.2: Kunpeszér „Peszéri-erdő” M4 (Kevey \& Urbán ined.: 2019).

8984.1: Nagykőrös „Nagy-erdő” M4 (Kevey \& Lendvai ined.: 2012).

9185.1: Nyárlőrinc „Bogárzó-erdő” M4 (Kevey \& Urbán ined.: 2020).

9884.1: Kelebia „Nagy-Kéri-erdő” M4 (Kevey \& Lendvai ined.: 2019).

Nyírség:

8299.4: Bátorliget „Fényi-erdő” M4 (Kevey \& Papp ined.: 2020).

\section{Thymus glabrescens Willd.}

\section{Duna-Tisza köze:}

9083.1: Hetényegyháza „Nagy-Nyíri-erdő” M4 (Kevey \& Urbán ined.: 2020).

9083.3: Hetényegyháza „Nagy-Nyíri-erdő” M4 (Kevey \& Urbán ined.: 2020).

9884.1: Kelebia „Nagy-Kéri-erdő” M4 (Kevey \& Lendvai ined.: 2019).

Nyírség:

8299.4: Bátorliget „Fényi-erdő” M4 (Kevey \& Papp ined.: 2020).

8497.3: Debrecen-Haláp „Álló-hegy” M4 (Kevey, Demeter \& Papp ined.: 2019).

8497.4: Vámospércs „Jónás-rész” M4 (Kevey \& Papp ined.: 2019).

\section{Thymus pannonicus All.}

Duna-Tisza köze:

8882.3: Táborfalva „Lőtér” M5 (Kevey \& Lendvai ined.: 2012).

8981.2: Kunpeszér „Peszéri-erdő” M4 (Kevey \& Urbán ined.: 2019).

8984.1: Nagykőrös „Csókás-erdő” M4 (Kevey \& Lendvai ined.: 2012).

Körös-vidék:

9193.1: Bélmegyer „Szolga-erdő” M3 (Kevey ined.: 2002).

\section{Tilia tomentosa Moench}

Tiszántúl:

8391.4: Hortobágy „Ohati-erdő” M3 (Kevey \& Papp ined.: 2017). 
Tragopogon orientalis L.

Duna-Tisza köze:

9884.1: Kelebia „Nagy-Kéri-erdő” M4 (Kevey \& Lendvai ined.: 2019).

\section{Trifolium alpestre $\mathrm{L}$.}

Nyírség:

8497.3: Debrecen-Haláp „Álló-hegy” M4 (Kevey, Demeter \& Papp ined.: 2019).

8497.4: Vámospércs „Jónás-rész” M4 (Kevey \& Papp ined.: 2019).

8597.2: Vámospércs „Bagaméri-erdő” M4 (Kevey \& Papp ined.: 2019).

\section{Trifolium arvense $\mathrm{L}$.}

Nyírség:

8497.4: Vámospércs „Jónás-rész” M4 (Kevey \& Papp ined.: 2019).

\section{Trifolium campestre Schreb.}

Nyírség:

8497.3: Debrecen-Haláp „Álló-hegy” M4 (Kevey \& Papp ined.: 2019).

8497.4: Vámospércs „Jónás-rész” M4 (Kevey \& Papp ined.: 2019).

Trifolium medium L. subsp. sarosiense (Hazsl.) Simonk.

Duna-Tisza köze:

8981.2: Kunpeszér „Peszéri-erdő” M4 (Kevey \& Urbán ined.: 2019).

8984.1: Nagykőrös „Csókás-erdő” M4 (Kevey \& Urbán ined.: 2018).

Nyírség:

8596.2: Debrecen-Bánk „Kalánhegyi-tölgyes” M4 (Kevey \& Papp ined.: 2019).

\section{Trifolium montanum L.}

Duna-Tisza köze:

9082.1: Kunbaracs „Búhegyi-erdő” M4 (Kevey \& Urbán ined.: 2020).

9185.1: Nyárlőrinc „Bogárzó-erdő” M4 (Kevey \& Urbán ined.: 2020).

Nyírség:

8497.4: Vámospércs „Jónás-rész” M4 (Kevey \& Papp ined.: 2019).

8597.2: Vámospércs „Bagaméri-erdő” M4 (Kevey \& Papp ined.: 2019).

Trollius europaeus L.

Mezőföld:

9278.3: Németkér „a Hardi-ér mentén” (Kalotás in KevEY 1990: 85).

Belső-Somogy:

9571.3: Újvárfalva „Bagó-rét” (Novacsek in Kevey 1990: 85).

\section{Valeriana officinalis L.}

Duna-Tisza köze:

8981.2: Kunpeszér „Peszéri-erdő” M4 (Kevey \& Urbán ined.: 2019).

Nyírség:

8497.4: Vámospércs „Jónás-rész” M4 (Kevey \& Papp ined.: 2019).

8596.2: Debrecen-Bánk „Kalánhegyi-tölgyes” M4 (Kevey \& Papp ined.: 2019).

8597.2: Vámospércs „Bagaméri-erdő” M4 (Kevey \& Papp ined.: 2019).

Valerianella dentata (L.) Pollich

Körös-vidék:

8796.3: Hencida „Csere-erdő” M3 (Kevey \& Papp ined.: 2017).

9193.1: Bélmegyer „Szolga-erdő” M3 (Kevey ined.: 2002).

Verbascum chaixii Vill. subsp. austriacum (Schott) Hayek Duna-Tisza köze:

8782.1: Csévharaszt „Pótharaszti-erdő” M4 (Kevey \& Urbán ined.: 2020).

8881.4: Kunpeszér „Rácz-ház” M4 (Kevey \& Urbán ined.: 2020).

9884.1: Kelebia „Nagy-Kéri-erdő” M4 (Kevey \& Lendvai ined.: 2019). 


\section{Verbascum lychnitis L.}

Duna-Tisza köze:

8984.1: Nagykőrös „Csókás-erdő” M4 (Kevey \& Urbán ined.: 2018), „Nagy-erdő” M4 (Kevey \& Lendvai ined.: 2012); Csemő „Szénásteleki-erdő” M4 (Kevey \& Urbán ined.: 2018).

9082.1: Kunbaracs „Búhegyi-erdő” M4 (Kevey \& Urbán ined.: 2020).

9185.1: Nyárlőrinc „Bogárzó-erdő” M4 (Kevey \& Urbán ined.: 2020).

9884.1: Kelebia „Nagy-Kéri-erdő” M4 (Kevey \& Lendvai ined.: 2019).

\section{Verbascum phoeniceum $\mathrm{L}$.}

Jászság:

8586.3: Alattyán „Berki-erdő” M3 (Kevey \& Urbán ined.: 2018).

8686.2: Jászalsószentgyögy „Borsa-erdő” M3 (Kevey \& Urbán ined.: 2017).

\section{Verbascum nigrum L.}

Jászság:

8686.1: Jászalsószentgyögy „Borsa-erdő” M3 (Kevey \& Urbán ined.: 2017).

\section{Veronica anagallis-aquatica $\mathrm{L}$.}

Körös-vidék:

9394.3: Gyula „Kutyahelyi-erdő” M3 (Kevey ined.: 2003).

\section{Veronica arvensis L.}

Jászság:

8686.2: Jászalsószentgyögy „Borsa-erdő” M3 (Kevey \& Urbán ined.: 2017).

Tiszántúl:

8391.4: Hortobágy „Ohat-erdő” M3 (Kevey \& Molnár A. ined.: 2016).

\section{Veronica chamaedrys $\mathrm{L}$.}

Jászság:

8686.1: Jászalsószentgyögy „Borsa-erdő” M3 (Kevey \& Urbán ined.: 2017).

Duna-Tisza köze:

8881.4: Kunpeszér „Rácz-ház” M4 (Kevey \& Urbán ined.: 2020).

9185.1: Nyárlőrinc „Bogárzó-erdő” M4 (Kevey \& Urbán ined.: 2020).

Tiszántúl:

8391.4: Hortobágy „Ohat-erdő” M3 (Kevey \& Molnár A. ined.: 2016).

Nyírség:

8497.3: Debrecen-Haláp „Álló-hegy” M4 (Kevey, Demeter \& Papp ined.: 2019).

8497.4: Vámospércs „Jónás-rész” M4 (Kevey \& Papp ined.: 2019).

8597.2: Vámospércs „Bagaméri-erdő” M4 (Kevey \& Papp ined.: 2019).

\section{Körös-vidék:}

9293.4: Doboz „Papholt-erdő” M3 (Kevey ined.: 2002).

9394.3: Gyula „Gelvács” M3 (Kevey ined.: 2003).

\section{Veronica hederifolia agg.}

Jászság:

8686.1: Jászalsószentgyögy „Borsa-erdő” M3 (Kevey \& Urbán ined.: 2017).

8686.2: Jászalsószentgyögy „Borsa-erdő” M3 (Kevey \& Urbán ined.: 2017).

Nyírség:

8497.3: Debrecen-Haláp „Álló-hegy” M4 (Kevey, Demeter \& Papp ined.: 2019).

8497.4: Vámospércs „Jónás-rész” M4 (Kevey \& Papp ined.: 2019).

8597.2: Vámospércs „Bagaméri-erdő” M4 (Kevey \& Papp ined.: 2019).

Körös-vidék:

9293.4: Doboz „Papholt-erdő” M3 (Kevey ined.: 2002).

9394.3: Gyula „Gelvács” M3 (Kevey ined.: 2003).

\section{Veronica jacquinii Baumg.}

Duna-Tisza köze:

8981.2: Kunpeszér „Peszéri-erdő” M4 (Kevey \& Urbán ined.: 2019). 
Veronica officinalis $\mathrm{L}$.

Körös-vidék:

8796.3: Hencida „Csere-erdő” M3 (Kevey \& Papp ined.: 2017).

Nyírség:

8497.3: Debrecen-Haláp „Álló-hegy” M4 (Kevey, Demeter \& Papp ined.: 2019).

8497.4: Vámospércs „Jónás-rész” M4 (Kevey \& Papp ined.: 2019).

8596.2: Debrecen-Bánk „Kalánhegyi-tölgyes” M4 (Kevey \& Papp ined.: 2019).

8597.2: Vámospércs „Bagaméri-erdő” M4 (Kevey \& Papp ined.: 2019).

Veronica praecox All.

Duna-Tisza köze:

8984.1: Csemő „Szénásteleki-erdő” M4 (Kevey \& Lendvai ined.: 2012).

Körös-vidék:

9394.3: Gyula „Kutyahelyi-erdő” M3 (Kevey ined.: 2003).

\section{Veronica serpyllifolia L.}

Körös-vidék:

8796.3: Hencida „Csere-erdő” M3 (Kevey \& Papp ined.: 2017).

\section{Veronica teucrium $\mathrm{L}$.}

Jászság:

8686.2: Jászalsószentgyögy „Borsa-erdő” M3 (Kevey \& Urbán ined.: 2017).

Duna-Tisza köze:

8984.1: Nagykőrös „Csókás-erdő” M4 (Kevey \& Lendvai ined.: 2012).

Veronica triphyllos $\mathrm{L}$.

Duna-Tisza köze:

8984.1: Nagykőrös „Nagy-erdő” M4 (Kevey \& Lendvai ined.: 2012).

\section{Viburnum lantana $\mathrm{L}$.}

Duna-Tisza köze:

9082.1: Kunbaracs „Búhegyi-erdő” L5 (Kevey \& Urbán ined.: 2020).

9083.1: Hetényegyháza „Nagy-Nyíri-erdő” L5 (Kevey \& Urbán ined.: 2020).

Csepel-sziget:

8779.3: Ráckeve „Silling-erdő” J6 (KEVEY 1990: 87).

8779.4: Szigetújfalu „Újfalusi-erdő” J6 (Kevey ined.: 1987).

8780.1: Szigethalom „Tököli-erdő” J6 (Kevey ined.: 1993).

8879.1: Ráckeve „Silling-erdő” J6 (Kevey 1990: 87).

8979.1: Makád „Rókás” L5 (Kevey ined.: 1989).

\section{Viburnum opulus L.}

Nyírség:

8497.4: Vámospércs „Jónás-rész” J6 (Kevey \& Papp ined.: 2019).

\section{Vicia angustifolia L.}

Duna-Tisza köze:

8882.3: Táborfalva „Lőtér” M5 (Kevey \& Lendvai ined.: 2012).

\section{Vicia cracca L.}

Nyírség:

8497.3: Debrecen-Haláp „Álló-hegy” M4 (Kevey \& Papp ined.: 2019).

8597.2: Vámospércs „Bagaméri-erdő” M4 (Kevey \& Papp ined.: 2019).

Vicia grandiflora Scop.

Nyírség:

8597.2: Vámospércs „Bagaméri-erdő” M4 (Kevey \& Papp ined.: 2019). 
Vicia hirsuta (L.) Gray

Jászság:

8586.3: Alattyán „Berki-erdő” M3 (Kevey \& Urbán ined.: 2018).

Duna-Tisza köze:

8882.3: Táborfalva „Lőtér” M5 (Kevey \& Lendvai ined.: 2012).

Nyírség:

8497.3: Debrecen-Haláp „Álló-hegy” M4 (Kevey, Demeter \& Papp ined.: 2019).

8596.2: Debrecen-Bánk „Kalánhegyi-tölgyes” M4 (Kevey \& Papp ined.: 2019).

8597.2: Vámospércs „Bagaméri-erdő” M4 (Kevey \& Papp ined.: 2019).

\section{Vicia lathyroides $\mathrm{L}$.}

Nyírség:

8497.3: Debrecen-Haláp „Álló-hegy” M4 (Kevey, Demeter \& Papp ined.: 2019).

Vicia pannonica Crantz subsp. pannonica

Nyírség:

8596.2: Debrecen-Bánk „Kalánhegyi-tölgyes” M4 (Kevey \& Papp ined.: 2019).

\section{Vicia sepium L.}

Tiszántúl:

8292.4: Újszentmargita „Tilos-erdő” M3 (Kevey \& Molnár A. ined.: 2017).

8391.4: Hortobágy „Ohat-erdô” M3 (Kevey \& Molnár A. ined.: 2016).

Nyírség:

8497.3: Debrecen-Haláp „Álló-hegy” M4 (Kevey \& Papp ined.: 2019).

Vicia tenuifolia Roth

Duna-Tisza köze:

9185.1: Nyárlőrinc „Bogárzó-erdő” M4 (Kevey \& Urbán ined.: 2020).

Nyírség:

8497.4: Vámospércs „Jónás-rész” M4 (Kevey \& Papp ined.: 2019).

Vicia tetrasperma (L.) Schreb.

Jászság:

8586.3: Alattyán „Berki-erdő” M3 (Kevey \& Urbán ined.: 2018).

Körös-vidék:

9293.4: Doboz „Papholt-erdő” M3 (Kevey ined.: 2002).

9394.3: Gyula „Gelvács” M3 (Kevey ined.: 2003).

Vicia villosa Roth

Nyírség:

8299.4: Bátorliget „Fényi-erdő” M4 (Kevey \& Papp ined.: 2020).

Vinca herbacea Waldst. et Kit.

Duna-Tisza köze:

8984.1: Nagykőrös „Nagy-erdő” M4 (Kevey \& Urbán ined.: 2018).

9083.1: Hetényegyháza „Nagy-Nyíri-erdő” M4 (Kevey \& Urbán ined.: 2020).

9083.3: Hetényegyháza „Nagy-Nyíri-erdő” M4 (Kevey \& Urbán ined.: 2020).

\section{Vinca minor L.}

Mezőföld:

8678.4: Martonvásár „Kastély-park” K1a, J6 (KeveY 1983: 21).

9378.2: Paks-Gyapa „Park-erdő” J6 (Kevey 1983: 21).

Csepel-sziget:

8779.4: Szigetújfalu „Újfalusi-erdő” J6 (Vajda in KEVEY 1983: 21).

Mohácsi-sziget:

0078.3: Kölked „Felső-Béda” J6, K1a (Borhidi in KeveY et al. 1992: 17).

0079.3: Hercegszántó „Szarvastanya” J6, J1a (KevEY 1995: 47). 


\section{Vincetoxicum hirundinaria Medik.}

\section{Duna-Tisza köze:}

9083.1: Hetényegyháza „Nagy-Nyíri-erdő” M4 (Kevey \& Urbán ined.: 2020).

9083.3: Hetényegyháza „Nagy-Nyíri-erdő” M4 (Kevey \& Urbán ined.: 2020).

\section{Tiszántúl:}

8391.4: Hortobágy „Ohat-erdo”” M3 (Kevey \& Molnár A. ined.: 2016).

Nyírség:

8497.3: Debrecen-Haláp „Álló-hegy” M4 (Kevey, Demeter \& Papp ined.: 2019).

8596.2: Debrecen-Bánk „Kalánhegyi-tölgyes” M4 (Kevey \& Papp ined.: 2019).

Körös-vidék:

9293.4: Doboz „Papholt-erdő” M3 (Kevey ined.: 2002).

\section{Viola alba Besser}

\section{Mezőföld:}

8976.4: Soponya-Nagyláng „Kastélypark” J6, K1a (KEvEY 1983: 21).

9478.3: Tengelic „Zöld-erdő” L5 (KEVEY 1990: 89).

Mohácsi-sziget:

9979.3: Dunafalva „Tiser-erdő” J6 (Kevey 1990: 89).

0078.4: Homorud „Szállás-erdő” J6, K1a (KEVEY 1990: 89).

\section{Viola canina L.}

Duna-Tisza köze:

8984.1: Nagykőrös „Nagy-erdő” M4 (Kevey \& Urbán ined.: 2018).

Nyírség:

8497.3: Debrecen-Haláp „Álló-hegy” M4 (Kevey, Demeter \& Papp ined.: 2019).

\section{Viola hirta L.}

Jászság:

8586.3: Alattyán „Berki-erdő” M3 (Kevey \& Urbán ined.: 2018).

Duna-Tisza köze:

9082.1: Kunbaracs „Búhegyi-erdő” M4 (Kevey \& Urbán ined.: 2020).

9083.1: Hetényegyháza „Nagy-Nyíri-erdő” M4 (Kevey \& Urbán ined.: 2020).

9185.1: Nyárlőrinc „Bogárzó-erdő” M4 (Kevey \& Urbán ined.: 2020).

Tiszántúl:

8391.4: Hortobágy „Ohat-erdő” M3 (Kevey \& Molnár A. ined.: 2016).

Nyírség:

8497.3: Debrecen-Haláp „Álló-hegy” M4 (Kevey, Demeter \& Papp ined.: 2019).

8597.2: Vámospércs „Bagaméri-erdő” M4 (Kevey \& Papp ined.: 2019).

\section{Körös-vidék:}

9193.1: Bélmegyer „Szolga-erdo”” M3 (Kevey ined.: 2002).

9293.4: Doboz „Papholt-erdő” M3 (Kevey ined.: 2002).

9394.3: Gyula „Gelvács” M3 (Kevey ined.: 2003).

Viola kitaibeliana Roem. et Schult.

Duna-Tisza köze:

8984.1: Nagykőrös „Csókás-erdő” M4 (Kevey \& Lendvai ined.: 2012), „Nagy-erdő” M4 (Kevey \& Lendvai ined.: 2012).

9083.3: Hetényegyháza „Nagy-Nyíri-erdő” M4 (Kevey \& Urbán ined.: 2020).

\section{Viola reichenbachiana Jord.}

Duna-Tisza köze:

9083.1: Hetényegyháza „Nagy-Nyíri-erdő” J6 (Kevey \& Urbán ined.: 2020).

\section{Csepel-sziget:}

8879.3: Lórév „Makádi-erdő” J6 (KeVEY 1993: 56).

8979.1: Makád „Rókás” J6 (KeveY 1993: 56).

Mezőföld:

8678.4: Martonvásár „Kastély-park” J6 (KEVEY 1987: 38).

8976.4: Soponya-Nagyláng „Kastélypark” J6, K1a (KeveY 1993: 56).

9075.3: Enying „Fenyves-dülő = Kustyán-erdő” J6 (Horvát \& Kevey in KEVEY 1993: 56). 
9277.4: Vajta „Nagy-erdő” K1a (KeVEY 1993: 56).

9378.1: Bikács-Kistápé „Akalacsi-erdő” K1a (KevEY 1993: 56); Vajta „Nagy-erdő” K1a (KevEY 1993: 56).

9378.3: Nagydorog „Banai-erdő” K1a (KEVEY 1993: 56).

9478.1: Tengelic „Felsőtengelici-erdő” K1a (KEVEY 1993: 56).

Viola riviniana Rchb.

Tiszántúl:

8292.4: Újszentmargita „Tilos-erdő” M3 (Kevey \& Molnár A. ined.: 2017).

Viola rupestris F.W. Schmidt

Duna-Tisza köze:

8882.3: Táborfalva „Lőtér” M5 (Kevey \& Lendvai ined.: 2012).

8981.2: Kunpeszér „Peszéri-erdő” M4 (Kevey \& Urbán ined.: 2019).

8984.1: Nagykőrös „Nagy-erdő” M4 (Kevey \& Lendvai ined.: 2012).

9082.1: Kunbaracs „Búhegyi-erdő” M4 (Kevey \& Urbán ined.: 2020).

Nyírség:

8497.3: Debrecen-Haláp „Álló-hegy” M4 (Kevey, Demeter \& Papp ined.: 2019).

8497.4: Vámospércs „Jónás-rész” M4 (Kevey \& Papp ined.: 2019).

8597.2: Vámospércs „Bagaméri-erdő” M4 (Kevey \& Papp ined.: 2019).

Viola suavis $\mathrm{M}$. Bieb.

Jászság:

8586.3: Alattyán „Berki-erdő” M3 (Kevey \& Urbán ined.: 2018).

8686.1: Jászalsószentgyögy „Borsa-erdő” M3 (Kevey \& Urbán ined.: 2017).

Duna-Tisza köze:

8782.1: Csévharaszt „Pótharaszti-erdő” M4 (Kevey \& Urbán ined.: 2020).

8881.4: Kunpeszér „Rácz-ház” M4 (Kevey \& Urbán ined.: 2020).

8882.3: Táborfalva „Lőtér" M5 (Kevey \& Lendvai ined.: 2012).

8981.2: Kunpeszér „Peszéri-erdő” M4 (Kevey \& Urbán ined.: 2019).

8984.1: Nagykőrös „Nagy-erdő” M4 (Kevey \& Urbán ined.: 2018).

9082.1: Kunbaracs „Búhegyi-erdő” M4 (Kevey \& Urbán ined.: 2020).

9083.1: Hetényegyháza „Nagy-Nyíri-erdő” M4 (Kevey \& Urbán ined.: 2020).

9083.3: Hetényegyháza „Nagy-Nyíri-erdő” M4 (Kevey \& Urbán ined.: 2020).

9185.1: Nyárlőrinc „Bogárzó-erdő” M4 (Kevey \& Urbán ined.: 2020).

Tiszántúl:

8391.4: Hortobágy „Ohat-erdő” M3 (Kevey \& Molnár A. ined.: 2016).

Körös-vidék:

8796.3: Hencida „Csere-erdő” M3 (Kevey \& Papp ined.: 2017).

9293.4: Doboz „Papholt-erdő” M3 (Kevey ined.: 2002).

9394.3: Gyula „Gelvács” M3 (Kevey ined.: 2003).

\section{Viscum album L.}

Mezőföld:

9176.2: Dég „Kastély-park” J6 (Horvát \& Kevey in KevEY 1984: 52).

Vitis sylvestris C.C. Gmel.

Duna-Tisza köze:

9083.1: Hetényegyháza „Nagynyíri-erdő” L5 (Kevey \& Urbán ined.: 2020).

Mezőföld:

9378.1: Bikács-Kistápé „Akalacsi-erdő” K1a, L5 (Kevey 1983: 20).

Csepel-sziget:

8779.2: Szigetújfalu „Újfalusi-erdő” J6 (Kevey 1990: 86).

Monocotyledonopsida

Agropyron cristatum (L.) Gaertn.

Duna-Tisza köze:

9083.1: Hetényegyháza „Nagy-Nyíri-erdő” M4 (Kevey \& Urbán ined.: 2020). 
Agrostis capillaris L.

Nyírség:

8497.3: Debrecen-Haláp „Álló-hegy” M4 (Kevey, Demeter \& Papp ined.: 2019).

\section{Allium oleraceum L.}

Jászság:

8686.2: Jászalsószentgyögy „Borsa-erdő” M3 (Kevey \& Urbán ined.: 2017).

Nyírség:

8597.2: Vámospércs „Bagaméri-erdő” M4 (Kevey \& Papp ined.: 2019).

Körös-vidék:

9394.3: Gyula „Kutyahelyi-erdő” M3 (Kevey ined.: 2003).

\section{Allium paniculatum $\mathrm{L}$.}

Duna-Tisza köze:

8984.1: Nagykőrös „Csókás-erdő” M4 (Kevey \& Urbán ined.: 2019).

9185.1: Nyárlőrinc „Bogárzó-erdő” M4 (Kevey \& Urbán ined.: 2020).

\section{Allium sphaerocephalon L.}

Duna-Tisza köze:

9083.3: Hetényegyháza „Nagy-Nyíri-erdő” M4 (Kevey \& Urbán ined.: 2020).

Tiszántúl:

8292.4: Újszentmargita „Tilos-erdő” M3 (Kevey \& Molnár A. ined.: 2017).

8391.4: Hortobágy „Ohat-erdő” M3 (Kevey \& Molnár A. ined.: 2016).

\section{Allium vineale $\mathrm{L}$.}

Jászság:

8586.3: Alattyán „Berki-erdo”” M3 (Kevey \& Urbán ined.: 2018).

8686.1: Jászalsószentgyögy „Borsa-erdő” M3 (Kevey \& Urbán ined.: 2017).

8686.2: Jászalsószentgyögy „Borsa-erdő” M3 (Kevey \& Urbán ined.: 2017).

Tiszántúl:

8292.4: Újszentmargita „Tilos-erdő” M3 (Kevey \& Molnár A. ined.: 2017).

Körös-vidék:

8796.3: Hencida „Csere-erdő” M3 (Kevey \& Papp ined.: 2017).

9193.1: Bélmegyer „Szolga-erdo” M3 (Kevey ined.: 2002).

9293.4: Doboz „Papholt-erdő” M3 (Kevey ined.: 2002).

9394.3: Gyula „Gelvács” M3 (Kevey ined.: 2003).

Nyírség:

8299.4: Bátorliget „Fényi-erdő” M4 (Kevey \& Papp ined.: 2020).

8596.2: Debrecen-Bánk „Kalánhegyi-tölgyes” M4 (Kevey \& Papp ined.: 2019).

\section{Anthericum ramosum L.}

Duna-Tisza köze:

8981.2: Kunpeszér „Peszéri-erdő” M4 (Kevey \& Urbán ined.: 2019).

9083.3: Hetényegyháza „Nagy-Nyíri-erdő” M4 (Kevey \& Urbán ined.: 2020).

Nyírség:

8299.4: Bátorliget „Fényi-erdo” M4 (Kevey \& Papp ined.: 2020).

\section{Anthoxanthum odoratum L.}

Nyírség:

8497.3: Debrecen-Haláp „Álló-hegy” M4 (Kevey, Demeter \& Papp ined.: 2019).

8497.4: Vámospércs „Jónás-rész” M4 (Kevey \& Papp ined.: 2019).

8597.2: Vámospércs „Bagaméri-erdő” M4 (Kevey \& Papp ined.: 2019).

\section{Arum orientale M. Bieb.}

Mezőföld:

8678.4: Martonvásár „Kastély-park” J6, K1a (KEVEY 1987: 36).

9176.1: Dég „a Kastély-park Ôztelek felőli sarkán” J6 (MAJER 1979: 10; KEVEY 1984: 53). 
Asparagus officinalis L.

Tiszántúl:

8391.4: Hortobágy „Ohat-erdő” M3 (Kevey \& Molnár A. ined.: 2016).

Nyírség:

8497.3: Debrecen-Haláp „Álló-hegy” M4 (Kevey, Demeter \& Papp ined.: 2019).

8497.4: Vámospércs „Jónás-rész” M4 (Kevey \& Papp ined.: 2019).

8597.2: Vámospércs „Bagaméri-erdő” M4 (Kevey \& Papp ined.: 2019).

Körös-vidék:

9293.4: Doboz „Papholt-erdő” M3 (Kevey ined.: 2002).

Brachypodium pinnatum (L.) P. Beauv.

Duna-Tisza köze:

8981.2: Kunpeszér „Peszéri-erdo” M4 (Kevey \& Urbán ined.: 2019).

9082.1: Kunbaracs „Búhegyi-erdő” M4 (Kevey \& Urbán ined.: 2020).

9185.1: Nyárlőrinc „Bogárzó-erdő” M4 (Kevey \& Urbán ined.: 2020).

Nyírség:

8497.3: Debrecen-Haláp „Álló-hegy” M4 (Kevey, Demeter \& Papp ined.: 2019).

8596.2: Debrecen-Bánk „Kalánhegyi-tölgyes” M4 (Kevey \& Papp ined.: 2019).

8597.2: Vámospércs „Bagaméri-erdő” M4 (Kevey \& Papp ined.: 2019).

Brachypodium sylvaticum (Huds.) P. Beauv.

Duna-Tisza köze:

9083.3: Hetényegyháza „Nagy-Nyíri-erdő” M4 (Kevey \& Urbán ined.: 2020).

Tiszántúl:

8391.4: Hortobágy „Ohat-erdo”” M3 (Kevey \& Molnár A. ined.: 2016).

Körös-vidék:

8796.3: Hencida „Csere-erdő” M3 (Kevey \& Papp ined.: 2017).

Nyírség:

8497.3: Debrecen-Haláp „Álló-hegy” M4 (Kevey, Demeter \& Papp ined.: 2019).

\section{Briza media L.}

Nyírség:

8497.3: Debrecen-Haláp „Álló-hegy” M4 (Kevey, Demeter \& Papp ined.: 2019).

8497.4: Vámospércs „Jónás-rész” M4 (Kevey \& Papp ined.: 2019).

\section{Bromus commutatus Schrad.}

Körös-vidék:

9193.1: Bélmegyer „Szolga-erdo”” M3 (Kevey ined.: 2002).

9293.4: Doboz „Papholt-erdő” M3 (Kevey ined.: 2002).

9394.3: Gyula „Kutyahelyi-erdő” M3 (Kevey ined.: 2003).

Bromus inermis Leiss.

Duna-Tisza köze:

8984.1: Nagykőrös „Csókás-erdő” M4 (Kevey \& Urbán ined.: 2018).

Tiszántúl:

8391.4: Hortobágy „Ohat-erdo”" M3 (Kevey \& Molnár A. ined.: 2016).

Nyírség:

8497.4: Vámospércs „Jónás-rész” M4 (Kevey \& Papp ined.: 2019).

8597.2: Vámospércs „Bagaméri-erdő” M4 (Kevey \& Papp ined.: 2019).

Bromus ramosus Huds.

Tiszántúl:

8391.4: Hortobágy „Ohat-erdo” M3 (Kevey \& Molnár A. ined.: 2016).

\section{Bulbocodium vernum $\mathrm{L}$.}

Duna-Tisza köze:

9884.1: Kelebia „Nagy-Kéri-erdő” M4 (Krnács ined.: 2019).

Nyírség:

8596.2: Debrecen-Bánk „Kalánhegyi-tölgyes” olim M4 (Kevey \& Papp ined.: 2019). 


\section{Carex acuta L.}

Nyírség:

8597.2: Vámospércs „Bagaméri-erdő” M4 (Kevey \& Papp ined.: 2019).

\section{Carex brizoides $\mathrm{L}$.}

Jászság:

8586.3: Alattyán „Berki-erdő” M3 (Kevey \& Urbán ined.: 2018).

\section{Tiszántúl:}

8391.4: Hortobágy „Ohat-erdő” M3 (Kevey \& Molnár A. ined.: 2016).

Körös-vidék:

8796.3: Hencida „Csere-erdő” M3 (Kevey \& Papp ined.: 2017).

Nyírség:

8597.2: Vámospércs „Bagaméri-erdő” M4 (Kevey \& Papp ined.: 2019).

\section{Carex caryophyllea Latourr.}

Duna-Tisza köze:

8981.2: Kunpeszér „Peszéri-erdő” M4 (Kevey \& Urbán ined.: 2019).

9083.1: Hetényegyháza „Nagy-Nyíri-erdő” M4 (Kevey \& Urbán ined.: 2020).

9185.1: Nyárlőrinc „Bogárzó-erdő” M4 (Kevey \& Urbán ined.: 2020).

9884.1: Kelebia „Nagy-Kéri-erdő” M4 (Kevey \& Lendvai ined.: 2019).

\section{Carex distans L.}

\section{Körös-vidék:}

9394.3: Gyula „Kutyahelyi-erdő” M3 (Kevey ined.: 2003).

\section{Carex elata All.}

Jászság:

8586.3: Alattyán „Berki-erdő” M3 (Kevey \& Urbán ined.: 2018).

8686.1: Jászalsószentgyögy „Borsa-erdő” M3 (Kevey \& Urbán ined.: 2017).

8686.2: Jászalsószentgyögy „Borsa-erdő” M3 (Kevey \& Urbán ined.: 2017).

\section{Carex flacca Schreb.}

Duna-Tisza köze:

8981.2: Kunpeszér „Peszéri-erdő” M4 (Kevey \& Urbán ined.: 2019).

9185.1: Nyárlőrinc „Bogárzó-erdő” M4 (Kevey \& Urbán ined.: 2020).

Nyírség:

8497.4: Vámospércs „Jónás-rész” M4 (Kevey \& Papp ined.: 2019).

\section{Carex humilis Leyss.}

Duna-Tisza köze:

9185.1: Nyárlőrinc „Bogárzó-erdő” M4 (Kevey \& Urbán ined.: 2020).

\section{Carex liparicarpos Gaudin}

Duna-Tisza köze:

8984.1: Csemő „Szénásteleki-erdő” M4 (Kevey \& Urbán ined.: 2018).

\section{Carex michelii Host}

\section{Duna-Tisza köze:}

8782.1: Csévharaszt „Pótharaszti-erdő” M4 (Kevey \& Urbán ined.: 2020). 8981.2: Kunpeszér „Peszéri-erdő” M4 (Kevey \& Urbán ined.: 2019).

9083.1: Hetényegyháza „Nagy-Nyíri-erdő” M4 (Kevey \& Urbán ined.: 2020).

9185.1: Nyárlőrinc „Bogárzó-erdő” M4 (Kevey \& Urbán ined.: 2020).

Nyírség:

8497.3: Debrecen-Haláp „Álló-hegy” M4 (Kevey \& Papp ined.: 2019).

Carex otrubae Podp.

Tiszántúl:

8292.4: Újszentmargita „Tilos-erdő” M3 (Kevey \& Molnár A. ined.: 2017). 
Carex pilosa Scop.

Mezőföld:

8976.4: Soponya-Nagyláng „Kastélypark” K1a (KEVEY 1983: 22).

Carex praecox Schreb.

Jászság:

8686.1: Jászalsószentgyögy „Borsa-erdő” M3 (Kevey \& Urbán ined.: 2017).

8686.2: Jászalsószentgyögy „Borsa-erdő” M3 (Kevey \& Urbán ined.: 2017).

Duna-Tisza köze:

9083.1: Hetényegyháza „Nagy-Nyíri-erdő” M4 (Kevey \& Urbán ined.: 2020).

Nyírség:

8497.3: Debrecen-Haláp „Álló-hegy” M4 (Kevey, Demeter \& Papp ined.: 2019).

8497.4: Vámospércs „Jónás-rész” M4 (Kevey \& Papp ined.: 2019).

8597.2: Vámospércs „Bagaméri-erdő” M4 (Kevey \& Papp ined.: 2019).

Körös-vidék:

9293.4: Doboz „Papholt-erdő” M3 (Kevey ined.: 2002).

\section{Carex remota L.}

\section{Csepel-sziget:}

8779.3: Ercsi „Sziget-erdő” J6 (Kevey ined.: 2012).

8779.3: Szigetújfalu „Újfalusi-erdő” J4, J6 (Kevey ined.: 1987).

8879.1: Ráckeve „Besnyő” J4, J6 (Kevey ined.: 1987).

8979.1: Makád „Rókás” J6 (Kevey ined.: 1989).

8979.4: Makád „Sasréti-erdo”” J6 (Kevey ined.: 1990); Rácalmás „Kis-sziget” J4 (Kevey ined.: 1998).

Carex spicata Huds.

Nyírség:

8497.4: Vámospércs „Jónás-rész” M4 (Kevey \& Papp ined.: 2019).

Körös-vidék:

9193.1: Bélmegyer „Szolga-erdo” M3 (Kevey ined.: 2002).

Carex supina Wahlenb.

Nyírség:

8497.3: Debrecen-Haláp „Álló-hegy” M4 (Kevey, Demeter \& Papp ined.: 2019).

8597.2: Vámospércs „Bagaméri-erdő” M4 (Kevey \& Papp ined.: 2019).

\section{Carex tomentosa L.}

Nyírség:

8497.3: Debrecen-Haláp „Álló-hegy” M4 (Kevey \& Papp ined.: 2019).

8497.4: Vámospércs „Jónás-rész” M4 (Kevey \& Papp ined.: 2019).

8596.2: Debrecen-Bánk „Kalánhegyi-tölgyes” M4 (Kevey \& Papp ined.: 2019).

Körös-vidék:

9394.3: Gyula „Kutyahelyi-erdő” M3 (Kevey ined.: 2003).

\section{Carex vulpina $\mathrm{L}$.}

Tiszántúl:

8391.4: Hortobágy „Ohat-erdo”” M3 (Kevey \& Molnár A. ined.: 2016).

Catabrosa aquatica (L.) P. Beauv.

Szekszárdi-dombság:

9777.2: Szálka „Rác-erdő” J5 (KEvEY 1993: 58).

Cephalanthera longifolia (L.) Fritsch

Zselic:

9773.4: Szágy „Besenczi-erdő K2 (Kevey ined.: 2020). 
Chrysopogon gryllus (L.) Trin.

Duna-Tisza köze:

9082.1: Kunbaracs „Búhegyi-erdő” M4 (Kevey \& Urbán ined.: 2020).

9185.1: Nyárlőrinc „Bogárzó-erdő” M4 (Kevey \& Urbán ined.: 2020).

Nyírség:

8497.4: Vámospércs „Jónás-rész” M4 (Kevey \& Papp ined.: 2019).

Colchicum arenarium Waldst. et Kit.

Duna-Tisza köze:

9083.1: Hetényegyháza „Nagy-Nyíri-erdő” M4 (Kevey \& Urbán ined.: 2020).

9083.3: Hetényegyháza „Nagy-Nyíri-erdő” M4 (Kevey \& Urbán ined.: 2020).

\section{Colchicum autumnale $\mathrm{L}$.}

Duna-Tisza köze:

8981.2: Kunpeszér „Peszéri-erdő” M4 (Kevey \& Urbán ined.: 2019).

8984.1: Nagykőrös „Nagy-erdő” M4 (Kevey, Lendvai \& Urbán ined.: 2011).

\section{Convallaria majalis $\mathrm{L}$.}

Duna-Tisza köze:

9082.1: Kunbaracs „Búhegyi-erdő” K1a, L5 (Kevey, Lendvai \& Urbán ined.: 2011).

9185.1: Nyárlőrinc „Bogárzó-erdő” L5 (Kevey \& Urbán ined.: 2020).

\section{Elymus caninus L.}

Duna-Tisza köze:

9185.1: Nyárlőrinc „Bogárzó-erdő” M4 (Kevey \& Urbán ined.: 2020).

Jászság:

8686.2: Jászalsószentgyögy „Borsa-erdő” M3 (Kevey \& Urbán ined.: 2017).

Nyírség:

8497.3: Debrecen-Haláp „Álló-hegy” M4 (Kevey, Demeter \& Papp ined.: 2019).

8596.2: Debrecen-Bánk „Kalánhegyi-tölgyes” M4 (Kevey \& Papp ined.: 2019).

Elymus hispidus (Opiz) Melderis

Nyírség:

8299.4: Bátorliget „Fényi-erdő" M4 (Kevey \& Papp ined.: 2020).

8596.2: Debrecen-Bánk „Kalánhegyi-tölgyes” M4 (Kevey \& Papp ined.: 2019).

Epipactis atrorubens Hoffm. ex Besser

Duna-Tisza köze:

8882.3: Táborfalva „Lőtér” M5 (Kevey \& Lendvai ined.: 2012).

Epipactis microphylla (Ehrh.) Sw.

Mohácsi-sziget:

9979.3: Dunafalva „Tiser-erdő” J6 (KEVEY 1990: 92).

Epipactis tallosii A. Molnár et Robatsch

Nyírség:

8497.3: Debrecen-Haláp „Álló-hegy” M4 (Kevey \& Papp ined.: 2019).

\section{Festuca heterophylla Lam.}

Nyírség:

8497.3: Debrecen-Haláp „Álló-hegy” M4 (Kevey, Demeter \& Papp ined.: 2019).

\section{Festuca rubra L.}

Körös-vidék:

9193.1: Bélmegyer „Szolga-erdő” M3 (Kevey ined.: 2002).

9394.3: Gyula „Kutyahelyi-erdő” M3 (Kevey ined.: 2003). 
Festuca rupicola Heuff.

Nyírség:

8497.3: Debrecen-Haláp „Álló-hegy” M4 (Kevey, Demeter \& Papp ined.: 2019).

8497.4: Vámospércs „Jónás-rész” M4 (Kevey \& Papp ined.: 2019).

8597.2: Vámospércs „Bagaméri-erdő” M4 (Kevey \& Papp ined.: 2019).

Festuca vaginata Waldst. et Kit.

Duna-Tisza köze:

9083.3: Hetényegyháza „Nagy-Nyíri-erdő” M4 (Kevey \& Urbán ined.: 2020).

Festuca valesiaca Schleich. ex Gaudin

Nyírség:

8497.3: Debrecen-Haláp „Álló-hegy” M4 (Kevey, Demeter \& Papp ined.: 2019). 8597.2: Vámospércs „Bagaméri-erdő” M4 (Kevey \& Papp ined.: 2019).

Körös-vidék:

9193.1: Bélmegyer „Szolga-erdo”” M3 (Kevey ined.: 2002).

Gagea pratensis (Pers.) Dumort.

Duna-Tisza köze:

9884.1: Kelebia „Nagy-Kéri-erdő” M4 (Kevey \& Lendvai ined.: 2019).

Gagea pusilla (F.W. Schmidt) Schult et Schult f.

Duna-Tisza köze:

8882.3: Táborfalva „Lőtér” M5 (Kevey \& Lendvai ined.: 2012).

Helictotrichon pubescens (Huds.) Pilg.

Duna-Tisza köze:

9082.1: Kunbaracs „Búhegyi-erdő” M4 (Kevey \& Urbán ined.: 2020).

9185.1: Nyárlőrinc „Bogárzó-erdő” M4 (Kevey \& Urbán ined.: 2020).

Nyírség:

8497.3: Debrecen-Haláp „Álló-hegy” M4 (Kevey, Demeter \& Papp ined.: 2019). 8597.2: Vámospércs „Bagaméri-erdő” M4 (Kevey \& Papp ined.: 2019).

\section{Holcus lanatus L.}

Nyírség:

8497.4: Vámospércs „Jónás-rész” M4 (Kevey \& Papp ined.: 2019).

Hordelymus europaeus (L.) Less. ex Harz

Dráva-sík:

0072.2: Bürüs „Sikota” K1a (Kevey 1981: 181).

Szekszárdi-dombság:

9777.2: Szálka „Szálkai-völgy” K2 (KEvEY 1990: 93).

Belső-Somogy:

9570.2: Mesztegnyő „Búsvár” K1a (KevEY 1993: 58).

9770.2: Nagykorpád „Mórici-erdő” K1a (Kevey ined.: 2017).

Iris aphylla L. subsp. hungarica (Waldst. et Kit.) Hegi

Nyírség:

8299.4: Bátorliget „Fényi-erdő” M4 (Papp ined.: 2020).

8497.4: Vámospércs „Jónás-rész” M4 (Papp ined.: 2019).

8597.2: Vámospércs „Bagaméri-erdő” M4 (Papp ined.: 2019).

Iris arenaria Waldst. et Kit.

Duna-Tisza köze:

8981.2: Kunpeszér „Peszéri-erdő” M4 (Kevey \& Urbán ined.: 2019).

9083.3: Hetényegyháza „Nagy-Nyíri-erdő” M4 (Kevey \& Urbán ined.: 2020).

Nyírség:

8497.3: Debrecen-Haláp „Álló-hegy” M4 (Kevey \& Papp ined.: 2019).

8596.2: Debrecen-Bánk „Kalánhegyi-tölgyes” M4 (Kevey \& Papp ined.: 2019). 
Iris sibirica L.

Mezőföld:

9277.2: Cece „Kákás-tó” (Lendvai in KEvEY 1995: 49), „Téglaégető” (Lendvai in KEvEY 1995: 49).

9378.1: Bikács-Kistápé „Akalacsi-erdő” D2 (KEVEY 1990: 91).

9378.2: Németkér „Látó-hegy” D2 (Kalotás in KEVEY 1995: 49).

9478.1: Tengelic „Éri-patak: a két kastély között” (Zörényi in KEVEY 1995: 49).

Sárköz:

9878.2: Báta „Gyűrűs-alj” D2 (Tóth I. in KEvEY 1995: 49).

Iris spuria L.

Körös-vidék:

8796.3: Hencida „Csere-erdő” M3 (Kevey \& Papp ined.: 2017).

\section{Iris variegata $\mathrm{L}$.}

Duna-Tisza köze:

9082.1: Kunbaracs „Búhegyi-erdő” M4 (Kevey \& Urbán ined.: 2020).

Juncus compressus Jacq.

Körös-vidék:

9394.3: Gyula „Kutyahelyi-erdő” M3 (Kevey ined.: 2003).

Juncus effusus L.

Körös-vidék:

8796.3: Hencida „Csere-erdő” M3 (Kevey \& Papp ined.: 2017).

Nyírség:

8596.2: Debrecen-Bánk „Kalánhegyi-tölgyes” M4 (Kevey \& Papp ined.: 2019).

Juncus gerardii Loisel.

Körös-vidék:

9193.1: Bélmegyer „Szolga-erdo”” M3 (Kevey ined.: 2002).

\section{Juncus conglomeratus L.}

Tiszántúl:

8292.4: Újszentmargita „Tilos-erdő” M3 (Kevey \& Molnár A. ined.: 2017).

Körös-vidék:

8796.3: Hencida „Csere-erdő” M3 (Kevey \& Papp ined.: 2017).

\section{Lilium martagon L.}

Mezőföld:

8976.4: Soponya-Nagyláng „Kastély-park” J6, K1a (KEvEY 1985: 157).

9176.2: Dég „Kastély-park” J6, K1a (KEVEY 1981: 181).

\section{Luzula campestris (L.) DC.}

Tiszántúl:

8292.4: Újszentmargita „Tilos-erdő” M3 (Kevey \& Molnár A. ined.: 2017).

Körös-vidék:

8796.3: Hencida „Csere-erdő” M3 (Kevey \& Papp ined.: 2017).

Nyírség:

8497.3: Debrecen-Haláp „Álló-hegy” M4 (Kevey, Demeter \& Papp ined.: 2019).

8597.2: Vámospércs „Bagaméri-erdő” M4 (Kevey \& Papp ined.: 2019).

\section{Luzula pallidula Kirschner}

Mezőföld:

9378.1: Bikács-Kistápé „Akalacsi-erdő” M4 (KEVEY 1983: 21).

Luzula forsteri (Sm.) DC.

Villányi-hegység:

0176.1: Kisharsány „Siklósi-völgy” K2 (KEVEY 1990: 91). 


\section{Melica altissima L.}

Jászság:

8686.2: Jászalsószentgyögy „Borsa-erdő” M3 (Kevey \& Urbán ined.: 2017).

Duna-Tisza köze:

9083.1: Hetényegyháza „Nagy-Nyíri-erdő” M4 (Kevey \& Urbán ined.: 2020).

9083.3: Hetényegyháza „Nagy-Nyíri-erdő” M4 (Kevey \& Urbán ined.: 2020).

\section{Melica nutans L.}

Keszthelyi-hegység:

9169.3: Cserszegtomaj „Csóka-kő” K2 (Kevey ined.: 2000).

Mezőföld:

8976.4: Soponya-Nagyláng „Kastély-park” K1a (KEVEY 1988: 99).

\section{Csepel-sziget:}

8779.2: Szigetújfalu „Újfalusi-erdő” J6 (Kevey ined.: 1987).

8779.3: Ráckeve „Silling-erdő” J6 (Kevey ined.: 1988).

8779.4: Szigetújfalu „Újfalusi-erdő” J6 (Kevey ined.: 1987).

8879.1: Ráckeve „Silling-erdő” J6 (Kevey ined.: 1988).

8979.1: Makád „Rókás” J6 (Kevey ined.: 1989).

\section{Melica transylvanica Schur}

Duna-Tisza köze:

9185.1: Nyárlőrinc „Bogárzó-erdő” M4 (Kevey \& Urbán ined.: 2020).

9884.1: Kelebia „Nagy-Kéri-erdő” M4 (Kevey \& Lendvai ined.: 2019).

Körös-vidék:

9193.1: Bélmegyer „Szolga-erdo”” M3 (Kevey ined.: 2002).

\section{Milium effusum $\mathrm{L}$.}

Mezőföld:

8678.4: Martonvásár „Kastély-park” J6 (Kevey 1981: 181).

\section{Molinia coerulea (L.) Moench}

Nyírség:

8596.2: Debrecen-Bánk „Kalánhegyi-tölgyes” M4 (Kevey \& Papp ined.: 2019).

8597.2: Vámospércs „Bagaméri-erdő” M4 (Kevey \& Papp ined.: 2019).

Muscari botryoides (L.) Mill.

Nyírség:

8597.2: Vámospércs „Bagaméri-erdő” M4 (Kevey \& Papp ined.: 2019).

Külső-Somogy:

9372.4: Gamás „Vadéi-erdő” (Ötvös in KEvEY 1995: 49).

Zselic:

9672.4: Kaposvár „Som-hegy” (Horváth J. in KEvEY 1995: 49).

Muscari comosum (L.) Mill.

Nyírség:

8497.3: Debrecen-Haláp „Álló-hegy” M4 (Kevey, Demeter \& Papp ined.: 2019).

8597.2: Vámospércs „Bagaméri-erdő” M4 (Kevey \& Papp ined.: 2019).

Muscari neglectum Guss. ex Ten.

Duna-Tisza köze:

8984.1: Csemő „Szénásteleki-erdő” M4 (Kevey \& Lendvai ined.: 2012).

Neottia nidus-avis (L.) Rich.

Nyírség:

8497.3: Debrecen-Haláp „Álló-hegy” M4 (Kevey, Demeter \& Papp ined.: 2019).

Oenanthe silaifolia M. Bieb.

Körös-vidék:

8796.3: Hencida „Csere-erdő” M3 (Kevey \& Papp ined.: 2017). 


\section{Orchis militaris L.}

Dráva-sík:

9973.2: Szentlőrinc „Aszai-árok: a horgásztó mellett” D2 (Kevey ined.: 2000).

\section{Orchis morio L.}

Körös-vidék:

8796.3: Hencida „Csere-erdő” M3 (Kevey \& Papp ined.: 2017).

\section{Orchis purpurea Huds.}

Mezőföld:

9176.1: Dég „a Kastély-park Őztelek felőli sarkán” J6 (MAJER 1979: 10; KEVEY 1984: 53).

Ornithogalum boucheanum (Kunth) Asch.

Jászság:

8586.3: Alattyán „Berki-erdő” M3 (Kevey \& Urbán ined.: 2018).

\section{Ornithogalum brevistylum Wolfner}

Duna-Tisza köze:

8984.1: Nagykőrös „Nagy-erdő” M4 (Kevey \& Urbán ined.: 2018); Csemő „Szénásteleki-erdő” M4 (Kevey \& Urbán ined.: 2018).

Ornithogalum sphaerocarpum A. Kern.

\section{Keszthelyi-hegység:}

9069.3: Zalaszántó „Kovácsi-hegy” LY4 (Kevey ined.: 1985).

9069.4: Zalaszántó „Tátika” LY2, LY4 (Kevey ined.: 1985).

Bakony:

8872.2: Hárskút „Esztergály-völgy” LY2 (Kevey ined.: 1999).

8373.4: Olaszfalu „Csengő-hegy” LY4 (Kevey ined.: 2017).

Bakonyalja:

8770.4: Kúp „Kúpi-erdő” K1a (Kevey ined.: 1984).

8871.1: Pápakovácsi „Attyai-erdő” K1a (Kevey ined.: 2003).

8871.3: Devecser „Beréndi-erdő” K1a (Kevey ined.: 1992); Devecser „Széki-erdő K1a (Kevey ined.:

2003).

\section{Észak-Zala:}

9167.2: Gyűrűs „Kígyós” K2 (Kevey ined.: 1993).

9168.2: Vindornyaszőlős „Alsó-erdő” K1a (Kevey ined.: 1993).

9267.4: Pölöske „Sohollár” K1a (Kevey ined.: 2014).

Dél-Zala:

9668.2: Iharosberény „Szentpáli-erdő” K2 (Kevey ined.: 1987).

9467.3: Eszteregnye-Obornak „Márki-erdő” K2 (Kevey ined.: 1986).

Mecsek:

9876.1: Pécsvárad „Csiger-tető” LY4 (Kevey ined.: 2017).

Belső-Somogy:

9570.2: Mesztegnyő „Dávodi-tó és Soponyai-tó között” K1a (Kevey ined.: 2001).

9769.3: Szenta „Döbrögi-erdő” K1a (Kevey ined.: 2001).

9771.3: Mike „Patkány-domb” K1a (Kevey ined.: 1989).

Baranyai-dombság:

0075.2: Egerág „Halastói-erdo”” K1a (Kevey ined.: 2012).

0075.3: Bosta „Nagy-erdő” K2 (Kevey ined.: 1994).

Geresdi-dombság:

9777.3: Mecseknádasd „Borvicska-hegy” K2 (Kevey ined. 2017).

Szekszárdi-dombság:

9777.2: Szálka „Rác-erdő” K2 (Kevey ined.: 1989).

\section{Paris quadrifolia L.}

Csepel-sziget:

8779.3: Ercsi „Sziget” J6 (Kevey 2020: 68).

8779.4: Szigetújfalu „Újfalusi-erdő” J6 (KEVEY 2020: 68). 
Phleum phleoides (L.) H. Karst.

Duna-Tisza köze:

9884.1: Kelebia „Nagy-Kéri-erdő” M4 (Kevey \& Lendvai ined.: 2019).

Nyírség:

8497.3: Debrecen-Haláp „Álló-hegy” M4 (Kevey \& Papp ined.: 2019).

Piptatherum virescens (Trin.) Boiss.

Mezőföld:

8977.4: Sárosd „Nagy-erdő” K1a (Kevey ined.: 1997).

Külső-Somogy:

9174.3: Ságvár „Jaba-völgy” K2 (KEvEY 1990: 93).

Platanthera bifolia (L.) Rchb.

Mezőföld:

9278.4: Németkér „Barát-erdő” K1a, L5 (KevEY 1988: 98).

9378.1: Bikács-Kistápé „Akalacsi-erdő” K1a, L5 (KEVEY 1988: 98).

9277.4: Vajta „Nagy-erdő” K1a, L5 (KEVEY 1988: 98).

\section{Poa compressa L.}

Duna-Tisza köze:

8782.1: Csévharaszt „Pótharaszti-erdő” M4 (Kevey \& Urbán ined.: 2020).

8882.3: Táborfalva „Lőtér” M5 (Kevey \& Lendvai ined.: 2012).

\section{Poa nemoralis L.}

Tiszántúl:

8391.4: Hortobágy „Ohat-erdő” M3 (Kevey \& Molnár A. ined.: 2016).

Nyírség:

8596.2: Debrecen-Bánk „Kalánhegyi-tölgyes” M4 (Kevey \& Papp ined.: 2019).

\section{Poa palustris L.}

Tiszántúl:

8391.4: Hortobágy „Ohat-erdo” M3 (Kevey \& Molnár A. ined.: 2016).

Körös-vidék:

8796.3: Hencida „Csere-erdő” M3 (Kevey \& Papp ined.: 2017).

9394.3: Gyula „Kutyahelyi-erdő” M3 (Kevey ined.: 2003).

\section{Poa trivialis L.}

Körös-vidék:

9193.1: Bélmegyer „Szolga-erdo”” M3 (Kevey ined.: 2002).

\section{Polygonatum latifolium (Jacq.) Desf.}

Duna-Tisza köze:

8584.3: Szentmártonkáta „Park-erdő” K1a (Kevey, Lendvai \& Urbán ined.: 2011).

8881.2: Dabas „Turjános” J2 (Kevey ined.: 2016).

8981.2: Kunpeszér „Peszéri-erdo” M4 (Kevey \& Lendvai ined.: 2012).

8881.4: Kunpeszér „Peszéri-erdő” M4 (Kevey \& Lendvai ined.: 2012).

9082.1: Kunbaracs „Búhegyi-erdő” M4 (Kevey ined.: 2014); Kunadacs „Birkajárási-Újerdő” M4 (Kevey ined.: 2015).

9083.1: Hetényegyháza „Nagy-Nyíri-erdő” M4 (Kevey \& Lendvai ined.: 2012).

9083.3: Hetényegyháza „Nagy-Nyíri-erdő” M4 (Kevey \& Lendvai ined.: 2012).

9381.4: Kiskőrös „Szűcsi-erdő” J2 (Kevey ined.: 2015).

9481.1: Kecel „Berek-erdő” J2 (Kevey ined.: 2015).

Tiszántúl:

8391.4: Hortobágy „Ohat-erdő” M3 (Kevey \& Molnár A. ined.: 2016).

Nyírség:

8497.3: Debrecen-Haláp „Álló-hegy” M4 (Kevey, Demeter \& Papp ined.: 2019).

8597.2: Vámospércs „Bagaméri-erdő” M4 (Kevey \& Papp ined.: 2019). 
Polygonatum multiflorum (L.) All.

Mezőföld:

8976.4: Soponya-Nagyláng „Kastély-park” J6, K1a (KEVEY 1988: 98).

Polygonatum odoratum (Mill.) Druce Nyírség:

8497.3: Debrecen-Haláp „Álló-hegy” M4 (Kevey, Demeter \& Papp ined.: 2019).

8597.2: Vámospércs „Bagaméri-erdő” M4 (Kevey \& Papp ined.: 2019).

Schoenoplectus triqueter L.

Szigetköz:

8170.2: Lipót „Harmadik-erdő” J3 (Kevey ined.: 1996).

8171.3: Ásványráró „Halrekesztő” J3 (Kevey ined.: 1996).

8271.2: Győrzámoly „Patkányos” J3 (Kevey ined.: 1997).

8272.1: Nagybajcs „Robinzon-sziget” J3 (Kevey ined.: 1991).

8272.4: Vének „Kolera.sziget” J3 (Kevey ined.: 1998).

Scilla vindobonensis Speta

Sárköz:

9879.1: Baja „Pandúr-sziget” J4, J6 (Kevey ined.: 2019).

Jászság:

8586.3: Alattyán „Berki-erdő” M3 (Kevey \& Urbán ined.: 2018).

Mezőföld:

9176.2: Dég „Kastély-park” J6, K1a (KeVEY 1985: 157).

Scirpoides holoschoenus (L.) Soják

Nyírség:

8497.4: Vámospércs „Jónás-rész” M4 (Kevey \& Papp ined.: 2019).

Secale sylvestre Host

Duna-Tisza köze:

8984.1: Nagykőrös „Csókás-erdő” M4 (Kevey \& Urbán ined.: 2018).

9083.3: Hetényegyháza „Nagy-Nyíri-erdő” M4 (Kevey \& Urbán ined.: 2020).

Sternbergia colchiciflora Waldst. et Kit.

Duna-Tisza köze:

9185.1: Nyárlőrinc „Bogárzó-erdő” M4 (Kevey ined.: 2020).

Stipa borysthenica (Czern. ex Lindem.) Trautv.

Duna-Tisza köze:

9083.3: Hetényegyháza „Nagy-Nyíri-erdő” M4 (Kevey \& Urbán ined.: 2020).

9185.1: Nyárlőrinc „Bogárzó-erdő” M4 (Kevey \& Urbán ined.: 2020).

Stipa capillata L.

Duna-Tisza köze:

9185.1: Nyárlőrinc „Bogárzó-erdő” M4 (Kevey \& Urbán ined.: 2020).

Nyírség:

8497.3: Debrecen-Haláp „Álló-hegy” M4 (Kevey \& Papp ined.: 2019).

\section{Stratiotes aloides L.}

Szigetköz:

8069.4: Mosonmagyaróvár „Parti-erdő” J2 (Kevey ined.: 1988).

\section{Veratrum album L.}

Dráva-sík:

9972.1: Merenye „Meggyes-erdő” J5 (Kevey ined.: 1999).

Wolffia arrhiza (L.) Horkel et Wimm.

Sárköz:

9578.3: Mözs „Vöröskereszt-nádas” (Farkas in KEVEY 1993: 58).

Mohácsi-sziget:

0078.4: Kölked „Macska-lyuk” (KeVEY 1993: 58). 